\title{
Geodynamic evolution of a wide plate boundary in the Western Mediterranean, near-field versus far-field interactions
}

\author{
Laurent Jolivet $^{1, *}$ (D), Thierry Baudin ${ }^{2}$, Sylvain Calassou ${ }^{3}$, Sébastien Chevrot $^{4}$ (D), Mary Ford ${ }^{5}$, \\ Benoit Issautier $^{2}$ (D), Eric Lasseur ${ }^{2}$ (D), Emmanuel Masini ${ }^{6}$, Gianreto Manatschal ${ }^{7}$ (D), Frédéric Mouthereau ${ }^{4}$, \\ Isabelle Thinon ${ }^{2}$ and Olivier Vidal ${ }^{6}$ \\ ${ }^{1}$ Sorbonne Université, UMR 7193 CNRS-UPMC, Institut des Sciences de la Terre Paris, 75005 Paris, France \\ 2 BRGM, GeoResources Division, Orléans, France \\ 3 Centre de recherches de Total, Pau, France \\ ${ }^{4}$ GET-OMP, UMR 5563, Université Paul Sabatier, Toulouse, France \\ 5 CRPG, Université de Lorraine, Nancy, France \\ ${ }^{6}$ ISTERRE, Université Grenoble Alpes, CNRS, Grenoble, France \\ 7 ITES_EOST, UMR 7063, Université de Strasbourg, CNRS, Strasbourg, France
}

Received: 31 March 2021 / Accepted: 28 September 2021 / Publishing online: 20 October 2021

\begin{abstract}
The present-day tectonic setting of the Western Mediterranean region, from the Pyrénées to the Betics and from the Alps to the Atlas, results from a complex 3-D geodynamic evolution involving the interactions between the Africa, Eurasia and Iberia plates and asthenospheric mantle dynamics underneath. In this paper, we review the main tectonic events recorded in this region since the Early Cretaceous and discuss the respective effects of far-field and near-field contributions, in order to unravel the origin of forces controlling crustal deformation. The respective contributions of mantle-scale, plate-scale and local processes in the succession of tectonic stages are discussed. Three periods can be distinguished: (1) the first period (Tethyan Tectonics), from 110 to $35 \mathrm{Ma}$, spans the main evolution of the Pyrenean orogen and the early evolution of the Betics, from rifting to maximum shortening. The rifting between Iberia and Europe and the subsequent progressive formation of new compressional plate boundaries in the Pyrénées and the Betics, as well as the compression recorded all the way to the North Sea, are placed in the large-scale framework of the African and Eurasian plates carried by large-scale mantle convection; (2) the second period (Mediterranean Tectonics), from 32 to $8 \mathrm{Ma}$, corresponds to a first-order change in subduction dynamics. It is most typically Mediterranean with a dominant contribution of slab retreat and associated mantle flow in crustal deformation. Mountain building and back-arc basin opening are controlled by retreating and tearing slabs and associated mantle flow at depth. The 3-D interactions between the different pieces of retreating slabs are complex and the crust accommodates the mantle flow underneath in various ways, including the formation of metamorphic core complexes and transfer fault zones; (3) the third period (Late-Mediterranean Tectonics) runs from $8 \mathrm{Ma}$ to the Present. It corresponds to a new drastic change in the tectonic regime characterized by the resumption of N-S compression along the southern plate boundary and a propagation of compression toward the north. The respective effects of stress transmission through the lithospheric stress-guide and lithosphere-asthenosphere interactions are discussed throughout this period.
\end{abstract}

Keywords: mantle flow / convection / collision / subduction / lithosphere / Mediterranean / back-arc extension / slab retreat / slab tearing / Pyrénées / Betic Cordillera / Rif / Liguro-Provençal Basin / Alboran Sea / Tyrrhenian Sea

Résumé - Évolution géodynamique d'une limite de plaque diffuse en Méditerranée occidentale, interactions à courte et longue distance. Le contexte tectonique actuel de la Méditerranée occidentale, des Pyrénées aux Bétiques et des Alpes à l'Atlas, résulte d'une évolution géodynamique complexe en 3-D impliquant les interactions entre les plaques Afrique, Eurasie et Ibérie et le manteau asthénosphérique sousjacent. Dans cet article, nous présentons une revue critique des principaux événements tectoniques survenus

*Corresponding author: laurent.jolivet@sorbonne-universite.fr 
dans la région depuis le Crétacé supérieur pour discuter les contributions respectives des processus locaux et lointains, dans le but de mieux comprendre les forces contrôlant la déformation crustale. Les contributions respectives des processus à l'échelle du manteau, à l'échelle des plaques et les processus régionaux sont discutées. Trois périodes doivent être distinguées : (1) la première période (Tectonique Téthysienne), de 110 à $35 \mathrm{Ma}$, recouvre toute l'évolution de l'orogène pyrénéen et l'évolution précoce des Bétiques et du Rif, depuis le rifting jusqu'au raccourcissement maximum. Le rifting entre Ibérie et Europe et la formation de nouvelles limites de plaques convergentes et compressives dans les Pyrénées et les Bétiques et la propagation de contraintes compressives jusqu'à la Mer du nord sont placés dans le cadre des plaques Eurasie et Afrique portées par la convection mantellique à grande échelle; (2) la deuxième période (Tectonique Méditerranéenne), de 32 à $8 \mathrm{Ma}$, est plus typiquement méditerranéenne avec une contribution dominante du recul des panneaux lithosphériques plongeants et des flux mantelliques associés. Construction des chaînes de montagnes et ouverture des bassins arrière-arc sont dominés par cette dynamique de retrait et de déchirure des panneaux plongeants et par le flux asthénosphérique qui en résulte. Les interactions 3-D entre les différents morceaux des panneaux plongeants sont complexes et la croÛte accommode les flux mantelliques de façons variées, incluant la formation de metamorphic core complexes et de zones de transfert; (3) la troisième période (Tectonique Tardi-Méditerranéenne) débute à $\sim 8 \mathrm{Ma}$ et se poursuit jusqu'à aujourd'hui. Elle correspond à un nouveau changement drastique de la dynamique de subduction associé à une reprise de la compression N-S au travers de la limite de plaque méridionale et une propagation de la compression vers le nord et l'est. Les effets respectifs de la transmission des contraintes le long du guide de contraintes qu'est la lithosphère et des interactions lithosphère-asthénosphère sont discutés pour chacune de ces trois périodes.

Mots clés : flux mantellique / convection / collision / subduction / lithosphère / Méditerranée / extension arrière-arc / retrait du panneau plongeant / déchirure du panneau plongeant / Pyrenées / Cordillère Bétique / Rif / Bassin LiguroProvençal / Mer d'Alboran / Mer Tyrrhénienne

\section{Introduction: different scales and different periods}

The Mediterranean region is the heir of a former wider ocean, the Neo-Tethys. The Mediterranean mountain belts and post-Eocene back-arc basins result in fine from the convergence of Africa and Eurasia (Dercourt et al., 1986; Ricou et al., 1986; van Hinsbergen et al., 2019). This region has been studied in great detail since more than a century and its tectonic history has been reconstructed since the Triassic (Dercourt et al., 1986, 1993; Ziegler, 1999; van Hinsbergen et al., 2019; Angrand et al., 2020). Subduction dynamics changed around 35-30 Ma in this region, from a typical Tethyan pattern with the formation of mountain belts along the south margin of Eurasia, to a characteristic Mediterranean dynamics with fast slab retreat and formation of tight arcs (Jolivet and Faccenna, 2000). Tight arcs and fast-opening back-arc basins, coeval with the continuing formation of mountain belts near the subduction trench, is indeed a characteristic of the Mediterranean (Malinverno and Ryan, 1986; Royden, 1993; Jolivet et al., 1994; Carminati et al., 1998a; Jolivet et al., 1998; Jolivet and Faccenna, 2000; Wortel and Spakman, 2000; Faccenna et al., 2001a; Spakman and Wortel, 2004; Faccenna et al., 2013b). The Western Mediterranean shows this type of evolution with the addition of a complex 3-D configuration where several orogenic systems (Alps, Pyrénées, Apennines, Maghrebides, Betics) interfere in time and space (Réhault et al., 1984, 1987; Carminati et al., 1998a, 1998b; Faccenna et al., 2001a, 2001b, 2004; Rollet et al., 2002; Vignaroli et al., 2009). Detailed reconstructions of the post-Eocene kinematics are available in the literature (Dewey et al., 1989; Rosenbaum et al., 2002a, 2002b; Schettino and Turco, 2006; Mantovani et al., 2009; van Hinsbergen et al., 2014, 2019; Mantovani et al., 2020;
Romagny et al., 2020) that agree on the first order displacements but differ on the driving mechanisms. The respective influence of slab retreat and extrusion are for instance debated. This 3-D complexity seen in the crust in fact reflects the complexity of slab interactions at depth. A wealth of recent studies across the Africa-Eurasia plate boundary zone, including those of the Orogen project, shed light on these interactions through time. We review in this paper the recent findings with a special attention to the outcome of the Orogen Project and discuss their implications on the various drivers, near-field and far-field, of the orogens and basins of the Western Mediterranean.

\section{Geodynamic context of Western Mediterranean orogens and basins}

Plate movements and deformations are to a first order controlled by the variable degree of coupling between the lithosphere and the asthenospheric mantle convecting underneath (Fig. 1). Plates attached to a subducting lithosphere are the fastest and they are mostly driven by slab pull (Uyeda and Kanamori, 1979; Ricard and Vigny, 1989; Ricard et al., 1989; Conrad and Lithgow-Bertelloni, 2002; Coltice et al., 2019). The role of plumes in these displacements is debated, whether they are a passive response to subduction or an active player (plume push) (Forte et al., 2010; Becker and Faccenna, 2011; Moucha and Forte, 2011; Glisovic et al., 2012; Faccenna et al., 2013a, 2014). This classical question about the respective roles of plume and subducting slabs is possibly not correctly formulated as the sub-lithospheric mantle is an incompressible fluid on geological time scales and any displacement somewhere has to be instantaneously compensated by a displacement somewhere else. It has been proposed that mantle 


\section{ABSOLUTE VELOCITIES (WITH RESPECT TO MANTLE)}

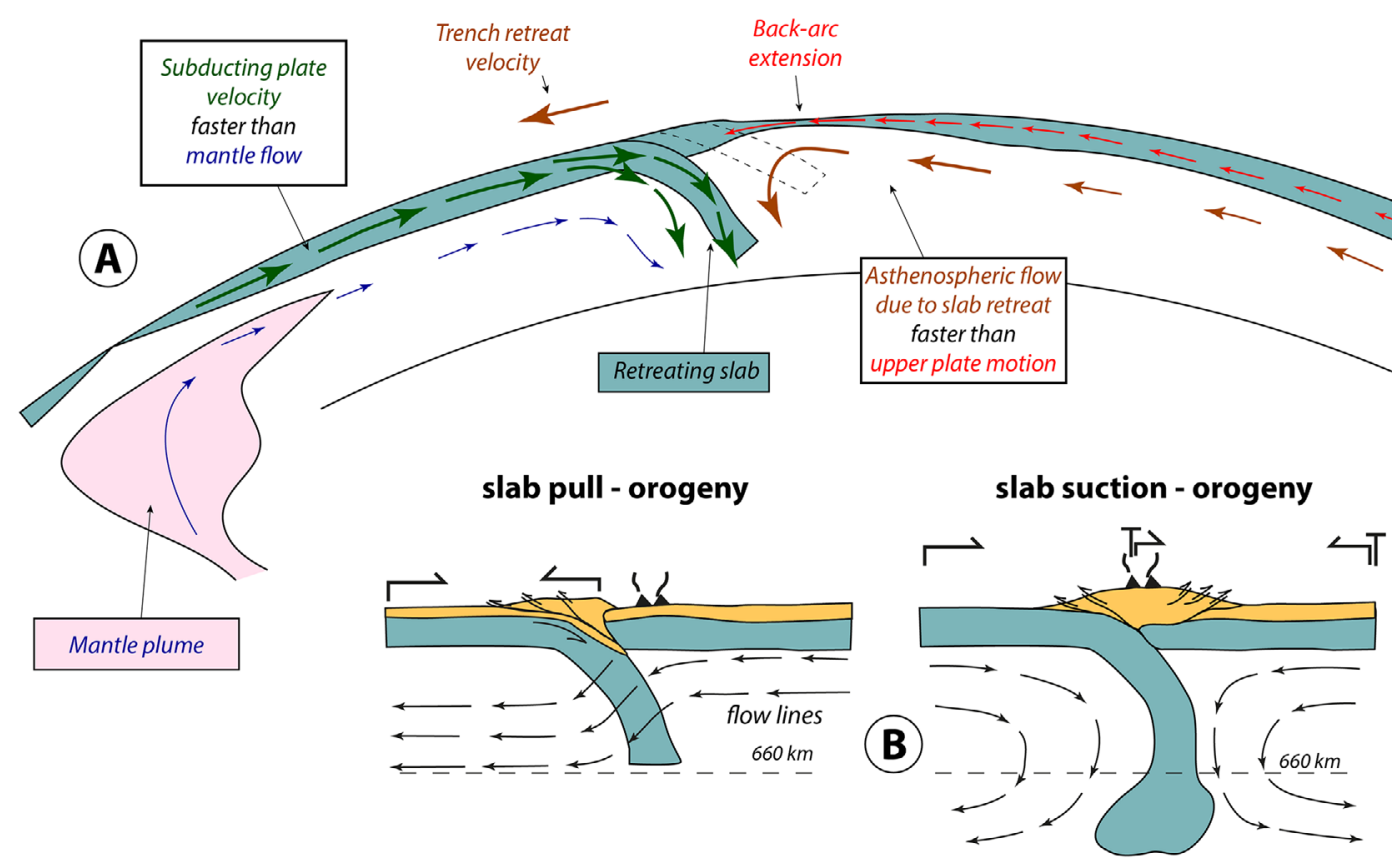

Fig. 1. Plate motion, lithospheric deformation and mantle flow. A. Differential velocities between lithosphere and asthenosphere in plate attached to slabs and overriding plates and associated deformation, after Coltice et al. (2019). B Slab-pull versus slab-suction orogeny after Faccenna et al. (2013a). In slab-pull orogens, the slab is retreating and flow lines in the mantle thus cross the slab, while in slab-suction orogens, the slab is anchored in the lower mantle at the contact between two convection cells.

flow underneath continents, partly due to mantle plumes, can be an active force when it pushes on irregularities of the base of the lithosphere (Stoddard and Abbott, 1996; Alvarez, 2010; Koptev et al., 2015, 2017, 2019). When, instead, continents are carried by plates that are not attached to a subducting lithosphere, their deformation is, on the opposite, largely driven by the mantle flowing underneath and this is particularly the case on the edges of continents above retreating subduction zones (Coltice et al., 2019).

Orogeny is moreover controlled by two types of forces, body-forces and boundary-forces (Molnar and Lyon-Caen, 1988; England and Houseman, 1989). Boundary-forces arise from lithospheric plate interactions, divergence, convergence or strike-slip. Stresses are transmitted through the lithospheric stress-guide over large distances (Elsasser, 1968) but plate motions are also the visible part of mantle convection (McKenzie, 1969). Continents are passively transported on the convective mantle, but they can locally modify the convective regime (Burov and Gerya, 2014; Koptev et al., 2015, and references therein). The complex geometry of plate boundaries can lead to drastic changes in the stress field during convergence and explain the succession of tectonic stages with variable characteristics (Bellahsen et al., 2003). Far-field events can then have direct effects on the dynamics of an orogen in this context.

Body-forces, on the other hand, arise from lateral density contrasts within the lithosphere, in which case they control the surface kinematics and thus the distribution of stresses within the plates, hence interfering with boundary forces (England and Houseman, 1989). For instance, crustal thickening due to shortening leads to an increase of the potential gravitational energy stored within the crust and favors crustal collapse or spreading (Molnar and Lyon-Caen, 1988; England and Houseman, 1989; Platt and Vissers, 1989; Vissers et al., 1995). But crustal shortening is also associated with subduction of the lithospheric mantle, and the slab below the accretionary wedge has an opposite effect to crustal thickening, pulling the topography downward (Faccenna et al., 2013a). Besides, lithospheric thinning due to rifting or delamination also leads to an increase of the gravitational potential energy and thus favors further extension (Bird, 1979, 1991).

The complexity of the interplay of body-forces and boundary-forces can explain the episodic evolution of orogens with, for instance, the interruption of a shortening continuum or modifications of stress regime when the lithospheric root detaches or delaminates, setting a new geodynamic framework. This already complex interactions can be further modulated by the variable thickness and rheology, thus the thermal age of the continental lithospheres involved in orogenic processes (Burov, 2011; Mouthereau et al., 2013). Such complexity becomes even more important in 3-D when the thickened crust can escape laterally as observed in the India-Asia collision zone with the lateral eastward escape of the thick Tibetan crust (Molnar and Tapponnier, 1975; Tapponnier and Molnar, 1976; Tapponnier et al., 2001; Royden et al., 2008; Yin, 2010). When a continent clogs a subduction zone, it can induce a detachment or a tear of the subducting slab, which can have drastic consequences on the geometry of convection underneath and on crustal deformation (Capitanio, 2014; Sternai et al., 2014; Capitanio et al., 2015; Sternai et al., 2016). The case of the Mediterranean is an 
example of this behavior. The collision of Arabia with Eurasia induced slab tearing in the Late Eocene-Early Oligocene and a change in the subduction regime with fast roll-back and the opening of back-arc basins (Le Pichon, 1982; Jolivet and Faccenna, 2000; Faccenna et al., 2006; Schildgen et al., 2014).

Slab retreat is a major ingredient of Mediterranean geodynamics. It occurs when the velocity of subduction (understood here as the length of lithosphere sinking into the asthenosphere per time unit) outpaces the velocity of convergence, leading to a retreat of the trench with respect to the overriding plate (Dewey, 1980; Malinverno and Ryan, 1986; Royden, 1993; Funiciello et al., 2003). It generally corresponds to the passive sinking of the subducting plate in the mantle under its own weight. Slab retreat has some very close similarities with delamination in the sense of Bird (1979), as exemplified by the evolution of the Apennines (Jolivet et al., 1998; Piana Agostinetti and Faccenna, 2018) or the Gibraltar Arc system (Angrand et al., 2020; Daudet et al., 2020).

Combining the effects of intra-lithospheric stresses and interactions between convection and lithospheric deformation, Faccenna et al. (2013a) have proposed two end-members for orogeny (Fig. 1). Slab-pull orogens are driven by a retreating slab confined in the upper mantle and they are mostly asymmetrical (Western Alps), whereas slab-suction orogens develop above a slab penetrating the lower mantle, associated with surge of mantle upwelling leading to more symmetrical orogens in general (Himalaya and Tibet). In this interpretation, the first order driver of orogeny is mantle convection. Whether stresses controlling the deformation of continents are transmitted through the lithospheric stress-guide or result from coupling with the convective mantle is thus a difficult problem in 3-D when continental margins and plate boundaries have complex pre-orogenic geometries, like in the Mediterranean realm. However, smaller orogens, such as the Pyrénées, where finite convergence is low (maximum $200 \mathrm{~km}$ ) do not easily fit in this two end-member model because mantle flow will have a limited effect during shortening and tectonic inheritance of the pre-orogenic rift crustal scale structures is a major ingredient.

The view emphasizing slab retreat as the first order engine of back-arc rifting is, however, not shared by all workers. Alternative mechanisms have been proposed. Doglioni et al. (2002) put forward internal deformation of the overriding plate, independent of slab retreat, for the Aegean extension. Armijo et al. (1999) argue in favor of rigid extrusion as the main driver of the formation of the North Anatolian Fault and coeval Aegean extension. A recent synthesis by Mantovani et al. (2020) also argues in favor of extrusion to explain extension in the Central and Western Mediterranean. The reader is referred to these papers to read more about these alternative models and we deliberately place our discussion in the framework of the school of thought interpreting back-arc basins of the Mediterranean region as the result of slab retreat.

Within this large-scale framework, the Pyrénées (Fig. 2) are a small late Cretaceous to Cenozoic orogen, partly frozen in an early stage of its development, surrounded by oceanic domains, either pre-orogenic (the Cretaceous oceanic domain of the Bay of Biscay) (Jammes et al., 2010b; Chevrot et al., 2018; Lescoutre and Manatschal, 2020) or post-orogenic (the Oligo-Miocene Liguro-Provençal Basin and Algerian Basin). This orogen results from the convergence between Iberia and
Europe and on a larger scale from the Africa-Eurasia convergence (Roure et al., 1989; Choukroune et al., 1990; Vergés et al., 1995, 2002; Mouthereau et al., 2014; Ford et al., 2016; Chevrot et al., 2018; Wehr et al., 2018), and it developed together with neighboring orogens such as the Alps, the Iberian Range or the Betic-Rif chain. It is abruptly interrupted in the east where it gives place to the Gulf of Lion passive margin formed during the rifting of the Liguro-Provençal back-arc basin (Réhault et al., 1984; De Voogd et al., 1991; Gorini et al., 1993, 1994; Pascal et al., 1993; Mauffret et al., 1995; Gueguen et al., 1998, Guennoc et al., 2000; van Hinsbergen et al., 2014; Jolivet et al., 2020). The tectonic history of the Pyrénées and, at a larger scale, the Western Mediterranean orogens and basins, from pre-orogenic rifting to post-orogenic extension, thus results from complex 3-D interactions between Africa, Iberia, Europe and the asthenospheric mantle convecting underneath and is thus key to better understand the interplay between forces created by relative plate motion and those due to mantle convection. This paper is a review of these interactions at different scales (near-field $v s$ far-field) through time and of the different models proposed so far, in order to extract the main controlling parameters for each period and the triggers of the main changes, inception of rifting in the early Cretaceous, convergence in the late Cretaceous, slab retreat at the end of Eocene and renewed compression in the late Miocene.

\subsection{Present-day kinematics}

The Western Mediterranean basins belong to a series of back-arc regions formed since the Eocene-Oligocene transition in the Mediterranean region, from the Aegean Sea in the east to the Alboran Sea in the west (Malinverno and Ryan, 1986; Jolivet and Faccenna, 2000). The physiography of the Mediterranean region is essentially shaped by this episode of back-arc extension and dispersion of former mountain belts now forming archipelagos, such as the Cyclades or the islands offshore Tuscany (Jolivet et al., 1998, 2008; Ring et al., 2010; Faccenna et al., 2014). While this dynamics is still active in the Eastern Mediterranean region with extension in the Corinth or Western Anatolian rifts (Armijo et al., 1999; Ford et al., 2007; Rohais et al., 2007; Aktug et al., 2009; Taylor et al., 2011; Ford et al., 2017; Gawthorpe et al., 2018), the Western Mediterranean is for the time being mainly under compression (Deverchère et al., 2003; Billi et al., 2011; Faccenna et al., 2014; Medaouri et al., 2014; d'Acremont et al., 2020). The transition from back-arc extension to N-S compression started some $8 \mathrm{Ma}$ ago and progressively invaded the whole Western and Central Mediterranean, including the South Tyrrhenian Sea, probably very recently (Jolivet et al., 2006; Meijninger and Vissers, 2006; Jolivet et al., 2008; Billi et al., 2011; Augier et al., 2013; Do Couto et al., 2014, 2016; Zitellini et al., 2019; d'Acremont et al., 2020). Whether the Gibraltar and Calabria subductions are still active or not is a debated question (Gutscher et al., 2002; 2017), the stress regime has, however, certainly changed to mostly compressional since the Late Miocene. This can be illustrated by the distribution of focal mechanisms of earthquakes (Fig. 3) showing mostly reverse fault-type earthquakes along the northern coast of Africa and north of Sicily (Meghraoui et al., 1996; 


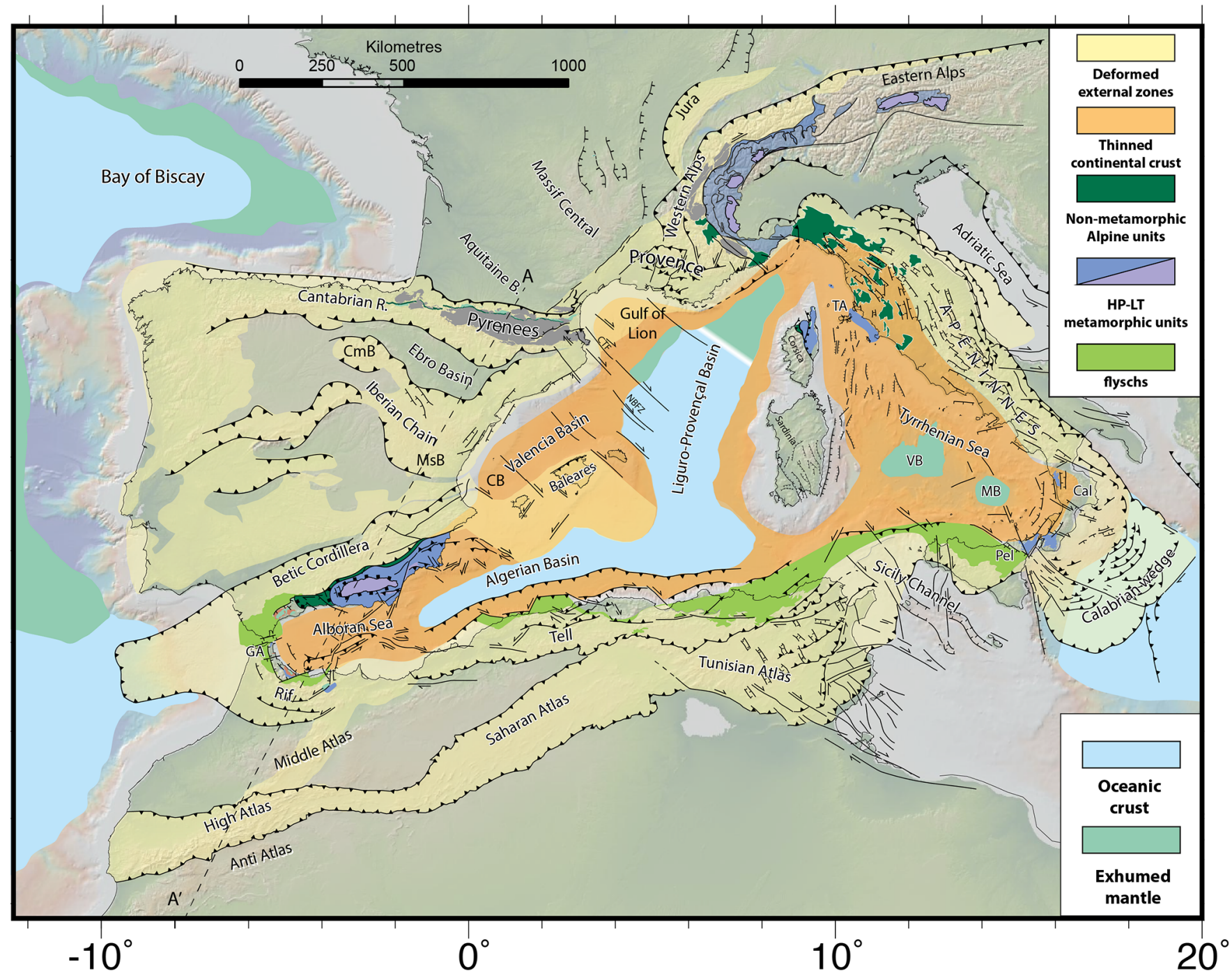

Fig. 2. Tectonic context of the Western Mediterranean region. AA': lithospheric-scale section shown on Figure 22; CB: Columbrets Basin; CmB: Cameros Basin; MsB: Maestrat Basin.

Deverchère et al., 2003; Medaouri et al., 2014). Extension, however, is still active within the Apennines, especially in the regions of highest elevation (Lavecchia, 1988; D'Agostino et al., 1998; Collettini and Barchi, 2002; Ghisetti and Vezzani, 2002; Collettini and Barchi, 2004) and also in the internal zones of the internal part of the Southern French-Italian Alps (not show on Fig. 3 because magnitudes are too small, only symbolized by a double-headed arrow) (Sue et al., 1999; Calais et al., 2002; Delacou et al., 2004; Walpersdorf et al., 2018). The present-day stress pattern is quite simple, as shown by several types of indicators (focal mechanisms, in-situ measurements, boreholes) in the World Stress Map (Zoback, 1992; Heidbach et al., 2018) with $\sigma_{\mathrm{hmax}}$ trending NNE-SSW in most regions whatever the local tectonic regime, extensional, compressional or strike-slip (Fig. 4). At the scale of the Mediterranean, present-day displacements measured with space geodesy (Fig. 5) are clearly dominated by the fast counterclockwise rotation of Anatolia and the faster displacement of the Hellenic Arc (McClusky et al., 2000; Reilinger et al., 2006; Serpelloni et al., 2007; Reilinger et al., 2010;
Faccenna et al., 2014). When zooming on the Western Mediterranean (Fig. 5), two regions are moving significantly with respect to Eurasia, the backbone of the Italian peninsula and Sicily on the one hand, moving northward or northnortheastward, and the Gibraltar Arc and part of northwest Africa, moving westward, on the other hand (Serpelloni et al., 2007; Pérouse et al., 2012). This recent kinematic regime was established progressively from the Late Miocene.

\subsection{Mediterranean orogens and back-arc basins}

The Pyrénées essentially formed during the late Cretaceous and Eocene and were partly dismantled in their eastern part after the Eocene (Choukroune, 1989; Choukroune et al., 1990; Mouthereau et al., 2014; Teixell et al., 2018; Espurt et al., 2019; Jolivet et al., 2020). They are exemplary of these complex interactions of boundary forces and body forces, with a transition from post-rift to contraction at $\sim 84 \mathrm{Ma}$, a direct consequence of the relative motion of Africa and Eurasia (Fig. 6). Some forces are locally originated (near-field) or find 


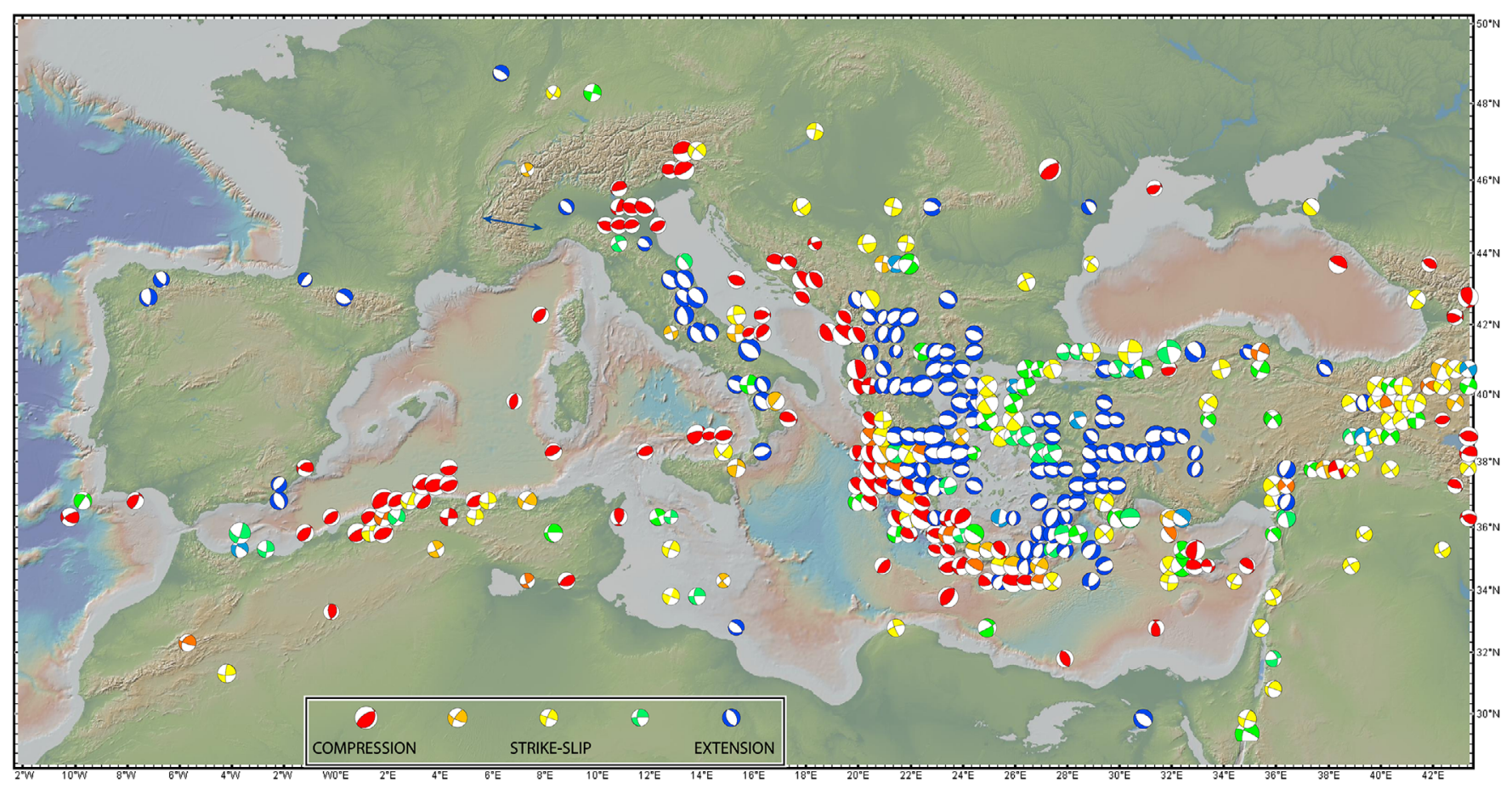

Fig. 3. Focal mechanisms of earthquakes in the Mediterranean region after Faccenna et al. (2014) showing the compressional context of the Western Mediterranean. The blue double-headed arrow shows the direction of extension recorded by GPS measurements in the southern part of the Alps, after Walpersdorf et al. (2018).

their source in distant processes (far-field). These various forces can be described as a function of scale (Fig. 7).

The Mediterranean region is a puzzle of basins and orogens (Figs. 6 and 8) sharing a common timing. The Eastern Mediterranean oceanic crust is the last remnant of the former Tethys Ocean (Dercourt et al., 1986; Frizon de Lamotte et al., 2011; van Hinsbergen et al., 2019) (Fig. 9). Its age is debated, with large variations from the Late Cretaceous to the Paleozoic (Dercourt et al., 1986; Stampfli and Borel, 2002; Frizon de Lamotte et al., 2011; Granot, 2016; van Hinsbergen et al., 2019; Tugend et al., 2019). We consider in this paper an early to Middle Jurassic age for the Ionian basin after Late Triassic to early Jurassic rifting based on the work of Tugend et al. (2019). From the Late Cretaceous, the overall convergence of Africa and Eurasia led to the formation of mountain belts above northdipping subduction zones (Dewey et al., 1989; Rosenbaum et al., 2002a, Rosenbaum et al., 2002b) except in the Alps where subduction was toward the south (Dercourt et al., 1986; Handy et al., 2010; Schmid et al., 2017). In the Eastern Mediterranean, the Hellenides and Taurides formed above the subduction of the Vardar and Pindos Oceans and intervening continental blocks, the so-called Pelagonian and Apulian paleogeographic domains (Aubouin, 1959; Aubouin et al., 1962; Blake et al., 1981; Bonneau and Kienast, 1982; Dercourt et al., 1986; Ricou et al., 1986). The Alps and Carpathians formed above the south-dipping subduction of the Ligurian and Valais oceanic domains below Apulia (Schmid et al., 1997; Oberhänsli et al., 2004; Schmid et al., 2004, 2008; Handy et al., 2010; Schmid et al., 2017). A classical interpretation is that the Western Mediterranean orogens (Fig. 10) derive partly from the northward subduction of the Mesozoic oceanic lithosphere of the Ionian Sea underneath the so-called
AlKaPeCa (from Alboran, Kabylies, Peloritani, Calabria) block (Fig. 6) and the southward subduction of a small partly oceanic domain sandwiched between Europe and the AlKaPeCa block (Bouillin et al., 1986; Michard et al., 2002; Chalouan et al., 2008; Leprêtre et al., 2018). Vergés and Fernandez (2012) however, proposed an alternative interpretation with two subduction zones with opposite dip separated with a transform fault. A solution intermediate between Michard et al. (2002) and Vergés and Fernandez (2012) was proposed in the recent reconstructions of Romagny et al. (2020). The initial position in the Western Mediterranean domain (its distance from Iberia) is, however, debated and Daudet et al. (2020) place it closer to Iberia than previously published models. The transition in space toward the Alps is unclear because a large part of this system is now buried below the passive margin of the Gulf of Lions and deformed by the Oligo-Miocene Liguro-Provençal back-arc basin (Fig. 2).

From 30-35 Ma, subduction dynamics abruptly changed and all subduction zones started to retreat, forming the Aegean Sea, Liguro-Provençal Basin and Alboran Sea extensional basins in the overriding plate (Figs. 6 and 10), thus dispersing the former mountain belts and forming metamorphic core complexes such as the Cyclades, the Tuscan Archipelago or the Sierra Nevada (Lonergan and White, 1997; Carminati et al., 1998a; Jolivet et al., 1998; Jolivet and Faccenna, 2000; Wortel and Spakman, 2000; Faccenna et al., 2001a; Rosenbaum et al., 2002a; Schettino and Scotese, 2002; Faccenna et al., 2004; van Hinsbergen et al., 2014; Jolivet et al., 2016b). The detailed reconstructions produced by Romagny et al. (2020) in the framework of the Orogen project illustrate this evolution for the Western Mediterranean (Fig. 10). Above these retreating subduction zones, slab-pull-type orogenic wedges (Faccenna 

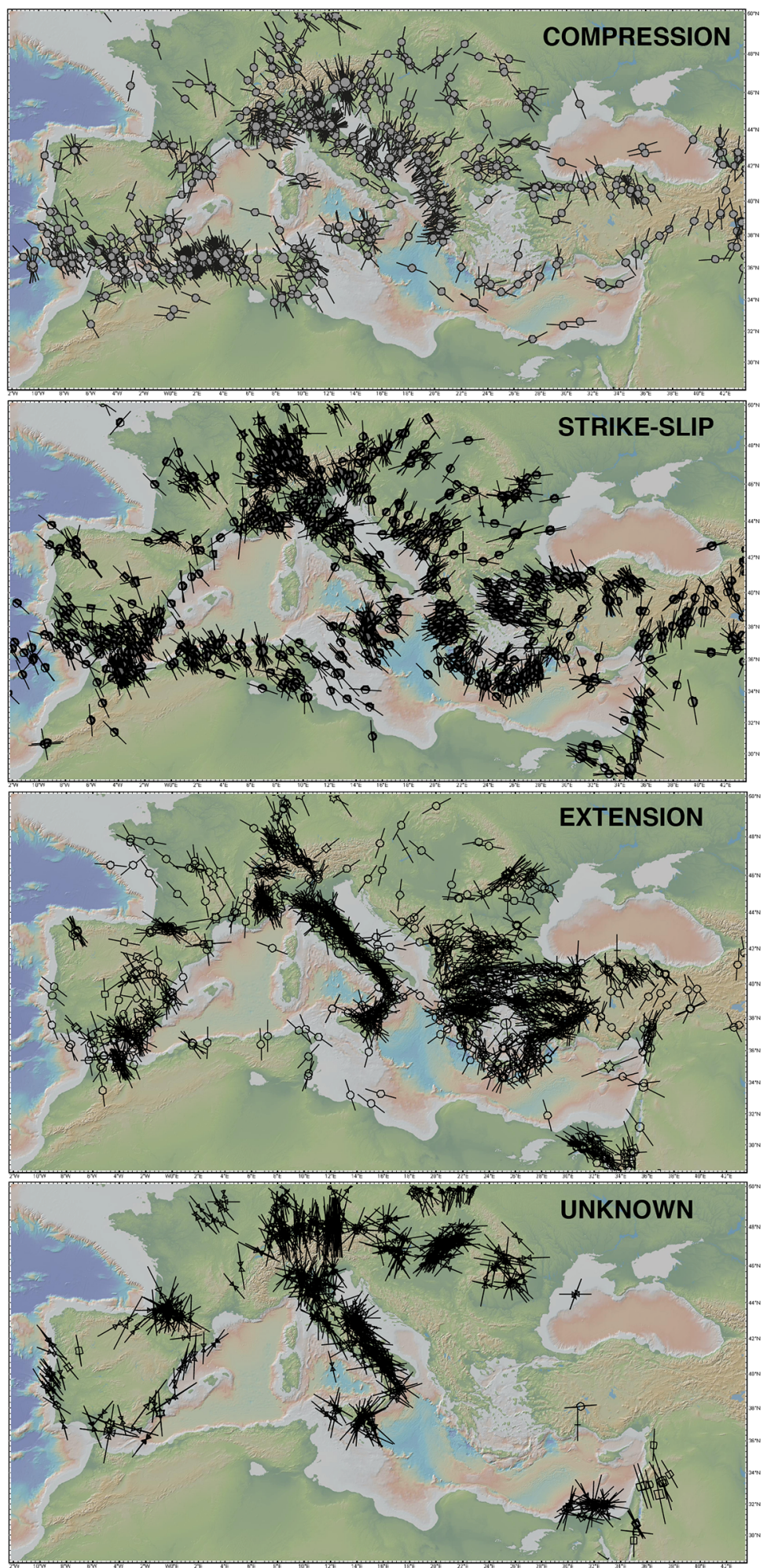

\section{Focal mechanisms}

Borehole breakouts

Drilling-induced fractures

Overcoring

Hydro-fractures

Geological indicators

Fig. 4. Extracts of the World Stress Map for the Mediterranean region (Heidbach et al., 2018) showing the NNW-SSE direction of the main horizontal compression in the Western Mediterranean region and surroundings. Whatever the deformation regime (extension, compression or strike-slip) $\sigma_{\text {hmax }}$ always show the same constant trend. 


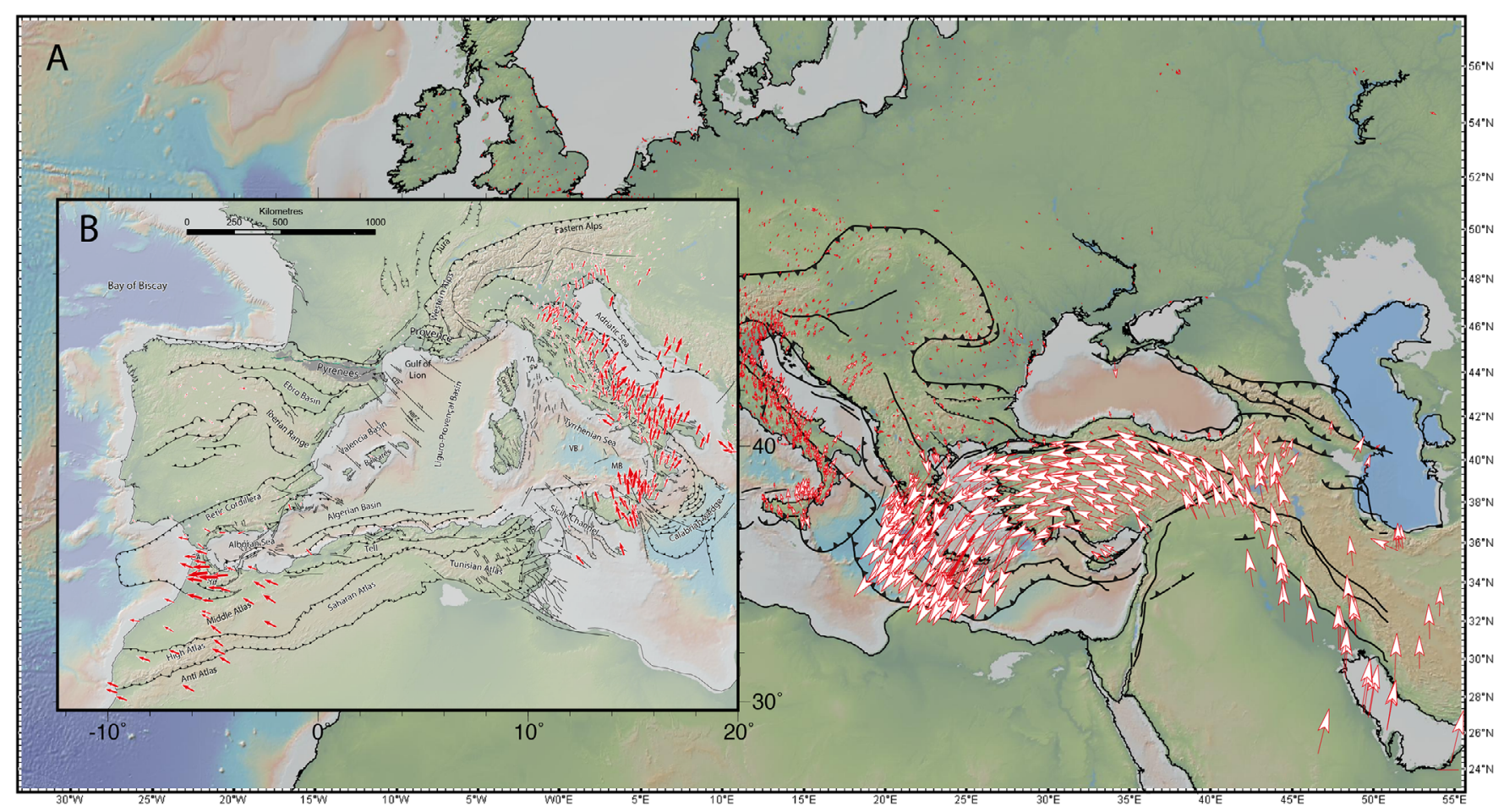

Fig. 5. Current displacements in the Mediterranean region (A) based on GPS measurements: data from Nevada Geodetic Laboratory database and from Faccenna et al. (2014). B. Zoom on the Western Mediterranean region.

et al., 2013a) continued to form by progressive accretion of external zones while the orogenic crust was then thinned in the back-arc domains (Jolivet et al., 1994, Jolivet et al., 1998; Jolivet and Brun, 2010). The Apennines, the Peloponnese and Cretan thrust faults formed in this context while the Tyrrhenian Sea and the Aegean Sea were opening (Jolivet et al., 1994, Jolivet et al., 1998, Jolivet et al., 2003, Jolivet et al., 2013). Similarly, the Betic-Rif arc was formed while the Alboran Sea was opening in the overriding plate (Platt and Vissers, 1989; Comas et al., 1992; Platt, 1993; Martinez-Martinez and Azañon, 1997; Comas et al., 1999; Platt et al., 2003b, Platt et al., 2013; Crespo-Blanc et al., 2016).

This post-35 Ma evolution was associated with large displacements and rotations of crustal blocks, amounting to $800 \mathrm{~km}$ eastward motion for the present-day Calabrian arc, for instance, above the retreating Ionian slab and a minimum of $400 \mathrm{~km}$ westward for the Gibraltar arc (Dewey et al., 1989; Rosenbaum et al., 2002a; van Hinsbergen et al., 2014; Romagny et al., 2020). The nature of the retreating slab, however, is different in the two cases. The slab subducting underneath Calabria is oceanic while that underneath Gibraltar is probably mostly continental. The Oligocene and Miocene geodynamic evolution of this region is thus characterized by the concomitant formation of mountain belts above retreating slabs (slab-pull orogens) and back-arc rifting in the overriding plate, with large displacements of the subducting slab and thus fast movements in the asthenosphere underneath (Barruol and Granet, 2002; Lucente et al., 2006; Buontempo et al., 2008; Jolivet et al., 2009; Salimbeni et al., 2018).

Back-arc rifting, however, did not evolve as a continuum and salient periods must be noticed (Carminati et al., 1998a; Faccenna et al., 2001b, Faccenna et al., 2003). After the first rifting at the turn of the Eocene and Oligocene, the basins opened widely until the $\mathrm{AlKaPeCa}$ block collided with the north African margin at about 20-15 Ma (Leprêtre et al., 2018; Romagny et al., 2020). From then on, the retreating slab was divided in two parts, one retreating eastward to form the Tyrrhenian Sea and one retreating westward to form the Algerian Basin and the Alboran Sea (Carminati et al., 1998a; Wortel and Spakman, 2000; Spakman and Wortel, 2004). These changes are associated with slab tears at depth. In the Western Mediterranean, the geodynamic context changed once more around $8 \mathrm{Ma}$ when north-south compression resumed in the Betics and the present-day compressional reworking of the North African passive margin was set (Billi et al., 2011). Active compression is also observed along the southern margin of France in the region of Nice (Walpersdorf et al., 2018).

\subsection{The Iberia-Europe plate boundary in this context}

In this large-scale context, the Pyrénées (Fig. 11) formed by the inversion of a system of Early Cretaceous intracontinental rifts where sub-continental mantle was exhumed by hyper-extension (Lagabrielle and Bodinier, 2008; Lagabrielle et al., 2010; Jammes et al., 2010b; Clerc et al., 2012; Tugend et al., 2014; Teixell et al., 2018). High-temperature and low-pressure (HT-LP) metamorphism of the Internal Metamorphic Zone (IMZ) of the North Pyrenean Zone (Fig. 11) in Early Cretaceous syn-rift deposits is associated with hyper-extension and mantle exhumation (Ravier, 1959; Kornprobst and Vielzeuf, 1984; Goldberg and Leyreloup, 1990; Lagabrielle and Bodinier, 2008; Clerc et al., 2015b; Chelalou et al., 2016; Clerc et al., 2016; Ducoux et al., 2019). The rifted area goes beyond the Pyrénées and similar inverted 


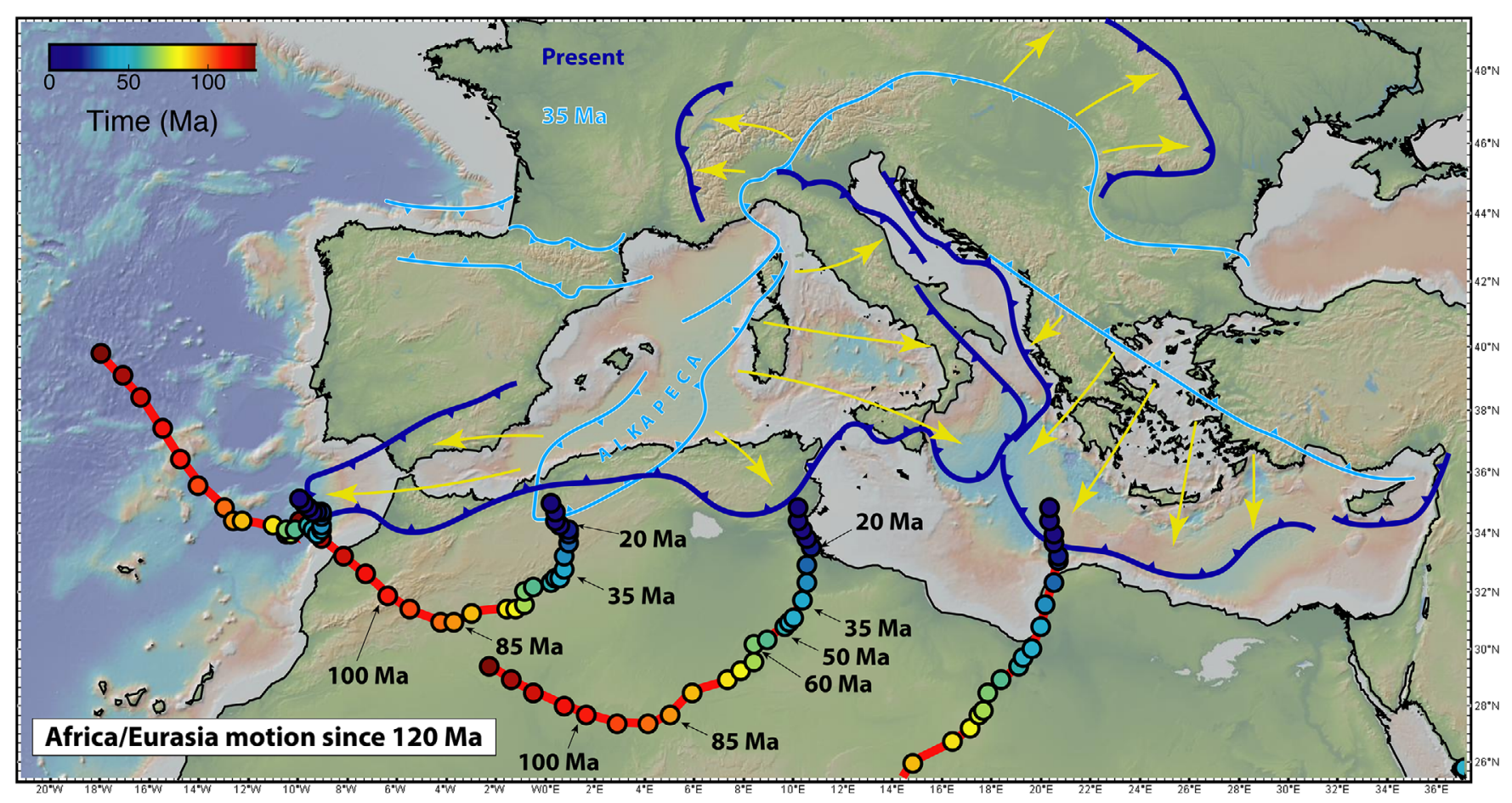

Fig. 6. Africa motion relative to Eurasia and the timing of the successive periods discussed in the paper. Positions of the main trenches and thrusts at $35 \mathrm{Ma}$ and at present and schematic displacements in between.

rifts, the Cameros and Maestrat Basins (Fig. 2), can be found further south within the Iberian chain south of the Ebro Basin (Roca and Guimerà, 1992; Salas and Casas, 1993; Salas et al., 2001; Canérot, 2016; Etheve et al., 2018; Rat et al., 2019). The southwestern part of the Valencia Basin, the Columbrets Basin, is also one of those preserved early rifts (Etheve et al., 2018). Similar rifts are probably hidden below the Gulf of Lion passive margin, as suggested by the Late Cretaceous K-Ar metamorphic age of Paleozoic metasediments recovered at drill hole GLP2 (Fig. 11) (Guennoc et al., 2000) and were overprinted by back-arc extension.

Shortening started in the Late Cretaceous, at around $84 \mathrm{Ma}$ and continued until the Late Eocene on the northern side of the Pyrénées and until the Early Miocene on the southern side (Mouthereau et al., 2014; Bosch et al., 2016; Labaume et al., 2016; Teixell et al., 2018). This early setting of compressional conditions is also recorded in the Betics (Vergés and Fernàndez, 2012; Daudet et al., 2020). The post-orogenic phase, not to be confused with post-orogenic extension that formed the Gulf of Lion rift, started at around $23 \mathrm{Ma}$ and lasted until $12 \mathrm{Ma}$ with the draping of large alluvial fans at high altitude on top of the northern and southern wedges (Babault et al., 2005; Bernard et al., 2020). Shortening was accommodated by a series of north-dipping and south-dipping thrusts involving the basement in the North Pyrenean Zone and the Axial Zone and mainly the cover in the South Pyrenean Zone above the Triassic evaporites decollement (Choukroune, 1989; Choukroune et al., 1990; Mouthereau et al., 2014; Teixell et al., 2018; Espurt et al., 2019; Grool et al., 2019; Jourdon et al., 2020). The main shortening was accommodated by the northward underthrusting of the Iberian crust and lithospheric mantle below the European lithosphere. The period spanning the late Lutetian and the Bartonian, between 43 and $37 \mathrm{Ma}$, is a turning-point in the style of shortening across the belt (Waldner et al., 2019). Waldner et al. (2019), using compiled thermochronological data, show that, before $40 \mathrm{Ma}$, shortening was distributed across the belt and the maximum exhumation was recorded in the North Pyrenean Zone, while, after $40 \mathrm{Ma}$, north-dipping thrusts accommodated the thickening of the Iberian crust and exhumation migrated southward. The temporal changes in the style of shortening further highlights the accretion of different portions of the rifted margin (Jourdon et al., 2019; Ternois et al., 2021). Structural sections across the belt and seismic profiles show this underthrusting below most of the belt (Vergés et al., 1995, Vergés et al., 2002; Chevrot et al., 2018; Teixell et al., 2018; Espurt et al., 2019) (Fig. 11). The same sections also show the presence of mantle bodies exhumed in the early Cretaceous by hyper-extension, high in the present-day crust of the North Pyrenean Zone (Wang et al., 2016). This orogenic structure totally disappears below the eastern Pyrénées where the Moho appears flat and shallows eastward toward the Gulf of Lion passive margin (Chevrot et al., 2018; Diaz et al., 2018) (Fig. 11A, insert). This striking change has been diversely interpreted, even within the Orogen project, either as a major difference in the pre-orogenic template of the belt (Chevrot et al., 2018) or as an effect of post-orogenic extension during back-arc rifting (Jolivet et al., 2020) (Fig. 11). Early foreland basins have formed on the southern (Ebro Basin) and northern (Aquitaine Basin) sides of the belt. The early internal parts of these two basins are now integrated in the belt, especially in the North Pyrenean Zone as Late Cretaceous flysch-type 

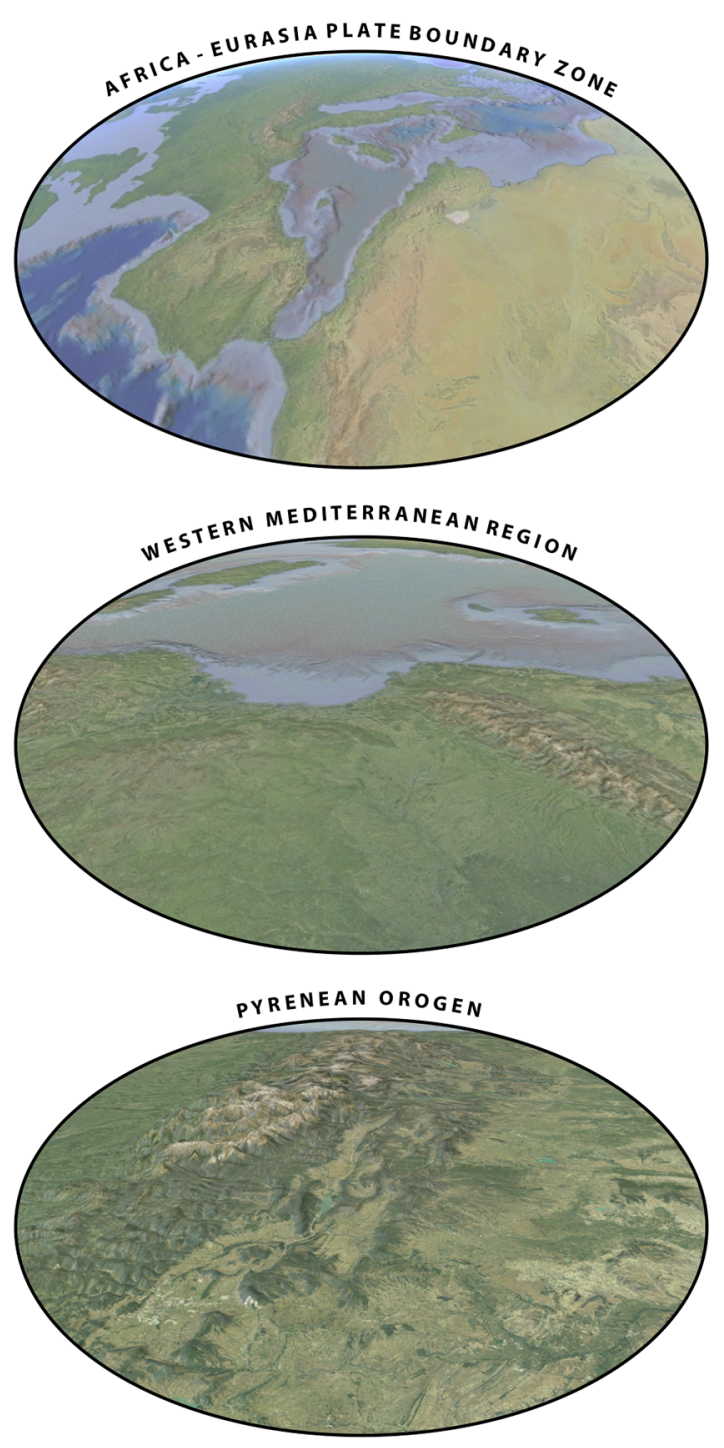

Eurasia / lberia / Africa relative kinematics

Stress transmission through lithospheric stress-guide

Large-scale convection

Influence of slab retreat after $\sim 35 \mathrm{Ma}$

Associated asthenospheric flow

Lateral variations of thickness and density

Thermal structure and history

Structural inheritance

Fig. 7. The different scales and types of forces driving the tectonic evolution of the Western Mediterranean region.

formations (Muñoz, 1992, Muñoz, 2002; Vergés et al., 2002; Ford et al., 2016; Angrand et al., 2018; Grool et al., 2018; Espurt et al., 2019). The basins have then propagated northward and southward.

The transition toward the post-orogenic period is well recorded in Languedoc where syn-tectonic basins formed in a left-lateral transpressional context in the Priabonian during the formation of the West European Rift System, before back-arc extension took over at the end of the Eocene (Séranne, 1999; Séranne et al., 2021). Jolivet et al. (2020) proposed that backarc extension in the Gulf of Lion impacted the eastern part of the range through basal erosion and removal of the upper mantle and lower crust by the asthenospheric flow due to slab retreat. The impact of asthenosphere dynamics beneath the range had already been used as a driver for the late Neogene uplift period around $10 \mathrm{Ma}$ by Gunnell et al. (2009), see also Calvet et al. (2020) or Huyghe et al. (2020). The active extension observed today in the Western Pyrénées seems caused by the juxtaposition of crustal blocks with contrasted density and does not necessarily imply that the system is under extensional boundary conditions (Souriau et al., 2014; Fillon et al., 2021).

\subsection{Some key-dates}

This short review highlights some key-dates in the evolution of the Western Mediterranean region (Figs. 9 and 12). (1) The early Cretaceous is the period of distributed rifting within Iberia and across the Iberia-Europe boundary zone, (2) the Late Cretaceous sees the first shortening in the Pyrénées, but also in the Alps and the Betics, (3) the Eocene is the climax of shortening, but also of formation of highpressure and low-temperature (HP-LT) metamorphic complexes in the continental units of the Alps, Alpine Corsica or the Betics and Kabylies, (4) the end of the Eocene (Priabonian) records the effects of the West European Rift System, (5) from the Oligocene to the early Late Miocene back-arc basins forming above fast retreating slabs and the Eastern Pyrénées are 


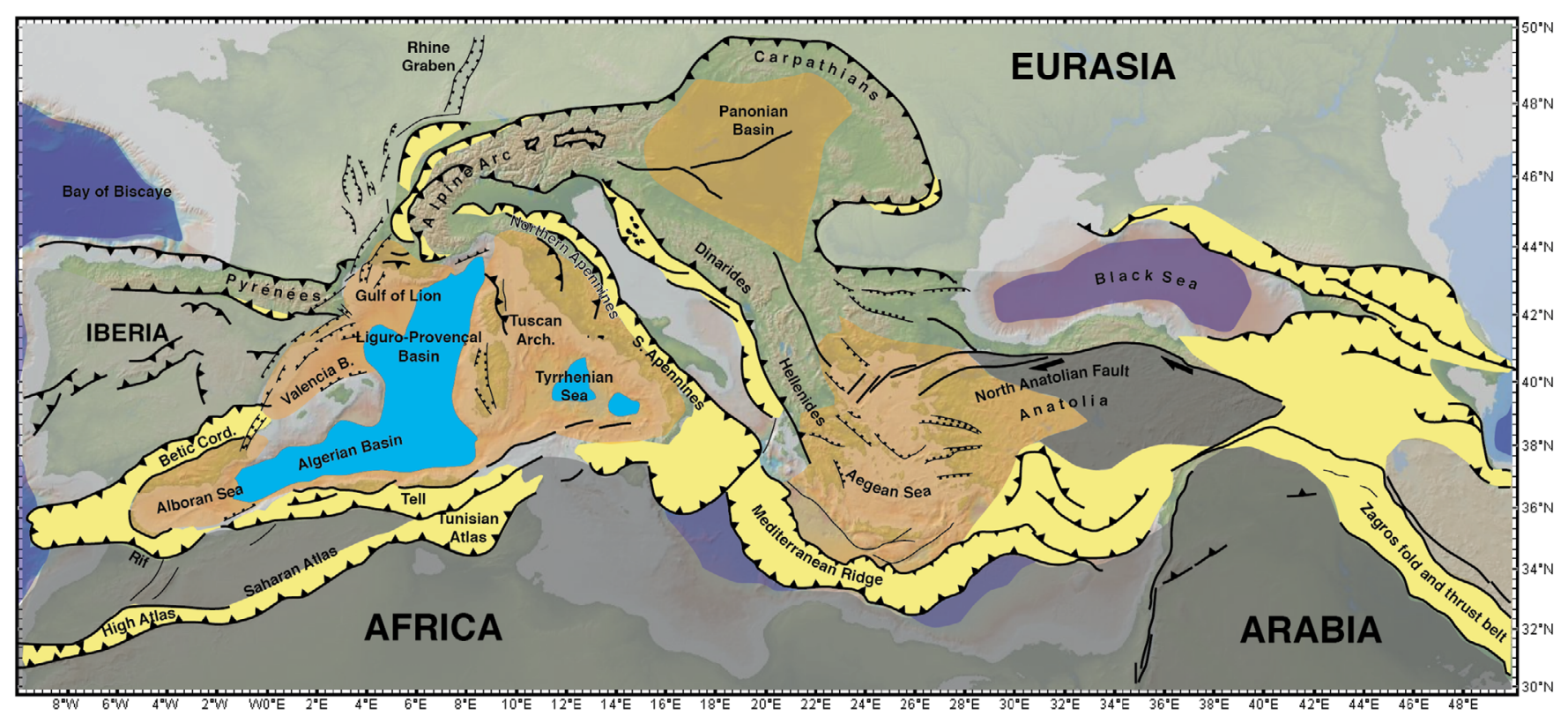

Fig. 8. Tectonic context of the Mediterranean region. Violet: Mesozoic oceanic crust; blue: Cenozoic oceanic crust and/or exhumed mantle; orange: areas affected by Neogene post-orogenic extension.

dismantled during the rifting of the Gulf of Lion, (6) at around $20-15 \mathrm{Ma}$ an episode of tearing separates the retreating slab in two parts, leading to the formation of the Alboran and Tyrrhenian Seas, (7) from the Late Miocene onward north-south compression takes over and the extended orogens are shortened again.

This timing finds echoes in the French-Italian Alps where the Eocene is the major period of formation of blueschists and eclogites in the internal zones and the early Oligocene is characterized by an acceleration of westward thrusting in the external zones (Oberhänsli et al., 2004; Ford et al., 2006; Bousquet et al., 2008; Bellahsen et al., 2014; Bellanger et al., 2014). The timing is also partly similar in the Eastern Mediterranean where the Cycladic Blueschists form in the Eocene, the Aegean Sea back-arc basin starts to rift around 35-30 Ma above the retreating Hellenic slab and a major episode of slab tearing starts at about 15-20 Ma (Bonneau and Kienast, 1982; Maluski et al., 1987; Wijbrans and McDougall, 1988; Wijbrans et al., 1993; van Hinsbergen et al., 2005; Jolivet et al., 2013, Jolivet et al., 2015b). At a larger scale, the timing of the Africa-Eurasia convergence zone also shows the same phases, early Cretaceous extension, Late Cretaceous compression, Eocene compression, a drastic change at around $30 \mathrm{Ma}$ with the collision of Africa and Eurasia and the first rifting in the Gulf of Aden, coeval with the surge of volcanism of the Afar plume (Jolivet and Faccenna, 2000; Faccenna et al., 2013; Jolivet et al., 2016). These coeval events cannot be just coincidences because the Mediterranean region has been a semi-closed system since approximately $35 \mathrm{Ma}$ where internal displacements proceed much faster than the relative motion of Africa and Eurasia at the external boundaries of the system. We now explore these successive periods on various scales, focusing on the Western Mediterranean and the Pyrénées in order to identify the main driving factors of observed deformations, near-field versus far-field.

\section{Different scales}

We first present a brief review of the main parameters that may play a role in the observed deformation, depending upon scale.

\subsection{The scale of the Pyrénées}

\subsubsection{Kinematic boundary conditions, shortening finite rates and pre-orogenic template}

At the scale of the Pyrénées several factors are possibly at play. The first one is the kinematic boundary conditions, whether the Iberian and European plates diverge or converge. A recent reevaluation of the kinematics based on Atlantic magnetic anomalies gives a reliable framework (Macchiavelli et al., 2018) but the precision available on the velocity and direction of relative motion remains debated because of the magnetic quiescence during the Cretaceous Normal Superchron (Aptian to Santonian) and because of uncertainties on the interpretation of the nature of the $\mathrm{J}$ oceanic magnetic anomaly in the southern North Atlantic that makes it a doubtful isochron (Nirrengarten et al., 2018). This is mostly true for the rifting period also because the width of the deforming zone is poorly known. A series of rifts have been described from the center of Iberia to the North Pyrenean Zone, but the kinematics and amount of extension accommodated by each of them is poorly constrained (Canérot, 2016; Rat et al., 2019). These Mesozoic rifts had already accommodated significant extension earlier, during the Permian and Triassic (Saspiturry et al., 2019), a fact that is often overlooked, which leads to the overestimation of the relative motion between Iberia and Europe during the Mesozoic rifting. Angrand et al. (2020) instead propose reconstructions where the Iberia-Europe plate 


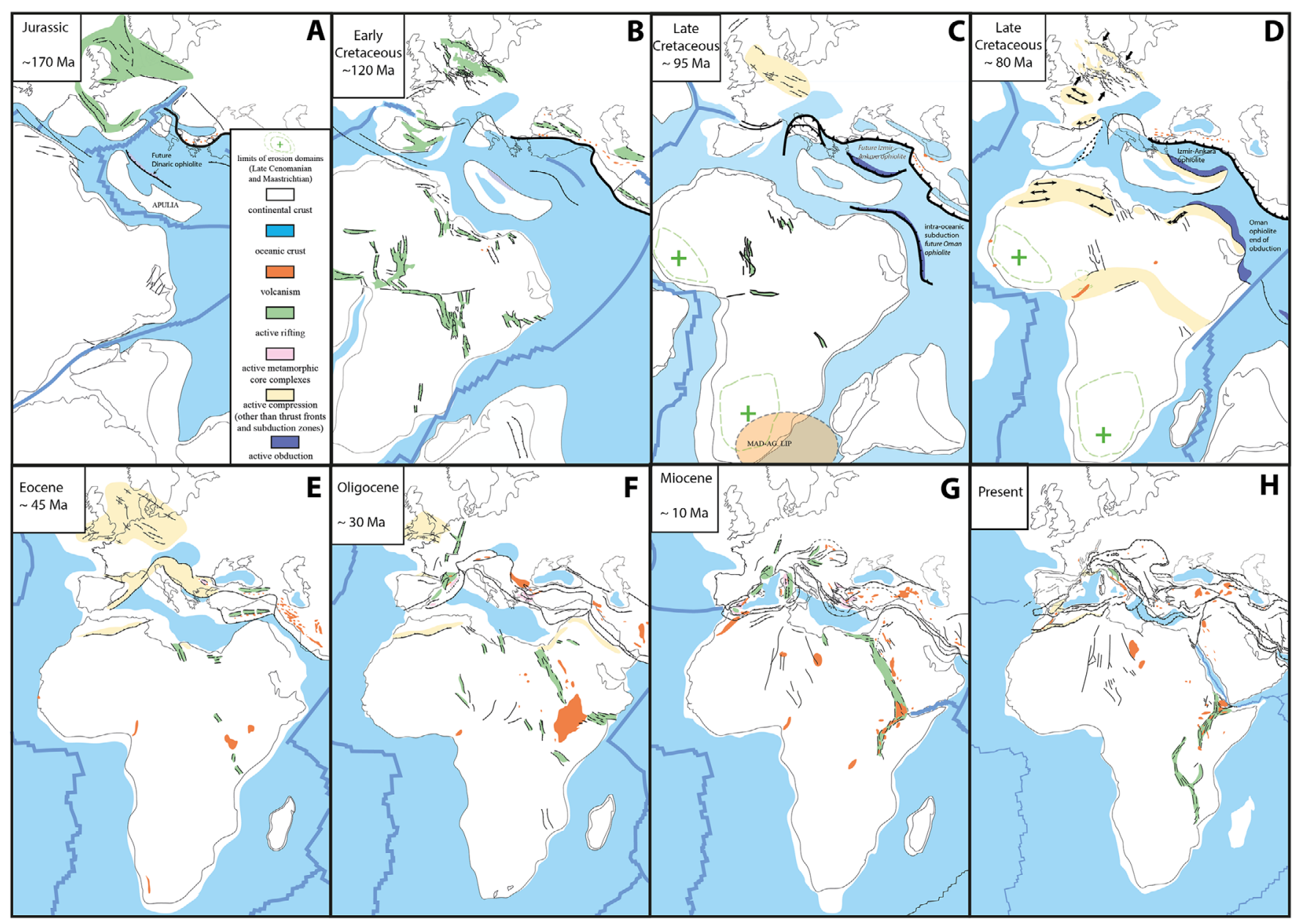

Fig. 9. Reconstructions of the Tethys Ocean from the early Cretaceous to the Present and the evolution of the Mediterranean region in this largescale framework. This figure is adapted from Jolivet et al. (2016a) with the addition of the evolution of northern Europe and the North Sea (Evans et al., 2003).

boundary is a wide deformation zone that does not need a localized left-lateral motion on the Pyrénées, at variance with several available models (Choukroune and Mattauer, 1978; Olivet, 1996; Sibuet et al., 2004; Handy et al., 2010; Jammes et al., 2010; Vissers and Meijer, 2012; Barnett-Moore et al., 2016). Then, the continuation of the rift zone toward the east (toward the Alps) is not precisely known, but Tavani et al. (2018), based on a detailed study of the Marguareis extensional domain in the southern Briançonnais and a compilation of observations in the transition zone between the Pyrénées and the Alps, recently concluded that rift basins similar to the North Pyrenean basins, with similar stratigraphy and timing, can be recognized until the South Provence Basin, the Vocontian Basin and the Marguareis basin, with NE-SW transfer faults. During the compressional period, the amount of shortening is more precisely estimated thanks to crustal-scale sections across the Pyrénées (Vergés et al., 2002; Mouthereau et al., 2014; Grool et al., 2018; Teixell et al., 2018; Espurt et al., 2019) but they also come with significant uncertainties and differences. Further south, the exact timing and amount of shortening on the southern boundary of Iberia (Betics) remains to be precisely constrained in the Late Cretaceous (Daudet et al., 2020).
Balancing crustal-scale sections across the Pyrénées is indeed a delicate exercise because the pre-orogenic geometry and the amount of finite shortening are not consensual. Despite the wealth of vintage and more recent seismic data with up-todate techniques across the belt, some first order features are debated, as illustrated by the recent syntheses of Teixell et al. (2018) and Chevrot et al. (2018). The geometry of subcontinental mantle at shallow depth below the Mauléon Basin is not similar in all published works, which has drastic consequences when estimating the amount of finite shortening. On the single ECORS profile in the Central Pyrénées or along cross-sections nearby, published amounts of shortening vary between $\sim 90 \mathrm{~km}$ and more than $160 \mathrm{~km}$ (Muñoz, 1992; Roure et al., 1996; Beaumont et al., 2000; Muñoz et al., 2013; Mouthereau et al., 2014; Grool et al., 2018; Muñoz et al., 2018; Teixell et al., 2018). Then, the amount of apparent shortening in the sedimentary cover of the North Pyrenean Zone or Nappe des Marbres in the Basque-Cantabrian basin taken up by pre-orogenic salt-tectonics is much larger than usually considered. The recent works of Ducoux et al. (2019) in the Nappe des Marbres, Menant et al. (2016) and IzquierdoLlavall et al. (2020) or Labaume and Teixell (2020) on different sections of the Chainons Béarnais, or Ford and Vergés 


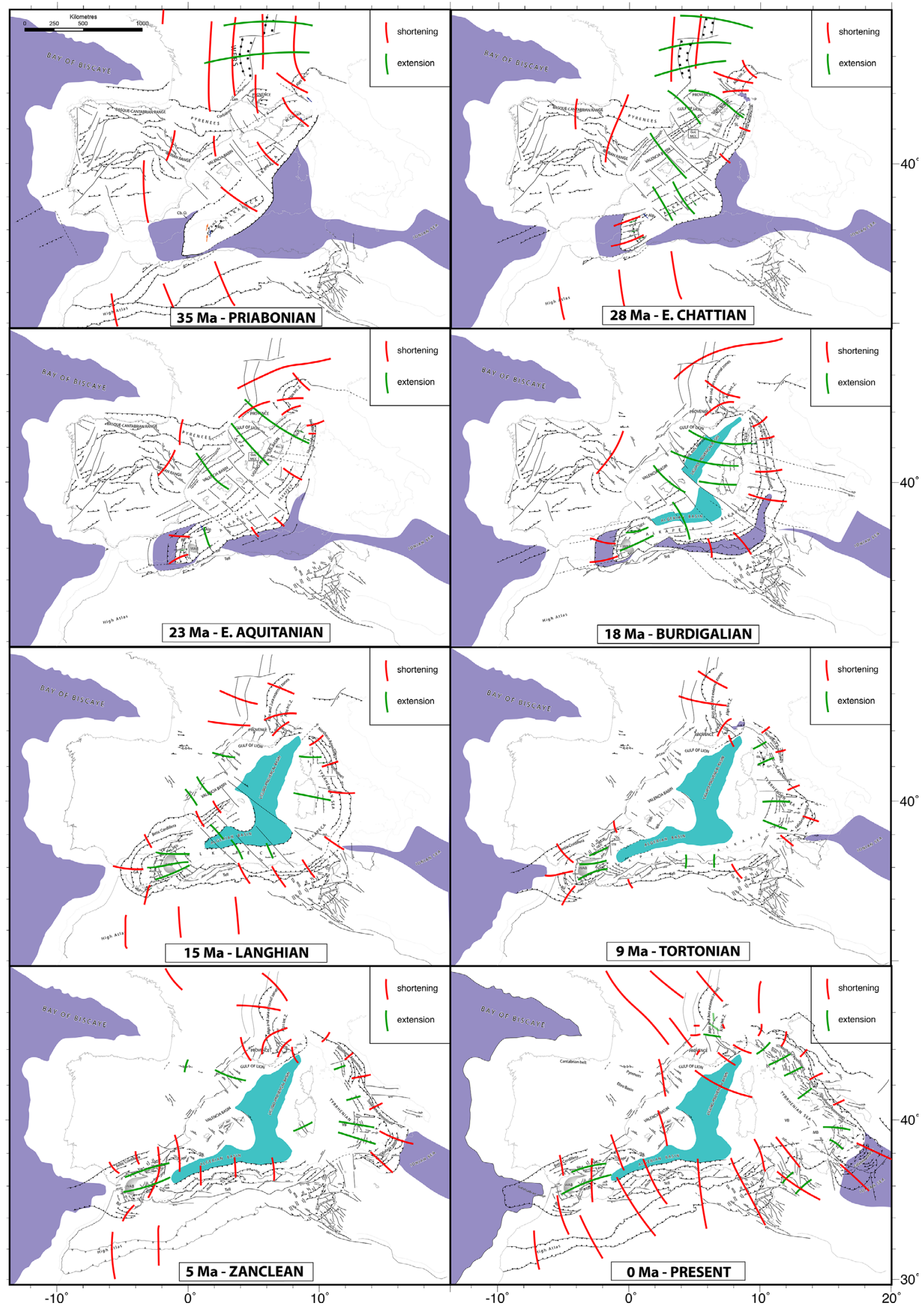

Fig. 10. Schematic evolution of the shortening and extension directions through the reconstructions of Romagny et al. (2020) after Bergerat (1987), Séranne (1999), Ziegler and Dèzes (2007), Dèzes et al. (2004), Frizon de Lamotte et al. (2000, 2008), Walpersdorf et al. (2018), Cornet and Burlet (1992) and Baize et al. (2013). 
(2020) in the eastern Pyrénées show that a significant part of the apparent shortening shown by the deformation of the Mesozoic cover is in fact due to early salt-tectonics during the rifting episode and partly before the onset of the HT-LP Pyrenean metamorphism. Wicker and Ford (2021) also show that early salt tectonics can be recognized also in the southern part of the Provence fold and thrust belt and that the famous Beausset klippe (Bertrand, 1887) could be interpreted as a megaflap of the Bandol diapir. This must significantly reduce the overall finite shortening across the belt calculated on balanced cross-sections and the kinematic consequences have not yet been fully evaluated. Ford and Vergès (2020) show in addition that a significant component of sinistral strike-slip tectonics should be considered during rifting.

The width of the Pyrenean rift is similarly variable and the least known figure is the width of the exhumed mantle domain during rifting that varies from $15 \mathrm{~km}$ (Jammes et al., 2010a, Jammes et al., 2010b; Lagabrielle et al., 2010) to $50 \mathrm{~km}$ (Mouthereau et al., 2014), not mentioning the $300 \mathrm{~km}$ of a true oceanic domain proposed by Vissers and Meijer (2012). The timing of the first shortening of paleo-margins is also variable in the literature, from $50 \mathrm{Ma}$ to $83 \mathrm{Ma}$ (Mouthereau et al., 2014; Teixell et al., 2018), and evidence for the initiation of flexural basins in the northern and southern forelands all point to the Campanian, thus around $83 \mathrm{Ma}$ or even earlier as soon as the Coniacian and Santonian (Bilotte, 1985; Grool et al., 2018; Andrieux et al., 2021). The first contact between the two necking zones during shortening dates back to the Campanian (Mouthereau et al., 2014). Issautier et al. (2018) rather consider that these early deformations correspond to buckling of the European lithosphere under the compressional regime imposed by the Africa-Eurasia convergence. Finally, the significance of the flat and shallow Moho below the eastern Pyrénées is also discussed, whether it results from the shortening of a different pre-orogenic geometry compared to the western Pyrénées (Chevrot et al., 2018) or to the result of post-orogenic extension during the rifting of the Gulf of Lion (Wehr et al., 2018; Jolivet et al., 2020).

All these first order uncertainties make the relations between the Africa-Eurasia convergence through time, which is more precisely constrained, and the tectonic evolution of the Pyrénées, difficult to assess. It is particularly difficult to be conclusive on the amount of shortening in the Eastern Pyrénées where the influence of post-orogenic thinning during the rifting of the Gulf of Lion is major. If we consider the $125 \mathrm{~km}$ estimated by Vergès et al. (2002), it is not much different from the average values proposed for the Central Pyrénées. East of the Catalan transfer zone, below the present-day Gulf of Lion passive margin, the amount of pre-Oligocene shortening is unknown. A gradient of shortening from the Cantabrian Range and Western Pyrénées $(\sim 90-100 \mathrm{~km})$ to the Central Pyrénées $(\sim 120 \mathrm{~km})$ seems instead more consensual (Teixell et al., 2018) and in agreement with prediction of large scale kinematic models (Macchiavelli et al., 2018). Note, however, that the kinematic model of Macchiavelli et al. (2018) does not include any intraplate shortening within Iberia. It is also logical given the transition from the Bay of Biscay to the orogen, but these figures should be revised once the effect of early salt tectonics is subtracted. Moreover, the width of the early
Cretaceous rifts is unknown and restoring the section at crustal scale is thus difficult.

One major parameter at this scale is the east-west variation of the pre- to post-orogenic structural template. Given the uncertainties on the amount of shortening briefly discussed above, reconstructing the pre-orogenic geometry of the margins is not well constrained. Tugend et al. (2014) tried to circumvent this difficulty by mapping the rift domains within the Pyrénées and compare with the nearby margins of the Bay of Biscay. They come up with a rift with constant width across the entire belt, closing westward below the Cantabrian Range and relayed northward by the Bay of Biscay rift closing eastward. Lescoutre and Manatschal (2020) further show how the geometry and interactions in space of these two rift systems can explain the present-day geometry of the Western Pyrénées and the transition with the Cantabrian Range. Cadenas et al. (2021, in prep.) and Miro (2020) further show that the rifting should be divided in two main stages after the first Triassic episode: a first Late Jurassic to Barremian stage, mainly distributed south of the present-day Pyrénées and a second Aptian-Cenomanian stage more focused in the Pyrénées.

An alternative approach is to consider the distribution of the Internal Metamorphic Zone (IMZ) high-temperature metamorphism. Earlier papers described a gradient of temperature from west to east in the North Pyrenean rifts where the mantle is exhumed (Clerc and Lagabrielle, 2014; Clerc et al., 2015b), but more recent studies show a more complex situation. The westward decrease of the maximum recorded temperature is clear from the Boucheville Basin to the Chainons Béarnais, but maximum temperatures as high as those of the Boucheville Basin are also recorded in the Nappe des Marbres near the western end of the belt, south of the Cinco Villas Massif(Ducoux et al., 2019; Ducoux et al., 2021a). How does this distribution of maximum temperatures exactly fit the reconstruction of the early Cretaceous rift is not precisely known, but the asymmetry of the thermal structure suggests that the rift was also asymmetric, an observation compatible with current models of mantle exhumation below low-angle detachments (Lagabrielle et al., 2019a, 2019b; Lescoutre et al., 2019; Ducoux et al., 2019, 2021a; Lescoutre and Manatschal, 2020, Saspiturry et al., 2020). The triangular shape of the Bay of Biscay oceanic domain has suggested that the amount of extension was larger in the west than in the east, but this gradient is not clear either, and the lack of syn-rift kinematic indicators in the field does not help. The direction of extension during rifting is often deduced from that of supposed transfer faults such as the Pamplona Fault, which existence and significance is debated (Tugend et al., 2014; Saspiturry et al., 2019; Lescoutre and Manatschal, 2020). The NNE-SSW direction of extension can also be deduced from the geometry of the Arzacq basin (Masini et al., 2014; Saspiturry et al., 2019; Issautier et al., 2020; Ducoux et al., 2021b). Frasca et al. (2017), however, suggest a significant component of sinistral strike-slip tectonics during the formation of rift basins from the Early Cretaceous to the early Late Cretaceous, based on an analysis of Mesozoic supra-salt syn-tectonic sedimentation in the eastern Pyrénées. The strike-slip component is suggested by the arrangement of salt walls in map view related to basement faults. 


\subsubsection{Crustal root and body forces, rheological issues}

Crustal thickening during the Eocene has increased the potential gravitational energy stored in the Pyrenean crust, partly balanced by the lithospheric root. If no oceanic slab is visible in tomographic models underneath the Pyrénées, a crustal root is nevertheless present (Chevrot et al., 2014; 2018) that applies a load on the crust and prevents the formation of a higher relief. Below the eastern Pyrénées, this root is not present and several possibilities have been discussed, either a different amount of finite shortening, different distribution of strain and a different pre-orogenic template or a removal of the root during the rifting of the Gulf of Lion (Chevrot et al., 2018; Jolivet et al., 2020).

These different boundary and body forces apply on a lithosphere with a given rheology and a given pre-orogenic tectonic history and inheritance is thus important to consider, especially in the early history of mountain belts (Manatschal et al., 2021). The nature of the deep crust during the formation of the orogen is thus an important question to address. Whether weak or strong, it will react differently. The continental basement of the Iberian and European lithospheres has been strongly mobilized during the Variscan orogeny until the exhumation of granulitic domes during late-orogenic extension (Cochelin et al., 2017; Saspiturry et al., 2019). Granulitic slices are observed in the IMZ associated with peridotites. They are granulitic paragneisses, catazonal marbles, intermediate and basic charnockites equilibrated at $8 \mathrm{kbar}$ and $750-800^{\circ} \mathrm{C}$ associated with a Hercynian thermal anomaly around $300 \mathrm{Ma}$ (Vielzeuf and Kornprobst, 1984). The late- to post-orogenic evolution of the Variscan orogen in the Pyrénées was characterized by distributed extension and the exhumation of migmatitic gneiss-cored metamorphic core complexes with intense magmatism (Denèle et al., 2007, 2008, 2009; Cochelin et al., 2017), a situation similar to that of the Aegean region during the Oligocene and Miocene (Jolivet and Brun, 2010). The lithology of the lower crust underneath the Pyrénées and more specifically the ratio between resistant granulites and weaker gneiss and migmatites is unknown. It is, however, likely that the middle crust and part of the lower crust after the end of the collapse of the orogen were highly heterogeneous essentially made of granites and gneiss and the lower crust locally made of granulite and mafic material underplated during the Permian after the end of the Variscan orogeny as suggested by the study of the Sondalo gabbroic complex in the Central Alps (Petri et al., 2017). This suggests a rather weak bulk rheology for the middle crust, opening the possibility of a decoupling during Pyrenean shortening. Bellahsen et al. (2019) and Airaghi et al. (2020) further show that fluid circulation during pre-orogenic rifting episodes since the Permian have significantly modified the mineralogical content of the upper crustal basement, with intense sericitization, and thus weakened the resistance of the upper crust, a possible explanation for the observed distributed deformation during Pyrenean shortening. The early Cretaceous rifting episode was locally associated with mantle exhumation and serpentinisation, but the intensity of this serpentinisation differs between peridotite bodies (Clerc et al., 2014) that were exhumed within the upper crust during rifting. Such weak levels might have nevertheless been used as decoupling levels during convergence (Tugend et al., 2014; Manatschal et al., 2021).
Models of formation of magma-poor passive margins suggest that weakening of the crust and weakening of the upper mantle by serpentinisation during extension can lead to lower crust and mantle exhumation with low-angle extensional shear zones (Lavier et al., 1999, 2019). Although large uncertainties remain on the mechanical stratification of the pre-convergence crust, it was thus probably in average rather weak with several decoupling levels and a weak upper crust. The rapid onset of convergence after the end of the rifting episode in the Santonian (see Mouthereau et al., 2014 for a review) or Eocene (Vacherat et al., 2017) suggests that the lithosphere was still hot and thus weak when compression started. This relative weakness helped the progressive localization of a new plate boundary in the Pyrénées during the Late Cretaceous, as described by Dielforder et al. (2019). From a situation where compressional stresses were recorded across a wide zone from the north of Africa to northern Europe, compressional deformation progressively localized within the former rift systems, i.e. the Pyrénées and the Iberian Chain. The degree of Late Cretaceous strain localization in the future Betic-Rif orogen is unknown, but Daudet et al. (2020) show that a foreland basin was already present there in that period and subsided further around $50 \mathrm{Ma}$.

The formation of a crustal root by underthrusting of the Iberian crust underneath the Pyrénées as well as the presence of mantle rocks high up in the nappe stack introduce sharp lateral density gradients and thus a complex distribution of body forces. Souriau et al. (2014) show that the extensional earthquakes within the Central Pyrénées are intimately associated with contacts between blocks of different densities and that it might not necessarily reflect the regional stress regime. Depending upon the completeness of metamorphic recrystallization in the subducted portion of Iberian crust and the intensity of serpentinisation in mantle bodies incorporated in the orogenic wedge, the distribution of densities can significantly vary, even more so considering the along-strike changes in the overall structure of the orogenic wedge shown by receiver-function profiles (Chevrot et al., 2018). Using homogeneous layers and the 3-D modelling software GeoModeller, Wehr et al. (2018), however, successfully reproduce the distribution of gravity anomalies over the Pyrénées. This may suggest either that the subducted Iberian crust has not been eclogitized nor otherwise intensely metamorphosed during underthrusting, or that the depth of interfaces should be modified for the deep parts of the wedge where the deep root is present. Wehr et al. (2018) furthermore show that a strong lowdensity anomaly is required in the upper mantle and/or lower crust to account for the negative Bouguer anomaly below the eastern Pyrénées. They conclude that a high-density lower crust is missing below this region. Dufréchou et al. (2018) also conclude to the absence of high-density lower crust below the eastern Pyrénées, except locally where the lower crust could have been eclogitized. As discussed later, rifting of the Gulf of Lion might be responsible for the removal of the lower and associated upper mantle from below the eastern part of the belt, which could also explain the fast cooling and exhumation period around $30 \mathrm{Ma}$ documented by low-temperature thermochronology (Jolivet et al., 2020). One point of discussion is the extent of this lower crust removal process during the OligoMiocene rifting, how far did it reach westward underneath the Pyrénées. The interpretation of Jolivet et al. (2020) is that the 
westernmost affected region is the region under which the crustal root disappears on the seismic profiles, between profiles $\mathrm{C}$ and D (Fig. 11)

\subsection{The scale of the Western Mediterranean}

3.2.1 Tectonic drivers at the scale of the Western Mediterranean, convergence vs slab retreat, asthenosphere vs lithosphere

Before the major change of subduction dynamics at 35-30 Ma, the relative motion of Africa and Eurasia was first divergent before 90-84 Ma and convergent afterward in the Western Mediterranean realm (Fig. 6). After $32 \mathrm{Ma}$, while the northward motion of Africa toward Eurasia continued at the same pace or even slower, the retreat of the slab subducting below Sardinia and Corsica became the dominant kinematic feature. All reconstructions (Gueguen et al., 1998; Rosenbaum et al., 2002a; Jolivet et al., 2003; Lacombe and Jolivet, 2005; Romagny et al., 2020; Mantovani et al., 2020) show arcs moving outward at high velocities (from 3 to more than $10 \mathrm{~cm} / \mathrm{yr}$ ), outpacing the overall convergence (Figs. 6, 10 and 13). Motion paths on Figures 13 and 14 show that the fast displacements of arcs during slab retreat are dominant over the velocity of Africa-Eurasia convergence and the absolute motion of the two plates.

After $32 \mathrm{Ma}$, most of the deformation in the Western Mediterranean was then no longer under the control of convergence but of slab retreat and associated asthenospheric flow. The thick crust of mountain belts (Provence, Alpine Corsica, Internal Apennines, Calabria) formed during earlier stages was then thinned in the back-arc domain, while new ones formed in the vicinity of the retreating subduction zones and were progressively dilacerated during the migration of the thrust front (Jolivet et al., 1998; Jolivet and Faccenna, 2000; Faccenna et al., 2001a; Rosenbaum et al., 2002a; Jolivet et al., 2003; Lacombe and Jolivet, 2005; van Hinsbergen et al., 2014; Romagny et al., 2020).

One of the main questions is the transition in space from the Pyrénées to the extending domain in the east (Gulf of Lion) and from the Alps to the Apennines which migrated in opposite directions after 35-30 Ma (Fig. 10). Similarly, at around $16 \mathrm{Ma}$, the slab retreating southward carried the AlKaPeca blocks in contact with the North African margin, and a new major slab tearing event divided it in two parts, each retreating in opposite directions, westward and eastward, forming the opposite Calabrian and Gibraltar subduction zones. The width of the slab portions were progressively reduced and the velocity of retreat accordingly increased, outpacing even more the convergence (Wortel and Spakman, 1992; van der Meulen et al., 1998; Faccenna et al., 2005; Govers and Wortel, 2005; Jolivet et al., 2021) and a large component of strike-slip motion is recorded along the northern and southern margins of the Alboran domain and north of Sicily (Fig. 13).

The case of the Pyrénées is, however, peculiar. While the Eastern Pyrénées where actively dismantled by the underlying asthenospheric flow related to slab retreat (Jolivet et al., 2020) or other asthenosphere dynamics (Gunnell et al., 2009; Huyghe et al., 2020; Calvet et al., 2021), the Central and Western Pyrénées were still recording shortening until the Late Oligocene or the base of the Miocene (21 Ma) (Jolivet et al.,
2007; Mouthereau et al., 2014; Labaume et al., 2016; Muñoz et al., 2018). This shows that the extensional stress regime imposed by the retreat of the Apennines slab did not affect the whole of the Pyrenean orogen and that compressional stresses were still transmitted through the lithospheric stress-guide across the Africa-Iberia-Europe plate boundary zone.

After the end of this episode of back-arc extension, N-S compression resumed in the Betics around $8 \mathrm{Ma}$ and finally most of the Western Mediterranean was under N-S compression and locally E-W extension (Meghraoui et al., 1986; Yelles et al., 2009; Strzerzynski et al., 2010; Billi et al., 2011; Meghraoui and Pondrelli, 2012; Medaouri et al., 2014; Soumaya et al., 2018; Zitellini et al., 2019; Strzerzynski et al., 2021) as shown by the current seismic activity (Figs. 3 and 4). The Africa-Eurasia convergence is certainly one of the main drivers in this new situation, leading to the localization of shortening along the northern margin of Africa and reactivation of the former passive and strike-slip margins of the Alboran domain, coeval with a second episode of shortening all along the High Atlas mountain range (Frizon de Lamotte et al., 2000; Jolivet et al., 2006; Frizon de Lamotte et al., 2008; Lanari et al., 2020a, Lanari et al., 2020b). The northward asthenospheric flow due to large-scale convection is also an important driver of crustal deformation, especially around the slab dipping vertically under the western Betics and the Alboran Sea as recently suggested by Spakman et al. (2018) and Capella et al. (2019).

\subsubsection{The scale of the Eurasia-Africa plate boundary}

At the scale of plates (Fig. 9), the relative motion of Africa and Eurasia is an important driver of crustal deformation. Whether the relative motion is divergent (before $84 \mathrm{Ma}$ ) or convergent (after $84 \mathrm{Ma}$ ), extensional or compressional stresses will be transmitted through the lithospheric stressguide. Plates are, on the other hand, carried by the convecting mantle underneath. In the Late Cretaceous, compression is recorded across a very large domain from the center of the African plate to Northern Europe, this period culminating with the obduction of ophiolites in the eastern Mediterranean and Middle East. The transmission of stresses through the lithosphere can be modulated by the pattern of convection underneath, whole-mantle convection or local convection due to slab retreat in the Mediterranean (Jolivet et al., 2016a). Plate motion and deformation being driven by slab pull and/or basal drag by the convecting mantle underneath (see Fig. 1 and related text), any change in the deep convection pattern will reflect in the relative and absolute motions of plates. All along the former Tethyan Ocean, from Indonesia and the Himalayas, all the way to the Western Mediterranean, India, Arabia and Africa are carried by the asthenospheric conveyor belt toward the north faster than the slow motion of the Eurasian plate, leading to convergence (Becker and Faccenna, 2011; Faccenna et al., 2013b). This convergence decreases from east to west from more than $5 \mathrm{~cm} / \mathrm{yr}$ to less than $1 \mathrm{~cm} / \mathrm{yr}$ (Fig. 6). One important aspect at this scale is the change in the direction of convergence during the Cretaceous, from a large component of strike-slip motion toward pure convergence, perpendicular to the Africa-Eurasia plate boundary zone (Fig. 6) and the associated changes in the convection pattern. 

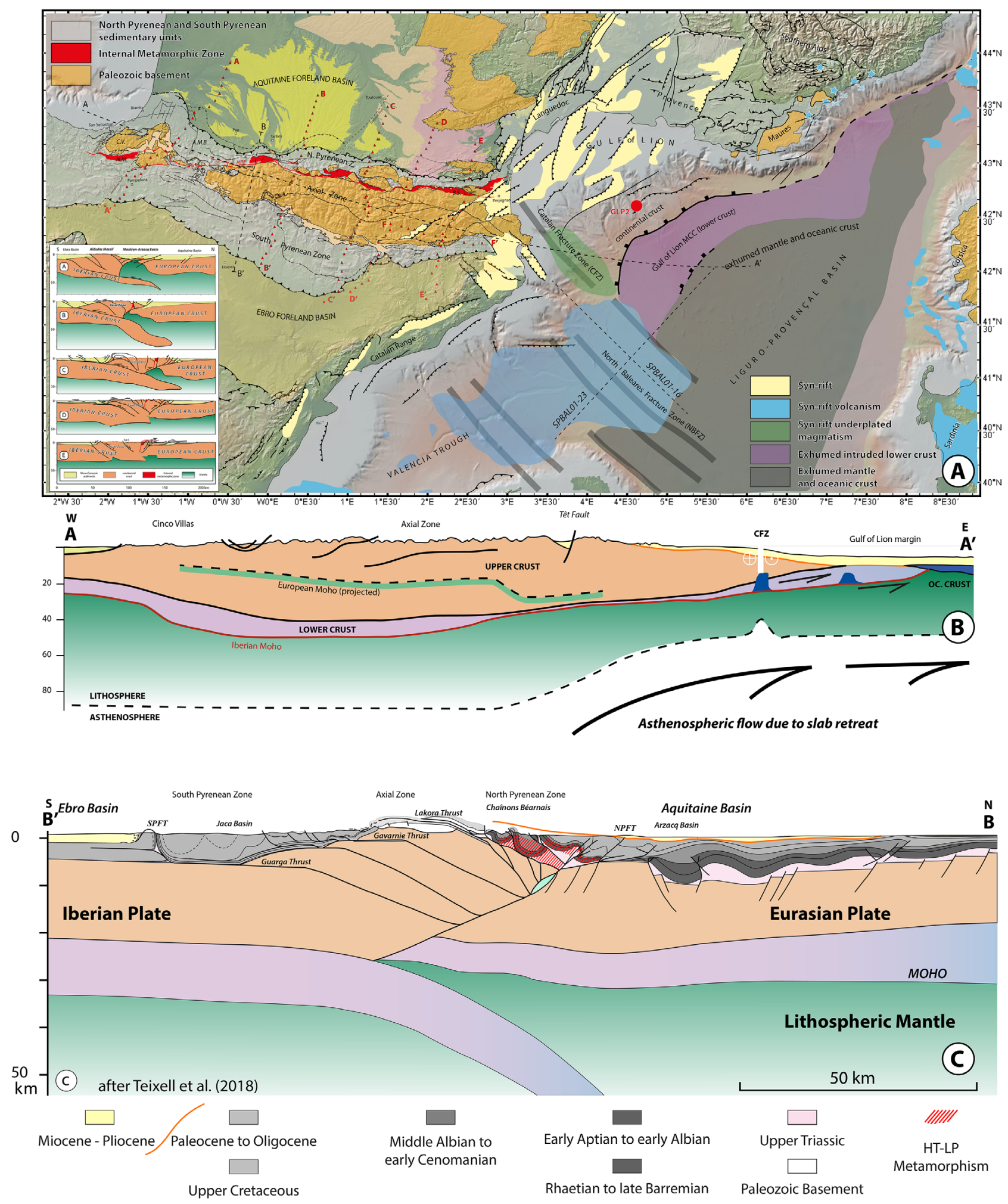

Mediterranean Tethyan III

Tethyan II

Tethyan I

Fig. 11. A. Tectonic map of the Pyrénées, Gulf of Lion and northeastern Valencia Basin. Aligned red triangles show the receiver-functions profiles of Chevrot et al. (2018) interpreted in the inset (from A to E, eastward). Dashed lines offshore show the position of the seismic lines of Figure 17. The dashed line along the strike of the Pyrénées reaching the Gulf of Lion margin is the section shown below. AMB: Arzacq-Mauléon Basin; BS: Boucheville Syncline; CV: Cinco Villas Massif; NMU: Nappe des Marbres Unit; GLP2: Golfe du Lion profond drillhole \#2. B. Along-strike section of the Pyrénées and Gulf of Lion margin. CFZ: Catalan Fracture (Transfer) Zone. C. Across-strike section of the Central Pyrénées, modified after Teixell et al. (2018) showing the different stages discussed in the paper. 


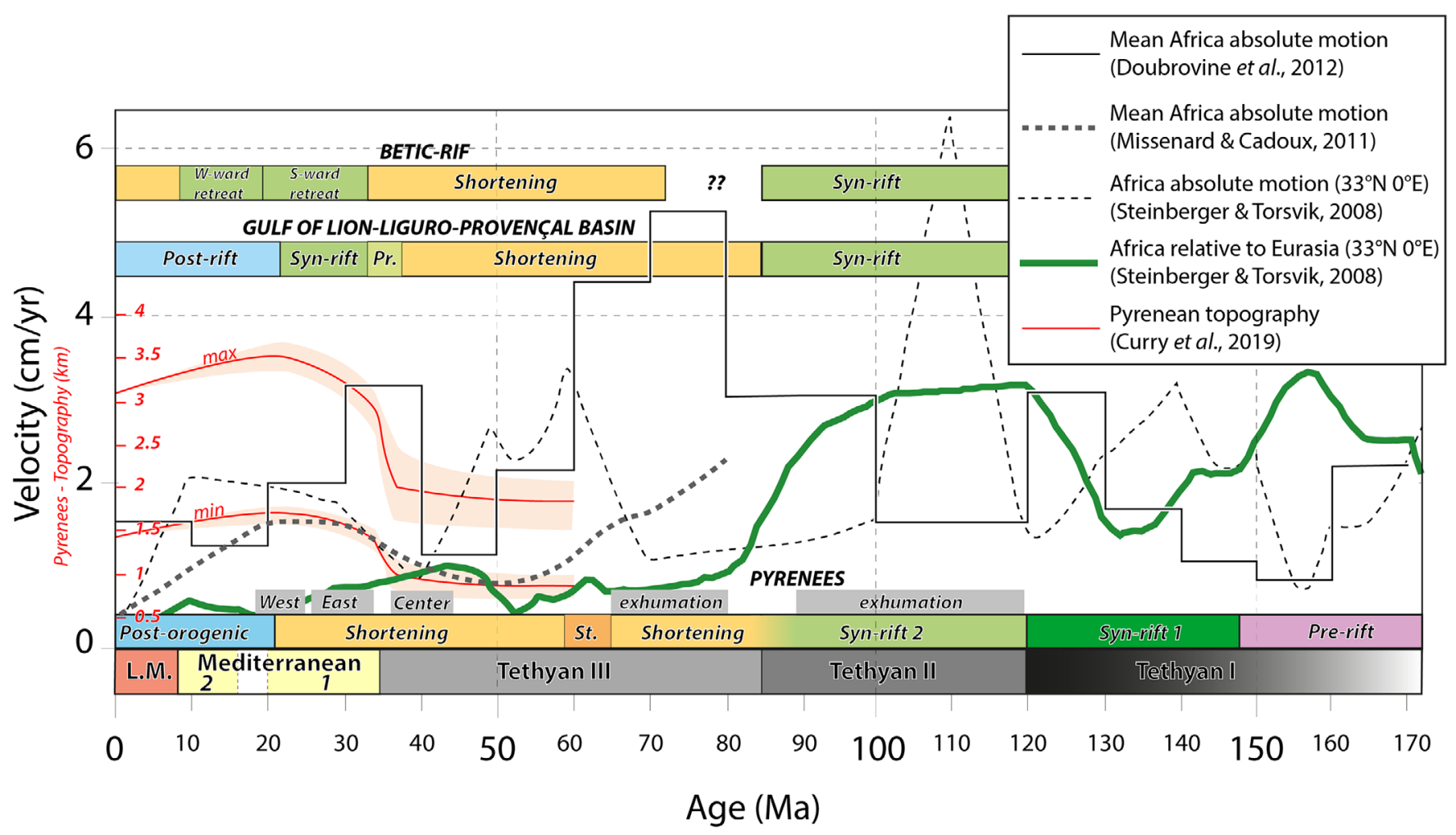

Fig. 12. Timing of various kinematic events in and around the Western Mediterranean region compared to the Pyrénées and the three main periods distinguished in this paper, Tethyan Tectonics, Mediterranean Tectonics and Late-Mediterranean Tectonics (L.M.). Mean Africa absolute motion after Doubrovine et al. (2012) and after Missenard and Cadoux (2012), Africa absolute motion for a point located at $33^{\circ} \mathrm{N}$ and $0^{\circ} \mathrm{E}$ after Steinberger and Torsvik (2008), motion of Africa relative to Eurasia for the same point after Steinberger and Torsvik (2008), topographic evolution of the Pyrénées after Curry et al. (2019).

In the following we discuss these interactions between near-field and far-field stresses for each of the main periods of the geodynamic evolution of the Africa-Eurasia plate boundary, from the early Cretaceous to the Present. We have grouped the different events discussed above and below into three first-order periods (Figs. 11 and 12); (i) Tethyan Tectonics: from early Cretaceous to Eocene, which corresponds to the pre-Mediterranean stage, before the inception of fast slab retreat, this stage is further divided in Tethyan I, II and III to depict the progressive rifting and subsequent shortening episodes (ii) Mediterranean Tectonics: from 35-30 to $8 \mathrm{Ma}$, which is the stage where slab retreat and back-arc extension are mostly active, the typical Mediterranean dynamics and (iii) Late-Mediterranean Tectonics: from $8 \mathrm{Ma}$ to the Present, corresponding to the progressive return to a pre-Mediterranean situation where compressional stresses are not diverted by slab retreat and are again transmitted from Africa to Eurasia.

\section{Tethyan Tectonics, from Early Cretaceous to Eocene}

Before the beginning of slab retreat around $32 \mathrm{Ma}$, the main geodynamic process at work was the relative motion of Africa and Eurasia, divergent before $84 \mathrm{Ma}$, convergent afterward. The Pyrénées started to form at about $84 \mathrm{Ma}$ and the climax of crustal thickening in the Pyrénées across the range is recorded in the Eocene (Bosch et al., 2016; Mouthereau et al., 2014; Teixell et al., 2018; Waldner et al., 2019). The transition from extension to shortening is abrupt in the Pyrénées and is characterized by a change in the sedimentation regime within the North Pyrenean Zone and in the northern foreland with the development of the Aquitaine foreland basin and a tilt of the Axial Zone before the Campanian in the Coniacian-Santonian (Bilotte, 1985; Biteau et al., 2006; Ford et al., 2016; Rougier et al., 2016; Grool et al., 2018, Andrieux et al., 2021; Issautier et al., 2018), which is compatible with the change in the trajectory of Africa relative to Eurasia (Fig. 6). If the geometry of the belt and the rheological properties of the lithosphere (elastic thickness) are strongly impacted by the heritage from the pre-orogenic rifting episode (Angrand et al., 2018; Espurt et al., 2019; Manatschal et al., 2021), the overall tectonic evolution is also dependent on far-field stresses and on the progressive localization of a new zone of deformation during the Late Cretaceous (Dielforder et al., 2019).

\subsection{Late Jurassic to Cenomanian rifting}

After the Permo-Triassic rifting, two episodes of rifting are recorded in Iberia and around (Vielzeuf and Kornprobst, 1984; Puigdefabregas and Souquet, 1986; Vergés and Garcia-Senz, 2001; Lagabrielle and Bodinier, 2008; Miró, 2020; Miró et al., 

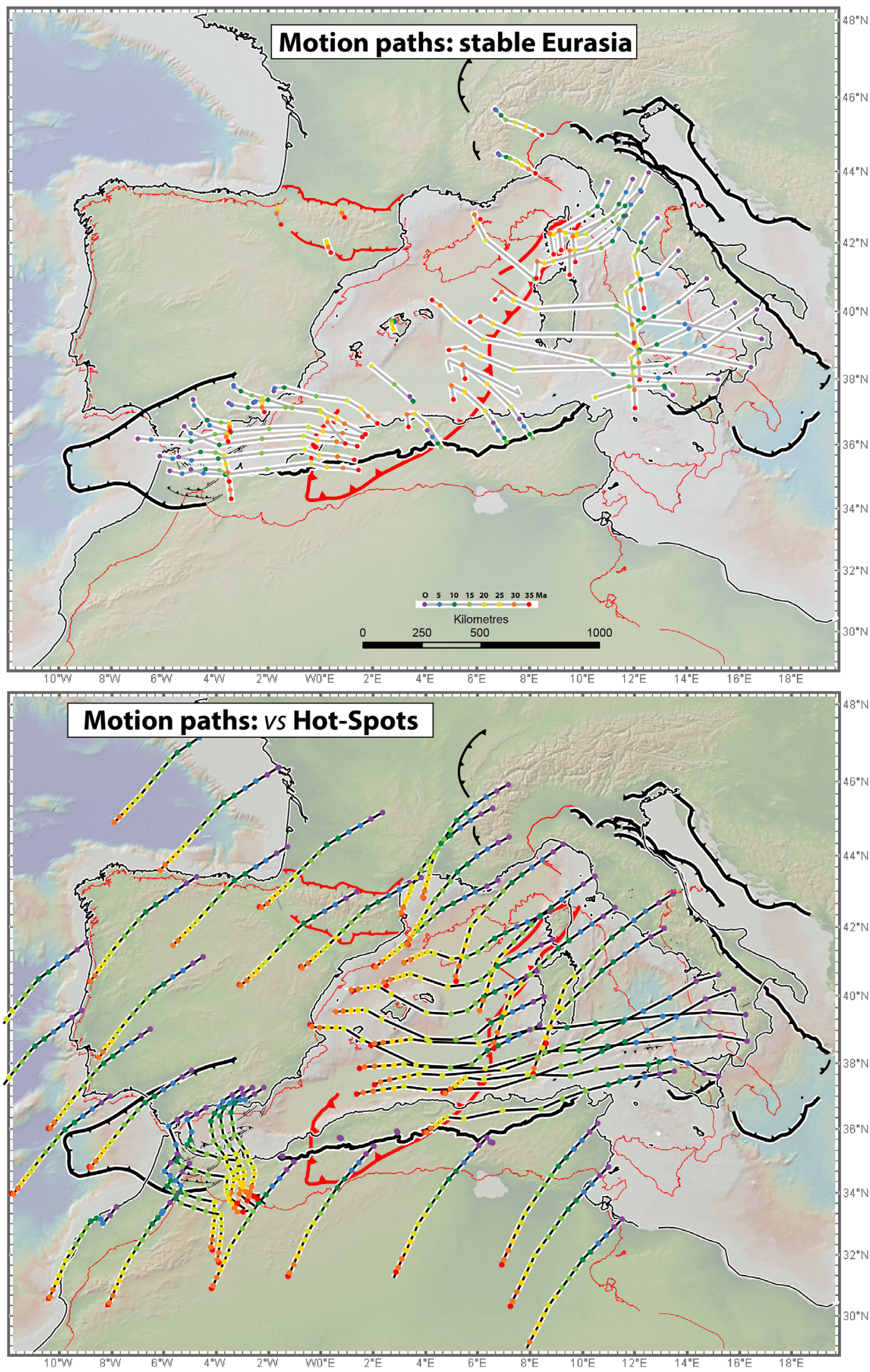

Fig. 13. Motion paths of a series of points within the Western Mediterranean back-arc region calculated from the reconstructions of Romagny et al. (2020). Upper: stable Eurasia; Lower: with respect to hotspots. 


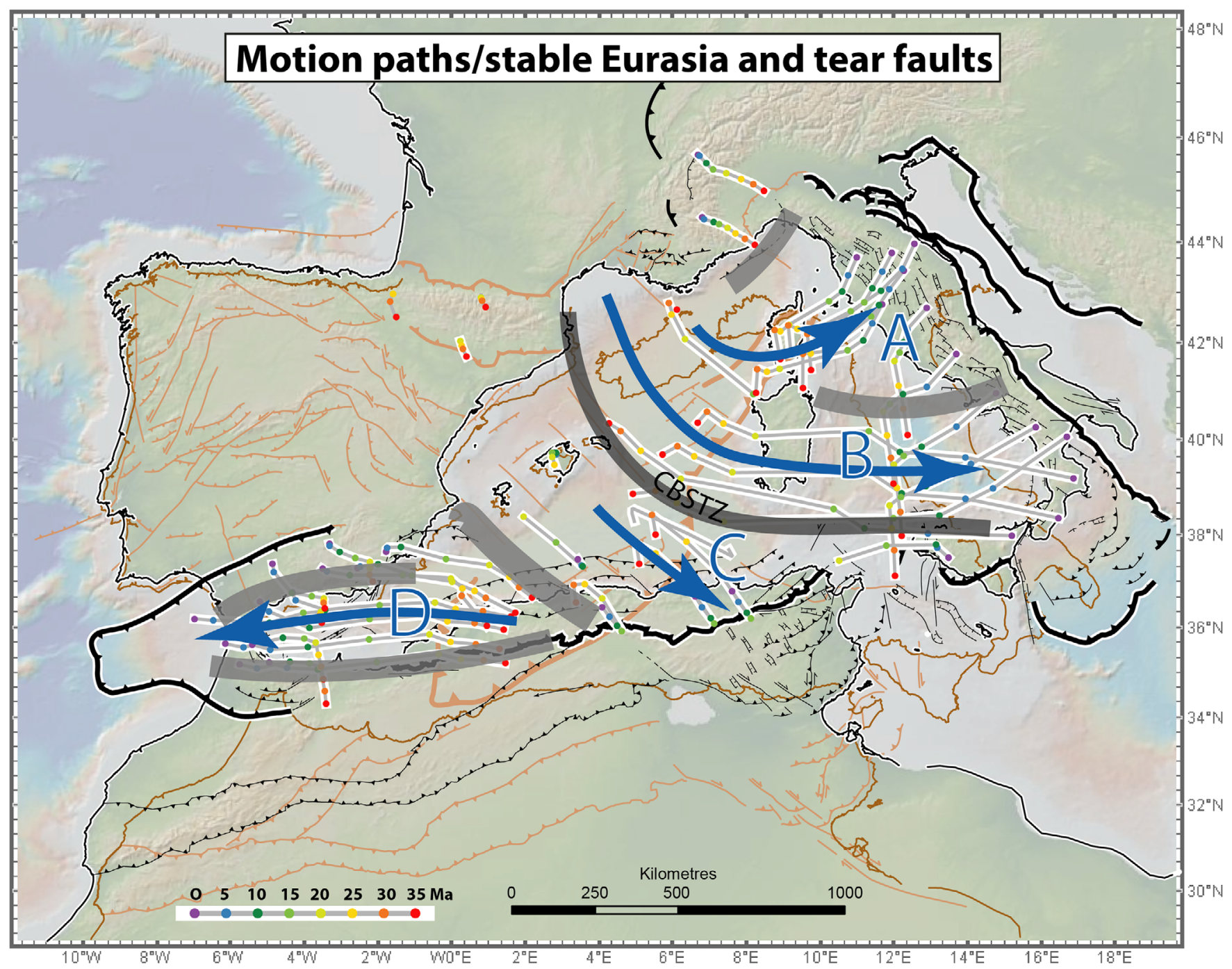

Fig. 14. Motion paths and transfer faults separating coherent domains after the kinematics of Romagny et al. (2020). CBSTZ: Catalan Baleares Sicily Transfer Zone (e.g. Paul Fallot fault of ancient works).

2020). The first episode spans the Late Jurassic and the early Cretaceous (Neocomian) (see Figs. 11 and 12) are recorded within Iberia in the Basque-Cantabrian basin (Miró, 2020; Miró et al., 2020), the Cameros basin and the Maestrat basin (Rat et al., 2019), the Pyrénées (Tavani et al., 2018) and the offshore Columbrets basin (Etheve et al., 2018). At broader scale this rifting stage is also recorded within the westernmost Iberian plate (Alves et al., 2009; Alves and Abreu Cunha, 2009; Soares et al., 2012). The second episode occurs from the Late Aptian to the Cenomanian and is more focused on the Pyrénées (Jammes et al., 2010a, Jammes et al., 2010b; Masini et al., 2014; Tugend et al., 2014). The transition zone toward the Alps shows similar rift basins (Tavani et al., 2018). The Betic Cordillera records continuous rifting spanning the two periods associated with salt tectonics (Pedrera et al., 2020). This distributed rifting and then focalization on the Pyrenean range is actually observed over most of the African continent (Guiraud et al., 2005; Frizon de Lamotte et al., 2015) as well as northern Europe (Ziegler, 1990; Evans et al., 2003; Kley and Voigt, 2008). It corresponds to the opening of the Atlantic ocean and the period of oblique divergence between Africa and Eurasia (Fig. 6). It is also noticeable that the southern active margin of Eurasia above the subduction of the Neo-Tethys is characterized by the formation of back-arc basins at this period (Dercourt et al., 1986; 1993).

\subsection{Late Cretaceous compression and strain localization, lithospheric vs larger-scale}

The first shortening in the Western Mediterranean region is coeval with the first convergence between Africa and Eurasia (Fig. 6). Dielforder et al. (2019) propose that the progressive localization of a new "plate-boundary fault" in the Pyrénées could explain the observed tectonic evolution in the range and the foreland basin, as well as the variable propagation of compressional stresses at long distance in the foreland, until the North Sea (Ziegler, 1988, Ziegler, 1990; Guillocheau et al., 2000; Evans et al., 2003; Dèzes et al., 2004; Ziegler and Dèzes, 2007; Bourgeois et al., 2007; Grool et al., 2018) and Central Europe grabens (Kley and Voigt, 2008). They note that, while 


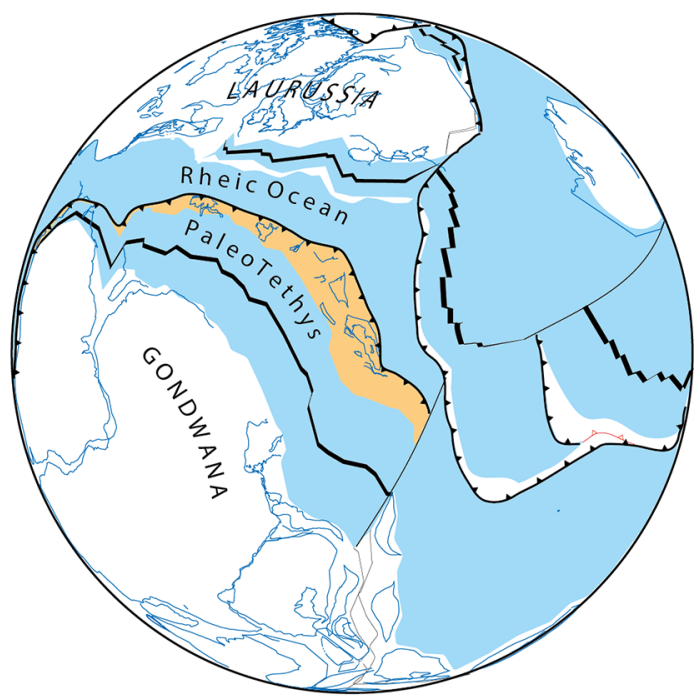

$400 \mathrm{Ma}-$ EMSIAN-EIFELLIAN boundary

(Stampfli \& Borel, 2002)

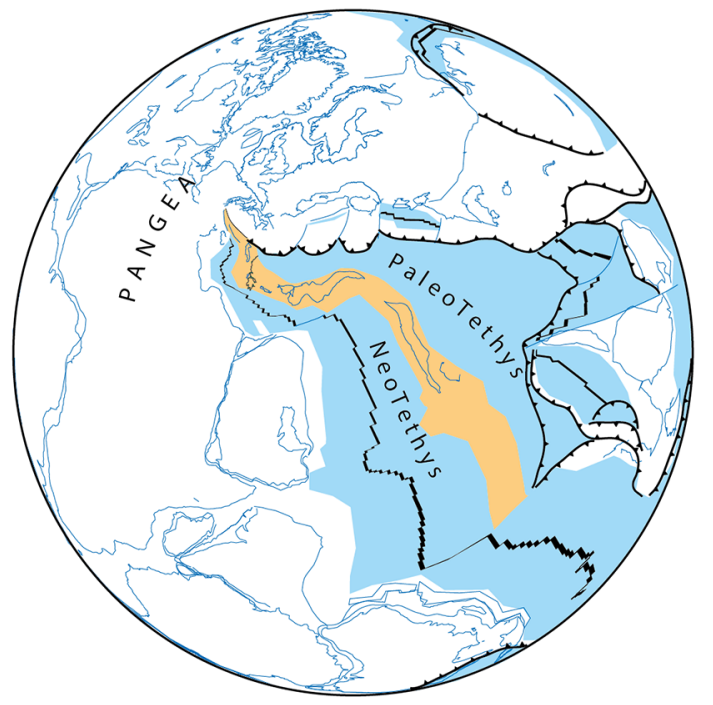

240 Ma- ANISIAN (Stampfli \& Borel, 2002)

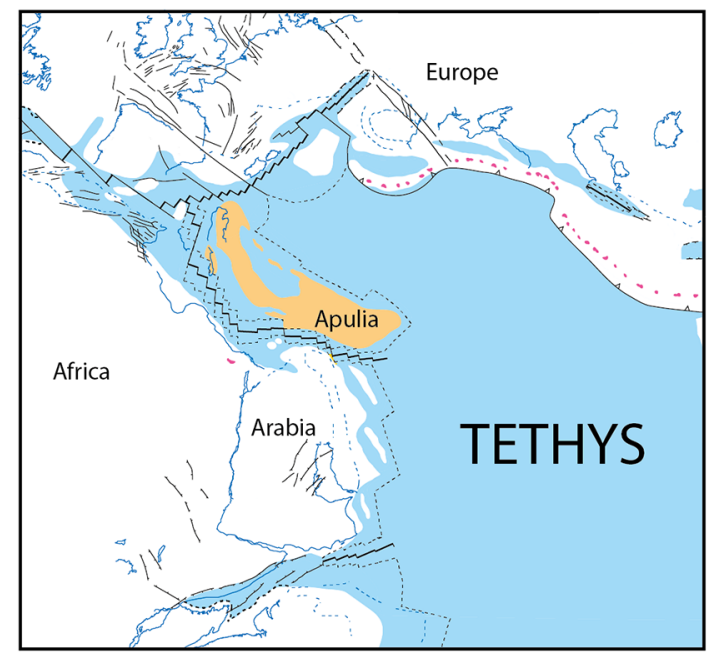

$163 \mathrm{Ma}-$ CALLOVIAN

(Barrier \& Vrielynck, 2008)

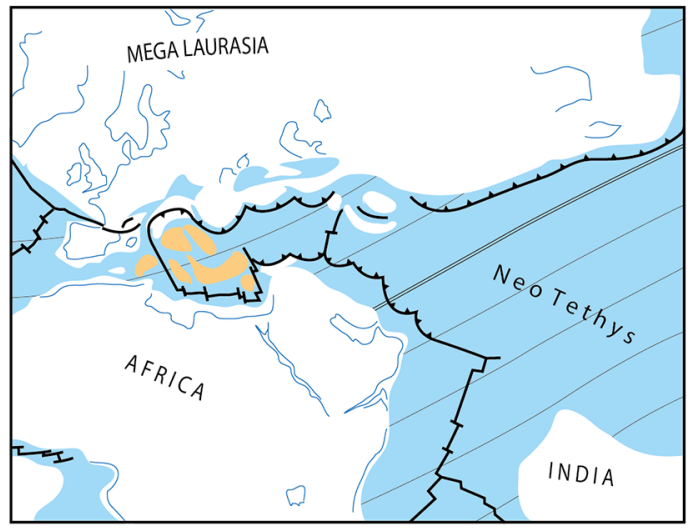

$95 \mathrm{Ma}-$ CENOMANIAN

(Ricou, 1994)

Fig. 15. Four reconstructions of the Tethys Ocean at four stages, Devonian, Anisian, Callovian and Cenomanian after Ricou (1994), Barrier and Vrielynck (2008) and Stampfli and Borel (2002). These reconstructions show the rifting of continental blocks (orange color) away from Gondwana or Africa crossing the ocean to ultimately collide with the southern margin of Eurasia. The most recent of such blocks is the Arabian plate.

rifting was active in the North Sea at the same time as in the Pyrénées, compressional reactivation of the rifted basins is also coeval in the Pyrénées and in the North Sea, until the end of the Cretaceous (Evans et al., 2003).

Except for uplift zones around the British Isles in the Selandian, the Paleocene is a relatively quiet period in the north with little or no-subsidence recorded in the foreland basin around $60 \mathrm{Ma}$ (Sinclair et al., 2005; Mouthereau et al., 2014; Ford et al., 2016), at a time of slow overall convergence (Macchiavelli et al., 2018). Dielforder et al. (2019) propose that the progressive formation of a new fault momentarily caused an increase of compressional stresses that could propagate far in the foreland and then a release once the fault had localized. The origin of compressional stresses is thus to be found in the convergence of Africa and Eurasia in this case, but the variations through time of the stress regime within the foreland is also a consequence of the intrinsic mechanical behavior of the weak European lithosphere.

A look at the larger picture moreover reveals a parallel evolution on a much larger scale (Jolivet et al., 2016a; Mouthereau et al., 2021) (Fig. 9). The Early Cretaceous rifting observed in the Pyrénées, the Bay of Biscay and within Iberia is part of a wide extensional domain that encompasses a large part of Africa and Western Europe, a series of rifts forming at this period within much of the northern half of Africa while the Southern Atlantic Ocean opens. The extended domain includes Iberia and Northern Europe until the North Sea. On the other hand, the Late Cretaceous compression is also recorded on a 
much wider realm, from the inverted rifts in Africa to the North Sea. It starts in Western Europe as soon as the Late Turonian and Coniacian (Ziegler, 1990; Voigt et al., 2006; Lasseur, 2007; Grosheny et al., 2015) thus before the initiation of shortening in the Pyrénées. It leads to the obduction of oceanic lithosphere on the continental margins of Apulia (IzmirAnkara suture zone) and Africa (Oman ophiolite). This period culminates with the so-called Santonian compression that is felt all over Africa (Guiraud et al., 2005). The Eocene is also a period of compression over a wide region from the High Atlas to the Rif-Betic arc, the Pyrénées, the Alps and further north, before the subduction regime changed in the Mediterranean and back-arc basins started to form. The relatively slow AfricaEurasia convergence during the Paleocene (Rosenbaum et al., 2002a, 2002b) (Fig. 12) could also partly explain the low recorded deformation at this period. Moreover, the effect of the establishment of the Icelandic plume around $64 \mathrm{Ma}$ on the stress regime in Western Europe (White and McKenzie, 1989; Nadin et al., 1997; Nielsen et al., 2002) should also be looked at.

\subsection{Plate motion/deformation and convection}

At large scale, the respective roles of the lithosphere as a stress guide and of the convective mantle underneath are still to be explored. The long-term evolution of the Paleo-Tethys and Neo-Tethys shows the repetition of a similar scenario with large continental blocks detaching from the main southern continent and migrating northward across the Tethys to finally collide with Eurasia (Fig. 15) (Jolivet et al., 2016a). This same scenario is repeated from the Devonian to the Present, the most recent of such blocks being Arabia (Jolivet and Faccenna, 2000; Bellahsen et al., 2003; Faccenna et al., 2013b). This behavior, typical of the Tethyan E-W oceanic domain, signs the permanence of a similar engine at the scale of the mantle and it emphasizes the cooperative work of subduction zones (Tethyan subductions) and large-scale plumes (Vaughan and Scarrow, 2003; Moucha and Forte, 2011; Glisovic et al., 2012; Koptev et al., 2019).

The large-scale convection is strongly coupled with the motion of plates at the surface and thus the Africa-Eurasia relative motion. When a plate is attached to a subducting slab, it is powered by the slab pull force and when it is not attached to a slab it is powered by the mantle flowing underneath (Coltice et al., 2019) (Fig. 1). The Tethyan context is, however, complex because the shapes of margins are not simple and collision does not happen everywhere at the same period (Dercourt et al., 1986, Dercourt et al., 1993; Jolivet and Faccenna, 2000; Bellahsen et al., 2003), thus creating lateral variations of the slab pull force along the plate boundary and slowing down portions of continents that are then more easily coupled to the flow of mantle underneath.

The observed contemporaneity of compressional and extension periods over a wide domain encompassing a large part of Africa and western Europe has been explained by changes in the convection pattern with variations of the intensity of upwellings below South and West Africa and variations of the subduction regime below the northern margin of the Neo-Tethys Ocean (Jolivet et al., 2016a). In this model, the Late Cretaceous compressional period recorded in the Pyrénées and the obduction in Oman are the result of the penetration of the Tethyan slab through the boundary between the upper and lower mantle at a time of faster mantle upwelling in the south.

\subsection{Subduction-related metamorphism and subduction dynamics}

From the Late Cretaceous to the Eocene, HP-LT metamorphism has been recorded in most mountain belts except in the Pyrénées where syn-rift HT-LP metamorphism is instead observed (Ravier, 1959; Goldberg and Leyreloup, 1990; Clerc et al., 2015b; Ducoux et al., 2019). The absence of blueschists and eclogites in the Pyrénées can be due to the absence of a true subduction (Chevrot et al., 2014). In the Alps, the internal Apennines (Tuscan Archipelago) and the Betics instead, blueschist and eclogite-facies metamorphic overprints are recorded in large oceanic and/or continental units (Chopin, 1984; Goffé and Chopin, 1986; Goffé et al., 1989; Bousquet et al., 1997; Rossetti et al., 1999a, Rossetti et al., 1999b; Oberhänsli et al., 2004; Bousquet et al., 2008; Angiboust et al., 2009; Bianco et al., 2019; Agard, 2021). The oldest HP-LT metamorphism is recorded in the Eastern Alps with the Koralpe eclogites in the late Early Cretaceous $(\sim 100-110 \mathrm{Ma}$, Miller and Thöni, 1997). Otherwise, most of the blueschists and eclogites were formed in the Eocene (Oberhänsli et al., 2004; Bousquet et al., 2008). Ultra-high-pressure metamorphism is found in the Alps (Chopin, 1984) and in the Edough Massif (Algeria) (Bruguier et al., 2017). Available ages attributed to the peak of pressure along a given transect vary between $\sim 45 \mathrm{Ma}$ and 34-38 Ma and are nowhere younger than $34 \mathrm{Ma}$ (Duchêne et al., 1997b; Rubatto et al., 1997; Vitale Brovarone and Herwartz, 2013; Bruguier et al., 2017; Bessière, 2019; Bessière et al., 2021; Angiboust and Glodny, 2020, see also a synthesis in Agard, 2021). It is not always clear whether these ages really correspond to the peak of pressure, but they are nevertheless the youngest ages obtained from these tectonic units. In the Betics, the HP-LT metamorphism of the Alpujarride have been recently dated around $38 \mathrm{Ma}$ for the eastern and central parts (Bessière, 2019; Bessière et al., 2021). In the Nevado-Filabride also, $40 \mathrm{Ma}$ seems the age of the peak of pressure (Li and Massonne, 2018; Bessière et al., 2021). $34 \mathrm{Ma}$ correspond to the very end of the compressional period in Alpine Corsica (Beaudoin et al., 2020) and inception of rifting in the Liguro-Provençal basin and it falls just before the drastic change in the shortening regime in the French Alps with the first involvement of the External Crystalline Massifs and the flysch-to-molasse transition, associated with a retreat of the European slab (Vignaroli et al., 2009). We thus see a relation between the change of subduction regime at about 35-32 Ma in the Western Mediterranean and the end of H $P$-LT metamorphism, especially the fast exhumation of the UH $P$ units in the Alps and Edough Massif.

\section{Mediterranean Tectonics, between 32 and $8 \mathrm{Ma}$}

We divide this period of fast slab retreat in two episodes, before and after the inception of several major slab tears around 20-15 Ma (Fig. 12). 


\subsection{From 32 to $20-15 \mathrm{Ma}$}

This first period sees the opening of the Liguro-Provençal Basin and fast rotation of Corsica and Sardinia and the first stages of formation of the Alboran Sea at the expense of the Internal Zones of the Betics and Rif (Fig. 10), see Romagny et al. (2020) for detailed reconstructions. The Pyrenean orogenic wedge continues to form above the south Pyrenean front, while its eastern part is dismantled by rifting in the Gulf of Lion and leaves place to the passive margin (Jolivet et al., 2020). The extensional deformation reworking former mountain belts during slab retreat has been described previously; it is characterized by low-angle normal faults and associated basins. They are observed in the Betic Cordillera, in Calabria, in Tuscany and the Tuscan archipelago (Elba, Monte Cristo, Giglio, Gorgona) as well as in Corsica (Platt and Vissers, 1989; Jolivet et al., 1990; Keller and Pialli, 1990; Jolivet et al., 1991; Crespo-Blanc et al., 1994; Crespo-Blanc, 1995; Martinez-Martinez and Azañon, 1997; Jolivet et al., 1998; Rossetti et al., 2001; Platt et al., 2003a; Collettini and Holdsworth, 2004; Rossetti et al., 2004; Platt et al., 2013; Beaudoin et al., 2017). They are also observed within the Apennines with active normal faults with low-angle geometry (Collettini and Barchi, 2002; Brogi et al., 2003; Collettini and Barchi, 2004; Pauselli et al., 2006; Pauselli and Ranalli, 2017). A coeval migration of extension and magmatism is observed from Corsica toward the Apennines from the Miocene to the Present with east-dipping low-angle normal faults and exhumation of metamorphic core complexes (Jolivet et al., 1998). Present-day extension is active in the Apennines west of the water divide.

\subsubsection{Pre-drift position of Sardinia}

One still pending question is the pre-rift fit of Sardinia (Fig. 16). It is important for the understanding of the dynamics of rifting and also for the pre-rift kinematic restoration of the Pyrénées and their connection with the Provence fold-andthrust belt. The sharp bend of the North Pyrenean Thrust front across the Corbières may suggest that the entire crustal wedge was also bent, thus questioning the nature of the pre-rift basement below the Gulf of Lion passive margin. The continuity of the Pyrénées toward the east south of Provence before the Oligocene rifting has been discussed for a long time (Gorini et al., 1994; Mascle et al., 1994; Séranne et al., 1995; Séranne, 1999; Tavani et al., 2018). It is classically thought that a significant relief of Paleozoic basement existed south of Provence that was the backstop of the Provence fold-and-thrust belt. The main arguments (Arthaud and Séguret, 1981; Gorini et al., 1994; Guennoc et al., 2000; Bestani et al., 2015; Espurt et al., 2019) revolve around the presence of Pyrenean thrusts within the pre-rift basement on offshore seismic profiles as well as onland (Cap Sicié), the absence of any significant prerift sedimentary cover on top of the basement on seismic profiles in the Gulf of Lion, suggesting a period of aerial erosion, the pattern of paleocurrents showing a source of detritus south of Languedoc (BRGM et al., 1974; Christophoul et al., 2003; Vacherat et al., 2017) and the presence of Late Cretaceous conglomerate with a southern provenance in the southern part of Provence (Hennuy, 2003). The detailed offshore study of Fournier et al. (2016) shows the regional

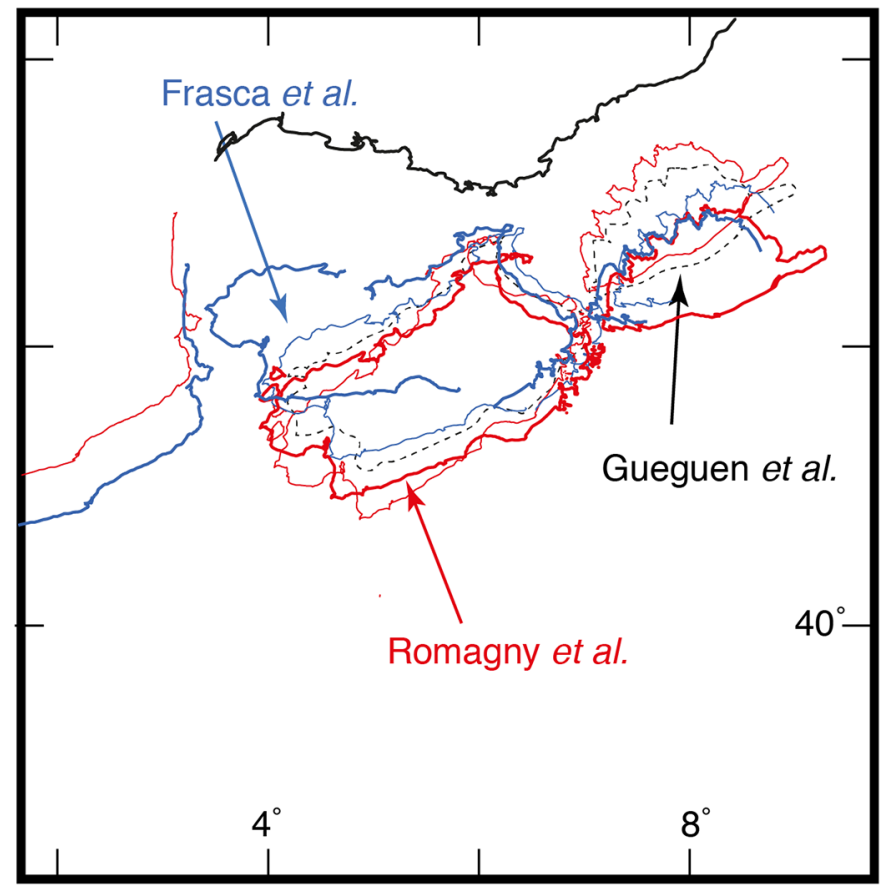

Fig. 16. Different options for the pre-rift fit of Sardinia before the rifting of the Gulf of Lion and opening of the Liguro-Provençal basin, after Romagny et al. (2020), Frasca et al. (2017) and Gueguen et al. (1998).

extension of the Cap Sicié Pyrenean thrust carrying a large Paleozoic basement unit and its Mesozoic cover, which could be the source of the detrital sediments shed over Languedoc with an eastern provenance. This conclusion is consistent with the findings of Ternois et al. (2019) who document the uplift of the Agly massif during the Late Cretaceous.

Before the rotation of Corsica and Sardinia, the Provence fold-and-thrust belt was the foreland of the Alpine Corsica accretionary wedge (Vially and Tremolières, 1996; Lacombe and Jolivet, 2005; Bestani et al., 2015). This question has been recently addressed by Romagny et al. (2020). If one considers Corsica-Sardinia as a rigid block following the earlier works of Arthaud \& Matte (1977), rotating it back to its pre-rift position leaves a "hole" at the emplacement of the Gulf of Lion. The $23 \mathrm{Ma}$ reconstruction of Gueguen et al. (1998) shows the situation at the end of rifting before the fast rotation and formation of oceanic crust (Fig. 16). The space left between Sardinia and the Languedoc coastline corresponds to the rifted crust underlying the Gulf of Lion margin and the amount of extension during rifting is not reconstructed. The solution chosen by Romagny et al. (2020) is to rotate back the rigid Corsica-Sardinia block so that the crust in the Gulf of Lion returns to a thickness of $30 \mathrm{~km}$, which corresponds to the present-day thickness below the coastline, based on the balanced cross-section of Jolivet et al. (2015a). Angrand et al. (2020) have adopted a similar reconstruction of the pre-drift position of Sardinia. Ford et al. (2020) have chosen an initial thickness of $40 \mathrm{~km}$ instead and they must then rotate more Sardinia than Corsica. They thus divided Sardinia in two blocks moving along a sinistral strike-slip fault during rifting. The two solutions are consistent with the possibility of a 


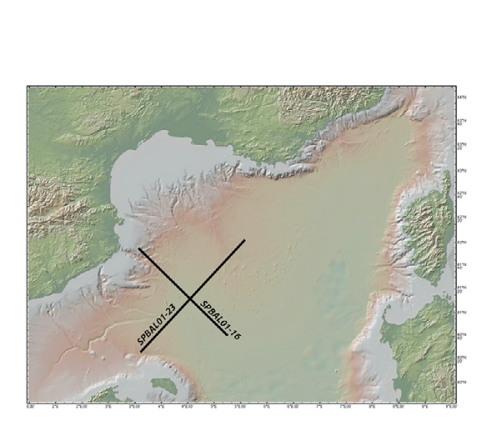

NNW

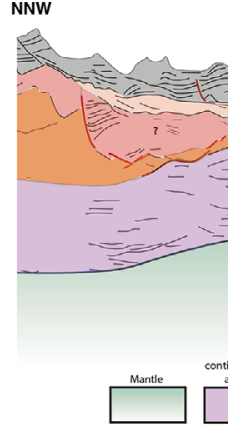

sw
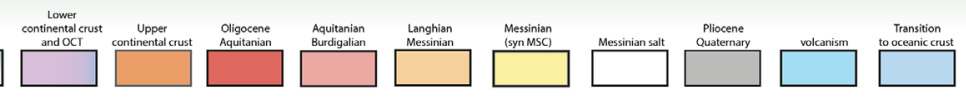

SPBAL01_23

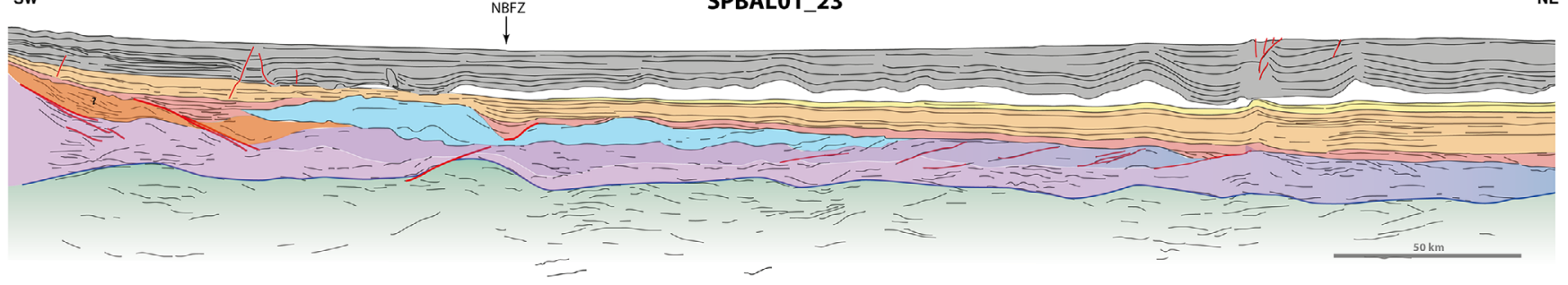

Fig. 17. Two interpreted seismic lines across the transition zone between the Valencia basin and the Gulf of Lion, after Jolivet et al. (2020) and Maillard et al. (2020).

subaerial erosion before rifting or at the time of rifting, but Ford et al. (2020) keep a thicker crust during a longer period. The difference in rotation angle is small and keeps within the error bars of paleomagnetic data and the additional motion of southern Sardinia does not involve much rotation. The accretionary wedge south of Provence in the Eocene involved Alpine and Variscan Corsica (Lacombe and Jolivet, 2005) but the thickness of the crust at that time is unknown. The absence of a thick foreland basin in Provence is not consistent with a thick crust. Both solutions are, however, consistent with the available data set and solve the solution of the "hole" at the emplacement of the Gulf of Lion but it is difficult to assess which fit is the best (see also Advokaat et al., 2014).

\subsubsection{Depth-dependent extension during back-arc rifting}

The question of the amount of extension during the rifting of the Gulf of Lion has long been debated. Bessis (1986) and Burrus (1989) observed that the amount of thermal subsidence during the post-rift period is compatible with a larger amount of stretching than shown by the moderate extension deduced from normal faults seen on seismic profiles. They also showed that fast thermal subsidence started very early after the end of rifting. Later studies based on seismic reflection profiles such as the ECORS experiment confirmed the intense thinning, and refraction data showed that the distal part of the margin is characterized by an abnormal crust with higher seismic velocities than normal continental crust, without the typical pattern of oceanic crust (Pascal et al., 1993; Chamot-Rooke et al., 1999; Gailler et al., 2009; Bache et al., 2010; Moulin et al., 2015). Based on the interpretation of wide-angle seismic profiles across the Liguro-Provençal Basin (Sardinia cruise 2006), Gailler et al. (2009) discussed the nature of the crust below the distal margin with two opposed hypotheses, either lower continental crustal material or a mixture of serpentinized mantle with lower crustal material. Bache et al. (2010) confirm that the amount of extension deduced from the observation of upper crustal normal faults can account for only a part of the finite stretching. Jolivet et al. (2012, 2015a) used an industrial seismic profile across the Gulf of Lion passive margin to argue in favor of exhumed lower continental crust and upper mantle from below the upper crust by the activity of low-angle detachments dipping toward the continent (Fig. 11). Based on further analyses of the Sardinia experiment, Moulin et al. (2015) and Afilhado et al. (2015) also argued in favor of exhumed lower crustal material for the distal margin. The presence of this exhumed lower crustal material on both the Provence and Sardinia sides led them to conclude that an asymmetric model with a single detachment is unlikely.

Additional information recently came from the analysis of a series of reflection profiles across the eastern part of the Valencia Basin in the transition zone with the Gulf of Lion. Granado et al. (2016) also interpreted the distal margin as made of lower crustal material extracted from below the margin by low-angle detachments. More recently, Jolivet et al. (2020) and Maillard et al. (2020) showed that the eastern part of the Valencia Basin is characterized by ductilely stretched lower continental crust with evidence of low-angle shear zones and covered with a thick pile of volcanic material emplaced during rifting (Fig. 17). The presence of this volcanic province had already been proposed earlier by Mauffret et al. (1995) and Maillard and Mauffret (1999). It makes a striking difference with the Gulf of Lion margin where little volcanic material is observed. Canva et al. (2020), however, showed that the prominent Catalan magnetic anomaly is best explained by the underplating of mafic material (gabbros) underneath the crust in the vicinity of the Catalan transfer zone (Figs. 18 and 19). The eastern Valencia Basin and the Gulf of Lion are thus both characterized by the exhumation of ductile lower crust during 


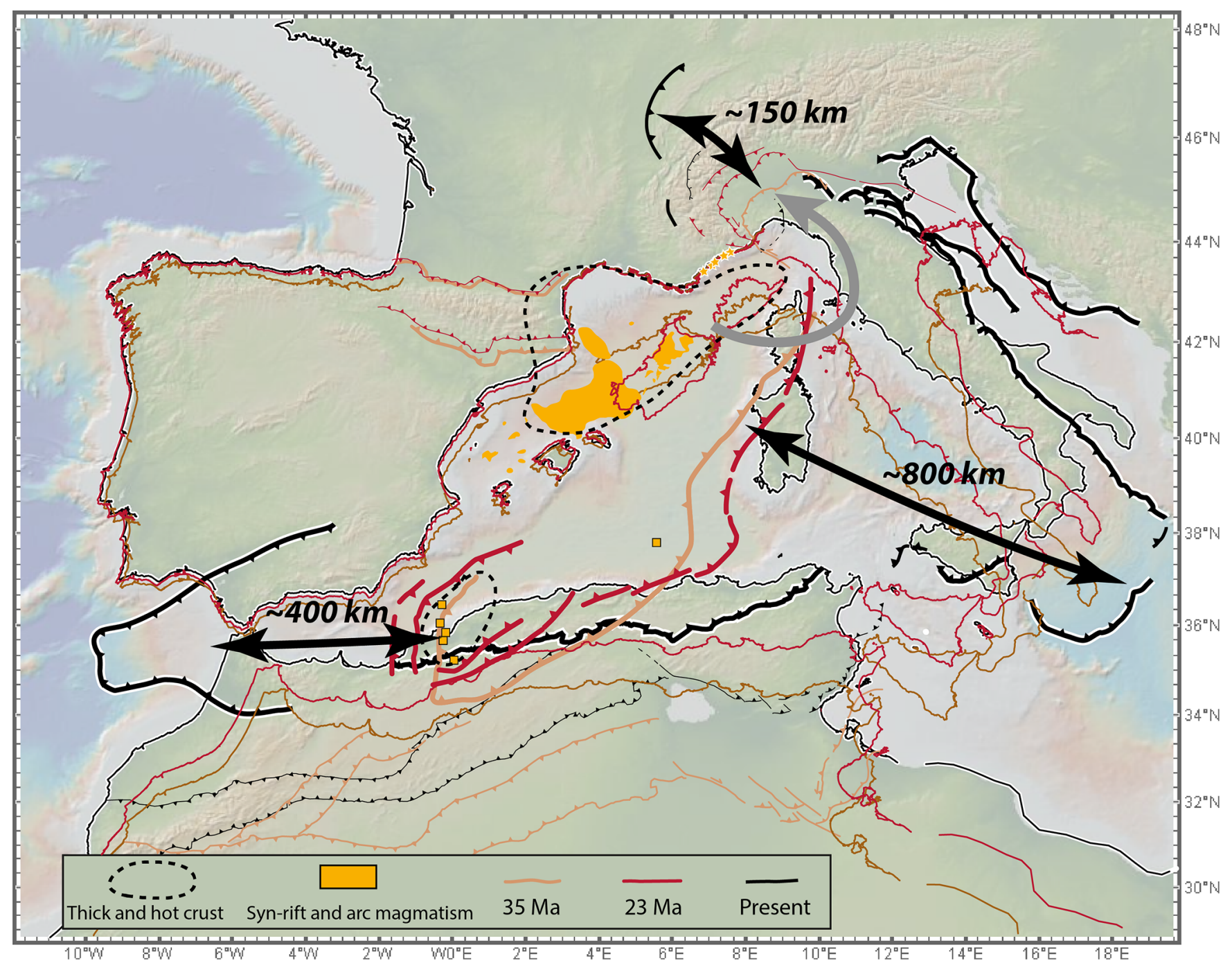

Fig. 18. Comparison of the positions of the subduction zone at $35 \mathrm{Ma}, 23 \mathrm{Ma}$ and present and the estimated displacements since $35 \mathrm{Ma}$. Orange color represents the extent of syn-rift volcanism, including the orange arrows along the southern coast of France that stand for the adakitic outcrops dated from the latest Eocene and early Oligocene (Réhault et al., 2012; Jolivet et al., 2020; Maillard et al., 2020). Thick dashed lines show the limits of thick and hot crust at the time of rifting. The grey curved arrow symbolizes the toroidal flow due to the retreat of the Apennines slab (Vignaroli et al., 2009).

rifting with the addition of intense volcanic activity in the Valencia Basin. The eastern Valencia Basin margin and the Gulf of Lion thus fall in the group of hot margins in the sense of Clerc et al. (2015a, 2016, 2017) and Jolivet et al. (2018), with differential extension in the upper and lower crust and shearing along the crust-mantle interface.

These recent findings led Jolivet et al. (2020) to reinterpret (Fig. 11) the significance of the recent receiver-function experiment across the Pyrénées (Chevrot et al., 2018; Diaz et al., 2018). A series of 5 profiles across the strike of the belts was recorded from west to east with the addition of a longitudinal profile in the Eastern Pyrénées. The three western profiles show a clear "orogenic" structure with the underthrusting of the Iberian crust below the Pyrénées and a very shallow Moho below the North Pyrenean Zone, especially below the Mauleon-Arzacq Basin way above the Iberian Moho. The shallow Moho is interpreted by Chevrot et al.
(2018) as an inheritance from the Early Cretaceous rifting event, the thin crust being passively transported by Pyrenean thrusts, which is confirmed by the results of the Maupasacq passive seismic experiment (Lehujeur et al., 2021). Toward the east, the situation changes drastically and this orogenic structure is lost with a shallower Moho and no clear image of the underthrusting of Iberia underneath the chain. Chevrot et al. (2018) interpreted this difference as inherited from the pre-orogenic template, namely two different geometries of the early Cretaceous rift. A parallel study showed that this region is characterized by an anomalous lithosphere that has lost its lower crust (Wehr et al., 2018). No observation is available to constrain the timing of the removal of the lower crust. An alternative interpretation of the receiver-function profiles was then proposed by Jolivet et al. (2020). The missing lower crust below the eastern Pyrénées would have been extracted from below the belt and juxtaposed with the distal part of the Gulf of 


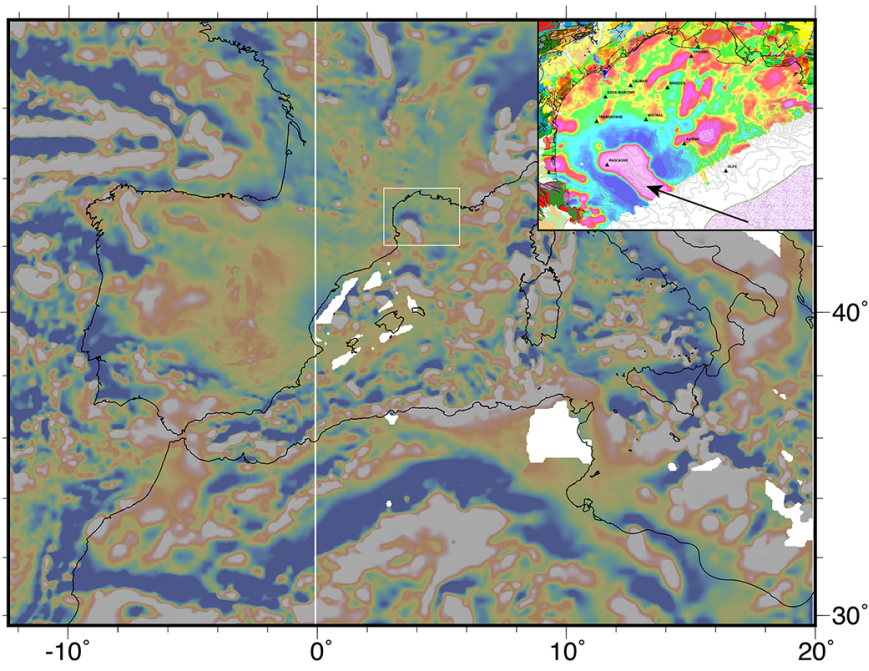

Fig. 19. Magnetic map of the Western Mediterranean (EMAG2-2013 -made from GeoMapApp; [Ryan et al., 2009]) and a zoom on the vertical gradient of the magnetic anomalies (reduced to the pole) in the Gulf of Lion, after Canva et al. (2020).

Lion margin (Fig. 11). The change from west to east of the deep structure of the Pyrénées would then be the result of postorogenic extension during the formation of the Gulf of Lion margin, instead of an heritage from the early Cretaceous rifting stage. This scenario has the additional advantage to explain the fast cooling episode recorded in the Eastern Pyrénées around $30 \mathrm{Ma}$ at the time of rifting based on low-temperature thermochronology data (Morris et al., 1998; Fitzgerald et al., 1999; Waldner et al., 2019; Daril, 2018; Bernard et al., 2019; 2020). More precisely Gunnell et al. (2009) constrain this episode between 25 and $35 \mathrm{Ma}$ and Maurel et al. (2002) around 26-27 Ma. Milesi (2020) also documents a period of exhumation after $35 \mathrm{Ma}$ and the exhumation of the footwall of the Têt fault after $30 \mathrm{Ma}$. The removal of the upper mantle from below the belt led to an uplift and the subsequent exhumation of the lower crust led to subsidence, which is recorded by the erosional unconformity seen on seismic profiles below the post-rift deposit (Bache et al., 2010; Jolivet et al. (2015a, 2015b)). The removal of upper mantle can be driven by basal shearing and it can also be a thermal consequence of slab retreat. The presence of a prominent erosion surface below the Aquitanian marine deposits contemporaneous of hyper-extension and final mantle exhumation (Bache et al., 2010; Jolivet et al., 2015a) shows that the entire margin was in subaerial conditions during rifting and was thus supported by a thin and hot lithosphere (Fig. 18). In addition, density reduction resulting from serpentinisation could help maintaining the surface of the lithosphere close to sea level (Huyghe et al., 2020). The Aquitaine foreland basin has recorded this transition toward post-orogenic extension with a hiatus and an erosional unconformity between the Chattian and the transgressive Aquitanian, that could be coeval with the erosional surface seen on seismic profiles of the Gulf of Lion margin (Ford et al., 2016; Ortiz, 2019; Calvet et al.,
2021; Ortiz et al., 2020). Low-T thermochronology data support the exhumation of the Eastern Pyrénées during the Late Oligocene (Fitzgerald et al., 1999; Maurel et al., 2002; Daril, 2018; Milesi, 2020) and the formation of planation surfaces, now at high elevation until the Late Miocene, also possible effects of mantle dynamics and/or magmatism during the early stages of extension (Gunnell et al., 2009; Monod et al., 2016; Calvet et al., 2021; Huyghe et al., 2020).

The main engine of crustal deformation during this period is the retreat of the slab subducting below the $\mathrm{AlKaPeCa}$ blocks and Corsica-Sardinia at the back. Finite displacements of retreating arcs amount to $800 \mathrm{~km}$ during this time interval, which implies that the asthenospheric mantle below the backarc region has also migrated by the same amount, thus inducing a significant flow below the extending lithosphere. One consequence is that the effects of slab retreat must be felt far away from the retreating trench in the back-arc region (Barruol and Granet, 2002; Lucente et al., 2006; Jolivet et al., 2009, 2020).

\subsubsection{Transfer zones}

The large rigid rotation of the Corsica-Sardinia block and the emplacement of oceanic crust and/or exhumed mantle in the Liguro-Provençal Basin implies the existence of large transfer zones accommodating differential rotation and extension between the Gulf of Lion and the eastern Pyrénées coastline and further south the Valencia Basin and Minorca (Figs. 10 and 14) (Maillard and Mauffret, 1999, Maillard and Mauffret, 2013; Pellen et al., 2016). Such transfer faults have been drawn on maps for kinematic reasons, but they had so far not been characterized by any specific structure, except for their link with an intense volcanic activity in the Valencia Basin (Maillard and Mauffret, 1999). Recent studies (Canva et al., 2020; Maillard et al., 2020) with new seismic lines and the study of magnetic anomalies show these transfer zones with more details and the kinematic reconstructions (Romagny et al., 2020) show the different domains separated by the transfer zones (Fig. 14) (see also Jolivet et al., 2021, for a synthesis of these transfer zones in the whole Mediterranean realm and Ford et al., 2021 for detailed reconstructions of the junction between the Pyrénées and Languedoc). The northeastern part of the Valencia Basin until the transition with the Gulf of Lion shows a thick sequence of volcanic rocks mainly emplaced during the rifting and also afterward until the Messinian (Maillard et al., 2020). This volcanic sequence rests on top of exhumed lower crust showing evidence for low-angle shear zones and ductile deformation. Some specific features are observed when crossing the putative transfer zones such as localized grabens and their sedimentary infill, as well as lower crust and mantle domes. These features show a transtensional deformation with a significant extensional component associated with the dextral motion during rifting and drifting. The Catalan magnetic anomaly shows a trend parallel to the Catalan Transfer Zone and the work of Canva et al. (2020) (Fig. 19) has shown that it can be modelled with the underplating of mafic rocks (gabbros) along the trace of the anomaly. Dextral motion with a significant extensional component and magmatic additions at depth thus characterize these transfer zones. 


\subsubsection{Interactions of slabs at depth}

During this period, the Alboran domain was located eastward of its present position and the Alpujarride metamorphic complex was being exhumed from below the MalaguideAlpujarride Contact (MAC), a large-scale detachment with a top-to-the NE kinematics (Lonergan and Platt, 1995; Platt et al., 2005; 2013), until the docking of the AlKaPeCa block with the northern margin of Africa. H $P$-L $T$ metamorphic units of the Alpujarride were exhumed contemporaneously all the main blueschists units around the Western Mediterranean, including the Alps, Alpine Corsica, Calabria and the Kabylies. $38-34 \mathrm{Ma}$ is the time of the last peak pressure recorded in all these HP-L $T$ terranes (see above) (Fig. 20). Afterward, lowerpressure blueschists are still recorded east of Corsica in the early Miocene in the islands of Gorgona or Elba during the eastward retreat of the slab (Jolivet et al., 1998; Rossetti et al., 1999a, Rossetti et al., 1999b, Rossetti et al., 2004; Bianco et al., 2019).

The case of the Betics requires some discussion. The age of the peak pressure conditions in the Nevado-Filabride Complex is debated. Originally considered Eocene like in the Alpujarride (Monié et al., 1991; Augier et al., 2005a, Augier et al., 2005b), it was then assigned to the Early Miocene (until 16-17 Ma) based on dates obtained with the Lu-Hf method on garnet (Platt et al., 2006), the U-Pb method on zircons (López Sánchez-Vizcaíno et al., 2001; Gómez-Pugnaire et al., 2012) or $\mathrm{Rb}-\mathrm{Sr}$ isochrons (Kirchner et al., 2015). More recently, however, $\mathrm{U}-\mathrm{Pb}$ ages around $40 \mathrm{Ma}$ were obtained on monazite (Li and Massonne, 2018). Bessière et al. (2021) then consider that these Early Miocene ages correspond to the late exhumation of these units and that the peak of pressure was indeed Eocene. The end of exhumation of well-preserved $\mathrm{H} P$ or UHP units around 38-34 Ma thus occurred just before or at the time of inception of back-arc rifting in the Gulf of Lion and Alboran Sea and the beginning of slab retreat. Afterward, only lower pressure conditions were attained with locally HP-LT conditions such as in the Tuscan archipelago (Jolivet et al., 1998; Rossetti et al., 1999a, 1999b; Bianco et al., 2015, 2019). This suggests that the inception of slab retreat changed the dynamics of subduction channels where these $\mathrm{H} P$-L $T$ metamorphic rocks were formed (Jolivet et al., 2003). This is quite straightforward for the areas directly impacted by back-arc extension, but more surprising for the Alps where this period instead corresponds to the westward propagation of the thrust front and the westward overthrusting of the External Crystalline Massifs at around $32 \mathrm{Ma}$, before the stacking of the Subalpine domain in the middle Miocene (Ford et al., 2006; Bellahsen et al., 2014; Bellanger et al., 2015). It also corresponds to an evolution of the flexural basin with the flysch-to-molasse transition and an increase of the volume of sediments shed in these basins (Kuhlemann et al., 2002; Kuhlemann and Kempf, 2002).

These coeval evolutions of the back-arc domain and of the Alps is symptomatic of the possible interactions of the Alpine and Apennines slabs at depth. As proposed by Vignaroli et al. (2008; 2009), the eastward retreat of the Apennines slab might have forced a counter clockwise toroidal flow of the asthenospheric mantle trapped beneath the Apenninic slab (Figs. 14 and 18), which has then pushed the east-dipping European slab westward, thus opening the subduction channel and favoring the exhumation of $\mathrm{H} P$-L $T$ metamorphic rocks and accelerating the rate of subduction in the external zones of the French-Italian Alps. The change of subduction regime would then have induced changes in the dynamics of mountain belts all around the Western Mediterranean.

While the Alps, the Eastern Pyrénées or the Betics show sharp changes at around 35-32 Ma, the Western and Central Pyrénées simply record continuing southward propagation of thrusts in the Ebro foreland basin until the early Miocene (Jolivet et al., 2007; Mouthereau et al., 2014; Bosch et al., 2016; Labaume et al., 2016; Teixell et al., 2018;). The peak of exhumation recorded in the Eastern Pyrénées is around $30 \mathrm{Ma}$ (Daril, 2018). It is younger in the west, around 25-20 Ma with also a more recent deformation in the south (Bosch et al., 2016). The central Pyrénées would show a continuous sequence of deformation (Mouthereau et al., 2014). This longitudinal evolution of the Pyrénées could possibly be also a consequence of the mantle flow due to slab retreat underneath that would have eroded the western part only after the eastern part, but the geometry of the belt at depth in the center and west does not comfort this hypothesis. The effect of rifting in the Gulf of Lion was thus seemingly not felt in the western part of the belt where compressional stresses transferred through the lithospheric stress-guide from the Africa-Iberia plate boundary were predominant. This suggests a maximum distance in the influence of slab retreat and associated asthenospheric flow on the overriding plate.

During this period, slab retreat was the primary engine of crustal deformation in a wide domain including the immediate back-arc regions and their hinterlands, including part of the Eastern Pyrénées and also the Alps, which dynamics was strongly modified by the interactions between slabs.

\subsection{Between $20-15$ and $8 \mathrm{Ma}$}

During this later period, slab tearing goes on with a focalization on two narrower slabs (one retreating westward - Gibraltar, one eastward - southern Tyrrhenian Sea) after an episode of tearing following the collision of AlKaPeCa with the northern margin of Africa (Figs. 10 and 13). An additional ingredient should be considered to explain the change in the dynamics of subduction around $15 \mathrm{Ma}$. Based on analogue experiments, Faccenna et al. (2001a, 2003) suggested that the interaction of the slab with the upper-lower mantle transition zone had slowed down the retreat during a short period, stopping the opening of the Liguro-Provençal and rotation of the Corsica-Sardinia block and initiating the rifting of the Tyrrhenian Sea. An alternative could be that the collision of AlKaPeCa with Africa had stopped the rotation of Sardinia. The width of the Apennines slab progressively narrows through time and the velocity of retreat consequently increases (Carminati et al., 1998a, 1998b). The most recent slab is indeed very narrow and the velocity of retreat was high $(10 \mathrm{~cm} /$ $\mathrm{yr}$ in average) during the Pliocene (Royden et al., 1987; Patacca and Scandone, 1989; Patacca et al., 1990; Faccenna et al., 2005; Guillaume et al., 2010).

The western part of the torn slab retreats westward, forming the Alboran Sea and transporting the West Alboran Basin (Crespo-Blanc et al., 2016; Do Couto et al., 2016). This westward motion of the Alboran domain is limited by two 


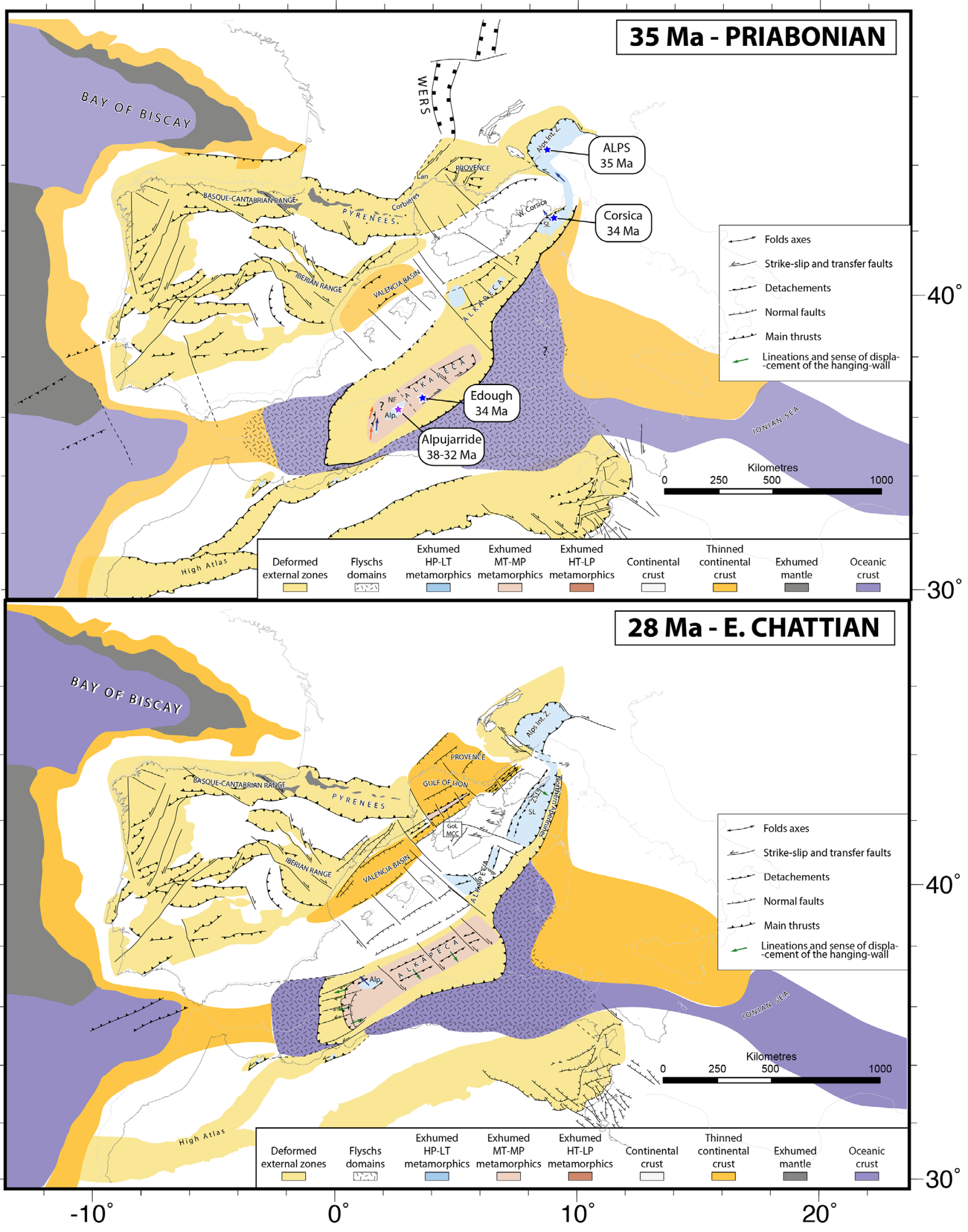

Fig. 20. Reconstructions (Romagny et al., 2020) at $35 \mathrm{Ma}$ and $28 \mathrm{Ma}$ of the Western Mediterranean at the transition between compression and extension in the Gulf of Lion region and right after the beginning of back-arc extension. Ages of the UHP-LT and HP-LT peak pressure conditions are shown on the $35 \mathrm{Ma}$ stage, after Gebauer et al. (1997), Rubatto et al. (1997), Duchêne et al. (1997a), Vitale-Brovarone and Herwartz (2013), Bruguier et al. (2017) and Bessière (2019). 
transfer zones where the relative motion is mostly strike-slip, dextral on the Betic side and sinistral on the Rif side (see also Romagny et al., 2020; Jolivet et al., 2021). Retreat of the Alboran slab proceeds along the northern margin of Africa and the strike-slip component is distributed through wide transfer zones on the northern and southern margins of the Alboran basin. This strike-slip component is accommodated by E-W trending strike-slip faults but mostly by E-W extension on lowangle normal faults and ductile detachments, the largest of which being the Filabres Shear Zone that has exhumed the Sierra Nevada-Sierra de los Filabres MCC (Jabaloy et al., 1993; Augier et al., 2005a). These domes are elongated parallel to the main direction of shearing, making them a-type domes (Jolivet et al., 2004) that can be modelled numerically in 3-D within transtensional shear zones (Le Pourhiet et al., 2012).

In the same period, oceanic crust was emplaced in the Algerian Basin (Mauffret et al., 2004; Booth-Rea et al., 2007; Driussi et al., 2015) and strong crustal thinning affected the Alboran Basin and the West Alboran Basin formed by passive subsidence above the steeply-dipping slab following its westward migration (Do Couto et al., 2016).

During this period the main engine was again slab retreat which direction was almost perpendicular to the AfricaEurasia convergence. Because the slab progressively unzipped westward until the longitude of the Gibraltar Strait, this situation might also lead to a decrease of compressional stresses across the Alboran Sea and thus a progressive relaxation of compressional stresses across Iberia and the Pyrénées, the latter entering a post-orogenic stage.

\section{Late-Mediterranean Tectonics, from $8 \mathrm{Ma}$ to the Present}

$8 \mathrm{Ma}$ was a major change in the tectonic evolution of the Alboran region with the slowing down of the westward retreat of the slab beneath Gibraltar and a transition from dominant E$\mathrm{W}$ extension to dominant $\mathrm{N}-\mathrm{S}$ shortening, although a component of NE-SW extension is still felt today west of the Sierra Nevada (Galindo-Zaldıvar et al., 2003; Pérez-Peña et al., 2010). The N-S shortening is accompanied by the formation of large crustal-scale folds in the Eastern Betics that amplify the MCCs exhumed during the preceding period (Sierra Nevada, Sierra Alhamilla, Sierra de Gador) (Weijermars et al., 1985; Sanz de Galdeano and Vera, 1992; Meijninger and Vissers, 2006; Augier et al., 2013; Janowski et al., 2017) and by the initiation of the left-lateral TransAlboran Shear Zone and associated magmatism (Hernandez et al., 1987; de Larouzière et al., 1988; Stich et al., 2006; Estrada et al., 2017; Lafosse et al., 2018; d'Acremont et al., 2020; Lafosse et al., 2020) (Fig. 2). This N-S shortening is progressively felt all over the North African margin and it corresponds today to the compressional earthquakes and active faults mapped offshore (Deverchère et al., 2003; Billi et al., 2011; Martínez-García et al., 2017; d'Acremont et al., 2020; Lafosse et al., 2020) (Figs. 3, 4 and 10). The direction of shortening is N-S or NNW-SSE in the south (High Atlas) and the rate of uplift increases after $6 \mathrm{Ma}$ (Frizon de Lamotte et al., 2000; Benaouali-Mebarek et al., 2006; Babault et al., 2008; Lanari et al., 2020a, 2020b) and becomes more NW-SE in the north (France) (Cornet and Burlet, 1992; Dèzes et al., 2004;
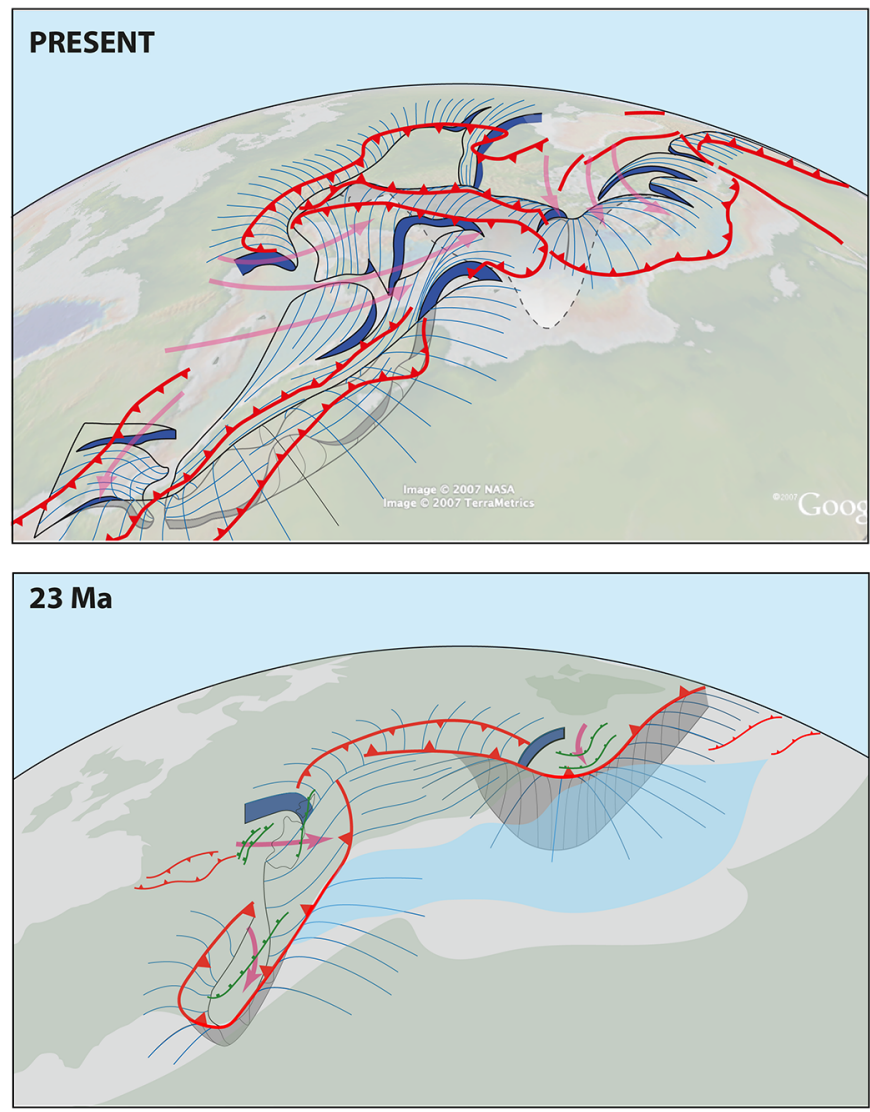

Fig. 21. Two schematic reconstructions in 3-D of the Mediterranean region showing the geometry of slabs during and after the back-arc extension and slab retreat episode, completed from Jolivet et al. (2009).

Baize et al., 2013). Not all the uplift of the Atlas is a consequence of shortening and significance part is due to mantle upwelling there (Babault et al., 2008; Missenard and Cadoux, 2012). Shortening is radial in the frontal zones of the Apennines. Extension remains active with frequent earthquakes in the internal Apennines all the way to the crestline (Amato et al., 1993; D'Agostino et al., 1998) and it is also active in the internal parts of the southern Alps (Sue and Tricart, 1999; Sue et al., 1999; Delacou et al., 2004; Walpersdorf et al., 2018; Sternai et al., 2019). It is also active in the southeast Tyrrhenian Sea with fast slab retreat until the end of the Pliocene (Sartori et al., 2004; Prada et al., 2014, Prada et al., 2018). Whether it is still active today is debated. Zitellini et al. (2019) recently brought observations in favor of a compressional reactivation of the southern Tyrrhenian Sea during the Pliocene, while Gutscher et al. (2017) describe active deformation in the Calabrian accretionary wedge, suggesting that subduction is still active.

Figure 10 shows the evolution of the stress regime in the Western Mediterranean region. The post- $8 \mathrm{Ma}$ configuration is similar to the pre-32 Ma one except for the southern Tyrrhenian Sea where compression is more recent (Zitellini et al., 2019). The main changes are recorded in the west where Africa is fully recoupled with northern Europe. The whole Western Mediterranean is now dominated by N-S compression, returning to the pre-32 Ma situation, before slab retreat started. 
L. Jolivet et al.: BSGF 2021, 192, 48
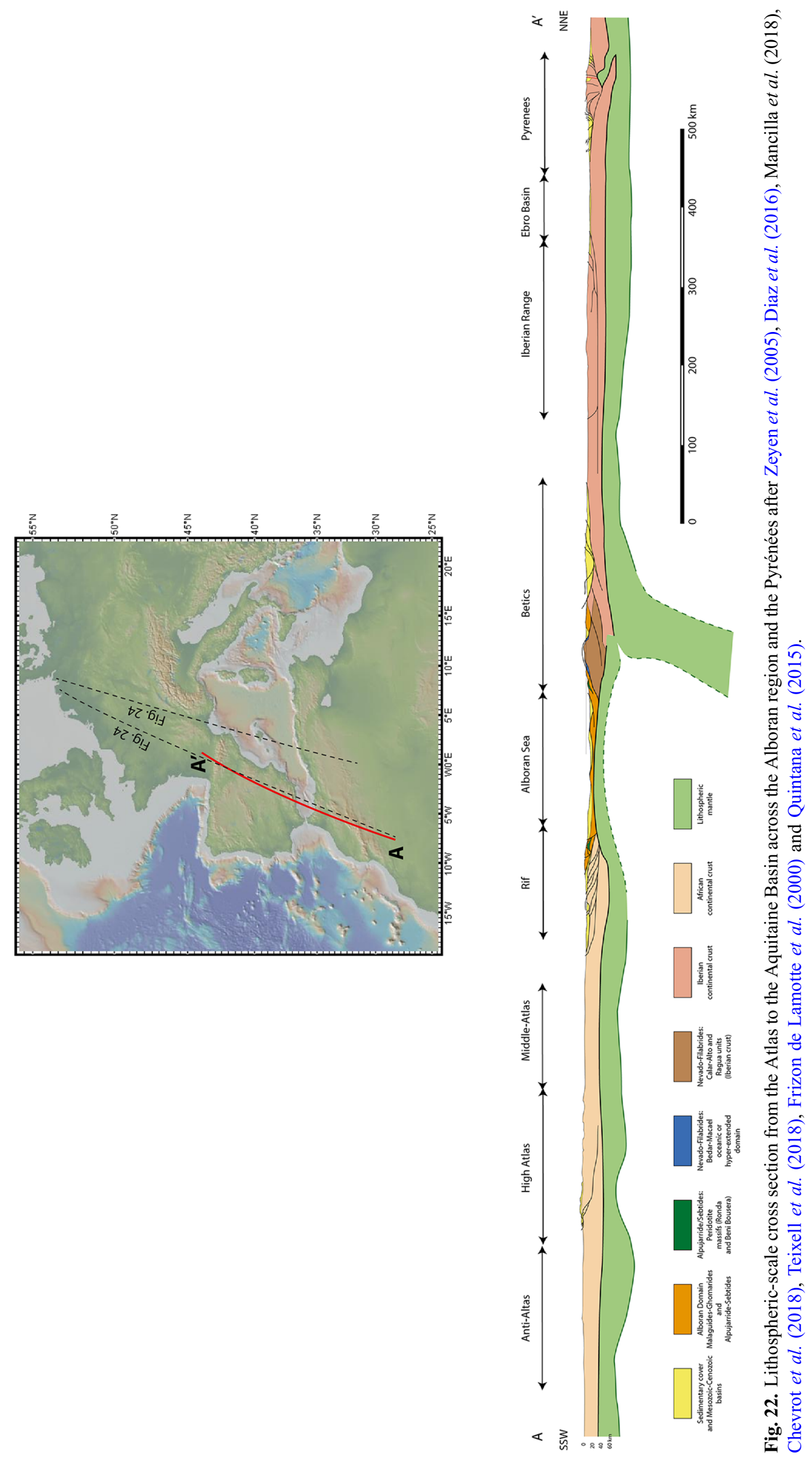

Page 30 of 49 
This renewed compression has been proposed as the trigger for the onset of the Messinian Salinity Crisis as it would have progressively severed the connections between the Atlantic Ocean and the Mediterranean (Jolivet et al., 2006). Spakman et al. (2018) and Capella et al. (2019) further proposed that the recent evolution is a consequence of the dragging of the slab hanging below the Western Alboran region by the absolute motion of Africa and Eurasia. This proposition is based upon a 3-D numerical modelling of the behavior of the hanging slab (Chertova et al., 2014) and a good fit of the outcome with observations of active displacements and deformation in the Alboran realm. Then, the resumption of N-S shortening is not restricted to the western Alboran region. It instead affects the whole North African margin, the whole of the Atlas from west to east and progressively most of the western Mediterranean except for the Apennines (Frizon de Lamotte et al., 2000, 2008). An additional mechanism must then be looked for (see below).

\section{Discussion, far-field versus near-field interactions}

We now summarize and discuss further these evolutions in terms of forces, attempting at separating the near-field and farfield interactions, which are due to lithospheric-scale or crustal-scale transmission of stresses versus deeper contributions, mainly mantle flow due to large-scale convection and/or slab retreat. Numerical models of mantle convection with lithospheric plates show that slabs play a major role in mantle flow. Coltice et al. (2019) show that plates attached to a subducting slab are the fastest and they are mainly powered by slab-pull (Fig. 1). The lithosphere in this case moves faster than the mantle underneath. Plates not attached to a subducting slab are moved and deformed by the mantle flowing faster underneath. In plate convergence areas, slab retreat then becomes a major driver of deformation of the overriding plate. The Mediterranean region during the Mediterranean Tectonics stage is typical of the latter behavior and crustal deformation of back-arc region is driven to a large extent by the flow of mantle due to slab retreat (Fig. 21).

We focus our discussion on several lithospheric sections running from the Atlas Mountains to the North Sea (Figs. 22 and 23). Figure 22 shows a section from the Atlas to the Pyrénées showing crustal and lithospheric thickness variations based the works of Zeyen et al. (2005), Diaz et al. (2016), de Lis Mancilla et al. (2018), Chevrot et al. (2018), Teixell et al. (2018), Frizon de Lamotte et al. (2000, 2008) and Quintana et al. (2015). A detailed lithospheric section of the whole Western Europe is also proposed by Mouthereau et al. (2021) based on seismic reflection lines and informed by geophysical constraints for lithosphere thickness. Figure 23 is more schematic and includes the section of Figure 22 in a larger framework, all the way to the North Sea with additional data from Cloetingh et al. $(2009,2010)$. These two sections show that the compressional stresses that lead to the formation of the Rif, the Betics, the Iberian Range and the Pyrénées were set on a rather thin lithospheric lid carrying a crust of normal thickness. Oligo-Miocene extension has thinned the crust and the lithosphere in the Alboran Sea and its margins afterward. The thickest lithosphere is found at the extremities of the system, below Northern Europe and North Africa. Compression was felt as far as the North Sea at a distance that is equivalent to that between the Pyrénées and the Atlas.

On Figure 23, we show the different types of forces that may have controlled this tectonic evolution. Compression arising from the convergence between Africa and Eurasia (black arrows) has been transmitted horizontally through the lithospheric stress-guide. In addition to convergence, some more horizontal compression can be provided by the Alpine collision and by the Iceland plume. Crustal thickening has locally modified the lateral distribution of densities, generating body forces (blue arrows) that can lead to crustal spreading. Probably not significant in the Pyrénées, this type of body forces has played an important role in the Miocene evolution of the Alboran region (Platt and Vissers, 1989; Vissers et al., 1995). The slab now dipping underneath the Gibraltar Arc has a complex history of southward-then-westward retreat that has largely controlled the deformation all around the Alboran Sea (green and orange arrows). This slab dynamics includes the asthenospheric flow created by slab retreat (orange arrows). The large-scale convection carrying the large plates northward also played a significant role (red arrows).

We have then constructed a series of cross-sections showing the evolution of this region through time from the early Cretaceous (110 Ma) to the Present (Fig. 24) emphasizing the role of each type of forces. We now discuss the interactions of these different forces (Figs. 9, 10 and 24).

During the Tethyan Tectonic stage, the Western Mediterranean region lies between the the westernmost Tethys (lato sensu) and the actively opening Atlantic Ocean and it reacts to external solicitations due to the lithospheric-scale interactions between Africa, Eurasia, Adria/Apulia and Iberia and the interactions with the convecting mantle underneath. From the Late Jurassic to the Early Cretaceous (Tethyan I), the entire domain from West Africa to Northern Europe is under extension. The Pyrenean and Iberian rifts open during this period and Apulia rifts away from Africa in the Late Triassic and early Jurassic. This distributed extension is coeval with the opening of Central Atlantic and from the Lower Cretaceous also the South Atlantic. The African plate is driven both by the slab-pull in the northern Tethys subduction zones and by the plume in the south. Extension is caused simply by the oblique divergence between Africa and Eurasia and/or by the flow of mantle underneath Africa that leads to the separation of Apulia from Africa. This pattern is permanent during the whole history of the Tethys, from the PaleoTethys to the Neo-Tethys and even the present situation (Fig. 15). The long-term presence of a plume above the Tuzo large low-shear velocity province (Burke and Torsvik, 2004; Burke et al., 2008) could explain this permanent behavior, typical of the Tethys Oceans across time (Fig. 15).

Similarly, the generalized compression observed in the Late Cretaceous (Tethyan II) from Africa to northern Europe must be due to a large-scale process ultimately leading to the southward obduction of oceanic crust on the northern margins of Apulia (Izmir-Ankara suture zone) and Africa (Oman ophiolite), along several tens of thousands of kilometers, at least from the Aegean region to Oman and probably farther east in the future Himalaya (Jolivet et al., 2016a). This event can simply be a consequence of the convergence between Africa and Eurasia that started some $84 \mathrm{Ma}$ ago, but evidence 


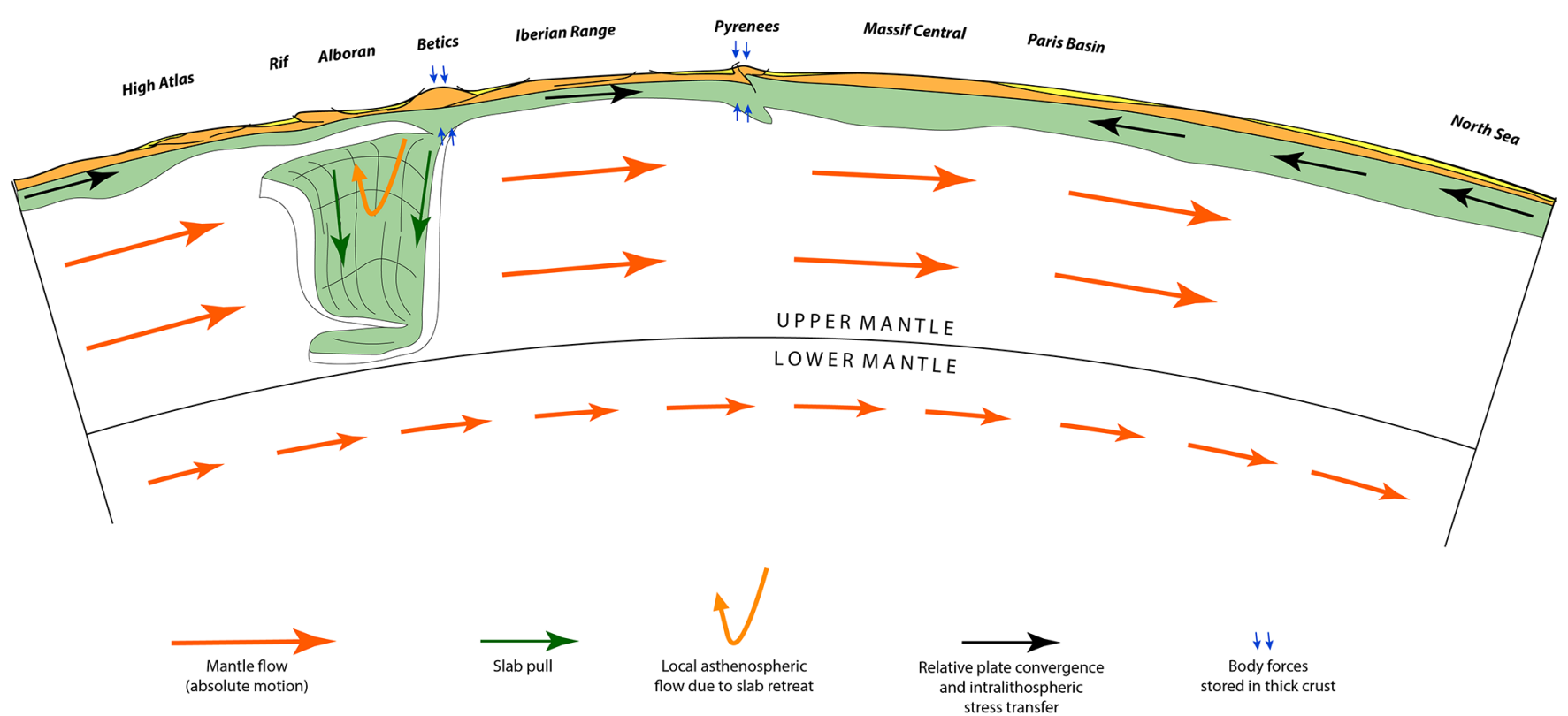

Fig. 23. Schematic section at lithospheric scale (topography not to scale) from the High Atlas to the North Sea showing the various forces driving the kinematics and deformation.

for compression and obduction started earlier around $100 \mathrm{Ma}$, $84 \mathrm{Ma}$ being the culmination of shortening (Guiraud et al., 2005; Jolivet et al., 2016a). An alternative solution is that this stress regime change was partly due to the interaction between the Tethys oceanic slab and the upper-lower mantle transition zone, which in turn induced the kinematic change. The nature of the subducting lithospheres and especially the behavior of the thick lithosphere of cratonic areas is also an important point to consider (Mouthereau et al., 2021). In this framework, the initiation of compression in the Pyrénées would be a part of a larger-scale process involving the whole mantle, and the kinematic change a consequence of these deep interactions. The progressive localization of strain along the Pyrenean thrusts has modified the distribution of stress and strain through time and space (Dielforder et al., 2019) but would then be a second order feature, at this large scale.

After $84 \mathrm{Ma}$ (Tethyan III), compression in the Western Mediterranean lasts until $35 \mathrm{Ma}$. In the Eocene, compression is recorded from the High Atlas in the south to the North Sea. The whole system from North Africa to the North Sea is coupled. The Pyrénées and the Betic-Rif orogens form in this context of generalized shortening over a large distance, coeval with the Dinarides and the Hellenides further east. In the eastern Mediterranean and Middle East, the Tethyan subduction creates back-arc basins in the overriding plate, suggesting a different subduction behavior. The observed compression in the west certainly owes much to the compressional stresses transmitted through the lithospheric stress guide between Africa and Eurasia. But, given the scale of the domain recording this compression, a larger-scale cause (mantle) is likely.

The Priabonian is a transitional period with continuing shortening in the Pyrénées and some limited extension in the West European Rift System. It represents also the last record of UH $P$ metamorphic rocks and the beginning of fast exhumation of all HP-LT metamorphic units, from the Alps to the Betics, suggesting a change of subduction dynamics. Whether the rifting in the West European Rift System is related to this change in subduction dynamics or a more local process is an open question. Merle and Michon (2001) proposed that this episode of rifting could result from the downward pull of the Alpine lithospheric slab inducing a counter flow of the asthenosphere and extensional stresses in the subducting lithosphere. In subsequent periods (Mediterranean Tectonics), compression is recorded only along the front of mountain belts forming above retreating slabs, including the Alps. The rest of the Western Mediterranean is under extension, powered by the retreat of the slab. Shortening progressively stops in the Pyrénées and the eastern part of the belt is dismantled and replaced by the Gulf of Lion passive margin (Jolivet et al., 2020). An alternative interpretation is to consider that the compressional deformation has migrated southward to concentrate in the Betics and the Rif with a progressive reduction of shortening in the Pyrénées (Daudet et al., 2020).

The slab first retreats southward and then westward and eastward after a major slab tear consecutive to the docking of the AlKaPeCa with the North Africa Margin some $20 \mathrm{Ma}$ ago (Leprêtre et al., 2018; Romagny et al., 2020). The counter clockwise rotation of the Corsica-Sardinia block and the progressive subduction of Adria in a retreating trench are coeval with the formation of the Liguro-Provençal and Tyrrhenian basins. The retreat of the Apennines slab induces a counterclockwise toroidal flow under the slab and this flow in turn pushes the Alpine slab westward, inducing the propagation of the thrust front and the exhumation of the External Crystalline Massifs, as well as compressional stresses in the Alpine foreland (Vignaroli et al., 2008). This situation lasts until the Late Miocene, around $8 \mathrm{Ma}$, when compression resumes and Africa and Eurasia are coupled again in the Western Mediterranean. Extension still prevails until very recently only where back-arc extension is still active, namely the South Tyrrhenian Basin as well as the Apennines. 

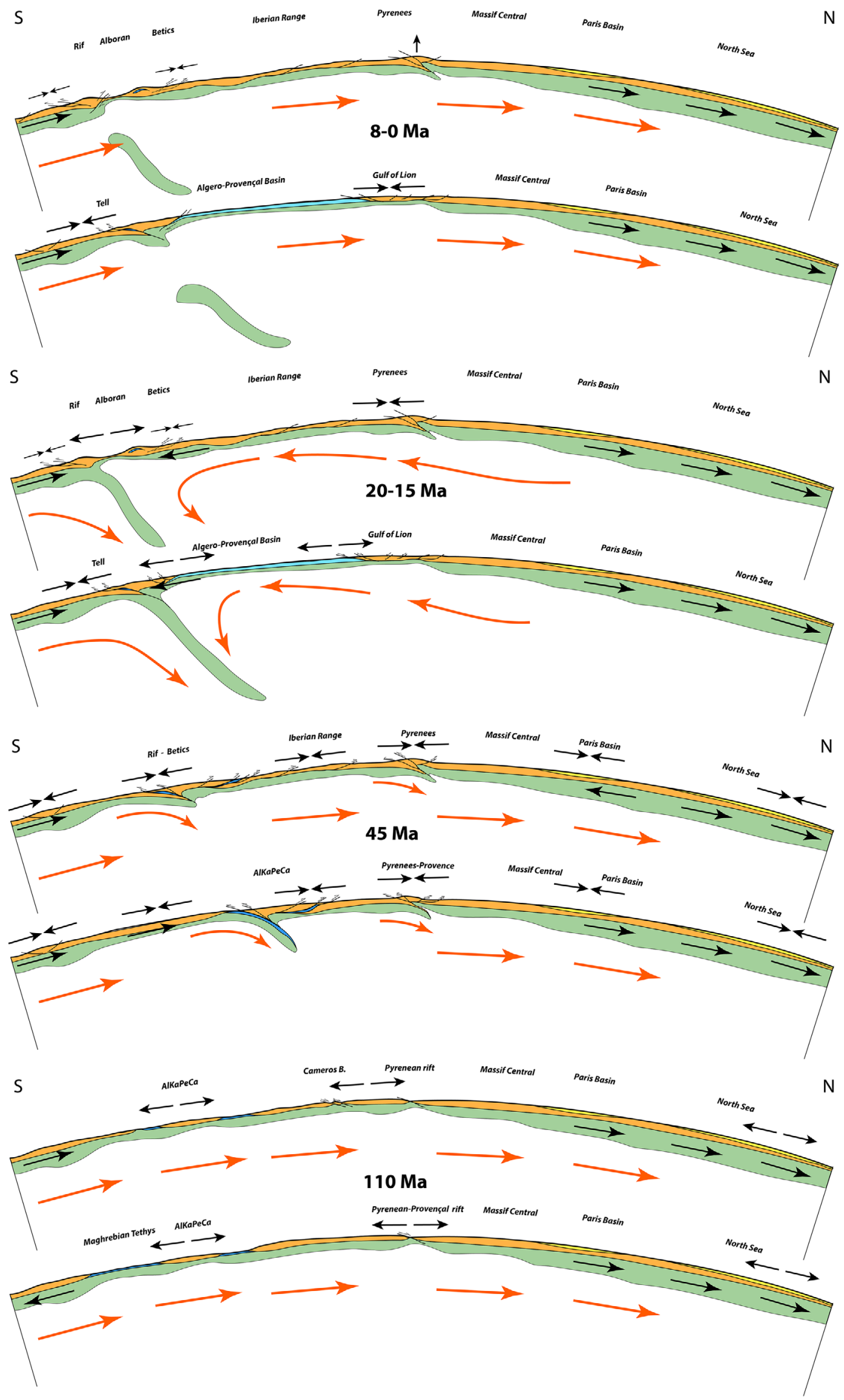

Fig. 24. Evolution of two cross-sections (locations on Fig. 22) from $110 \mathrm{Ma}$ to 8 Ma showing the succession of stages with the driving forces. 
After the Late Miocene and until Present (Late Mediterranean Tectonics), the stress regime in the Western Mediterranean returns to a situation quite similar to what it was in the Eocene prior to the initiation of slab retreat with N-S compression everywhere from the Atlas to the North Sea. This suggests that the slab retreat and related asthenospheric flow had decoupled Africa and Eurasia in this region as the flow of mantle was much faster than the Africa-Eurasia convergence and controlled the deformation in the back-arc region. It is only once the rate of retreat had significantly decreased in the west that N-S compression was felt again (Fig. 25). Dragging of the slab by the absolute motion of Africa and Eurasia (Spakman et al., 2018) adds its effects to control the observed stress and strain field in this region. The situation in the Pyrénées is partly unclear at this period. Geomorphological markers and thermochronology show evidence for uplift after $10 \mathrm{Ma}$, which causes are not obvious. It does not seem to be associated with a clear renewal of compression. A change in the mantle has been proposed by Gunnell et al. (2009) and Calvet et al. (2021), but this period should be studied in more details to unravel this important question.

\section{Conclusion}

This review shows the evolution of the geodynamic framework of the Western Mediterranean since the Early Cretaceous and the respective contributions of local (nearfield) and distant (far-field) forces. We distinguish three periods that reflect changes in the source of driving forces: (i) Tethyan Tectonics (150-35 Ma) when all deformations are driven by the relative motion of large plates and the large-scale convection underneath, from rifting to convergence. This period is further divided in Tethyan I (first rifting), Tethyan II (second rifting) and Tethyan III (convergence and shortening). (ii) Mediterranean Tectonics (35-8 Ma) when all deformations are under the control of slab retreat and (iii) Late-Mediterranean Tectonics (8-0 Ma) when slab retreat progressively stops and the situation return to the Tethyan stage with stress transmission across the whole plate boundary zone, from Africa to Europe, and large-scale mantle convection is again the main driver.

During the pre-35 Ma (Tethyan Tectonics) period the Western Mediterranean orogens are controlled by the largescale relative motions of Africa, Iberia and Eurasia and the mantle flowing underneath (large-scale convection). Early Cretaceous extension is distributed between Africa and the North Sea with a focalization within a wide plate boundary encompassing the future Rif-Betics arc, the future Iberian ranges and the Pyrenean rift basins. It is a consequence of the opening of the Atlantic Ocean and Bay of Biscay and of the long-term evolution of the Tethys Ocean involving the northward flow of mantle due to large-scale convection. From the Late Cretaceous, the relative motion of African and Eurasia becomes convergent and compression ensues. It is recorded from the reactivated early Cretaceous African rift basins all the way to the North Sea. This phase of compression culminates in Africa at $84 \mathrm{Ma}$ and it leads to the obduction of ophiolite nappes on the northern margins of Apulia and Africa. The scale of this compressional domain and the specific characteristics of large-scale ophiolite obduction suggests that whole mantle is involved in this change of regime and models involving

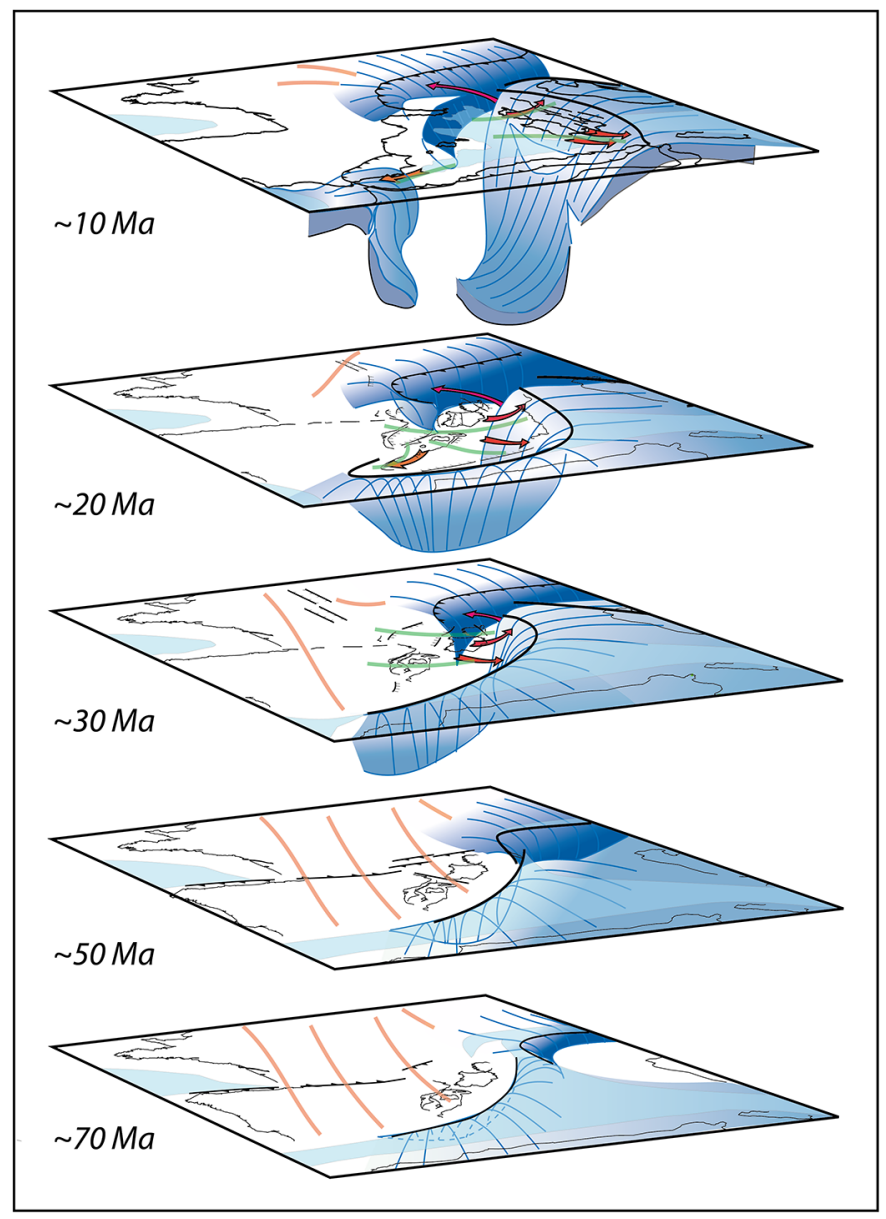

Fig. 25. Synthesis of the evolution of the Western Mediterranean slabs before, during and after slab retreat and the directions of shortening and extension. Modified from Vignaroli et al. (2008, 2009).

modifications of the convection pattern and slab behavior have been proposed. In this large-scale framework, deformation progressively localizes in the Pyrénées that then act as a new convergent plate boundary. This situation lasts until the Late Eocene with shortening distributed from the Atlas, the Alboran region, the Pyrénées and further north until the North Sea.

Between 35 and $8 \mathrm{Ma}$ (Mediterranean Tectonics), the situation changes drastically when the western Mediterranean slabs start retreating. The velocity of retreat is faster than the velocity of relative motion between Africa and Eurasia and faster than the absolute velocities of both plates. The flow of mantle resulting from slab retreat thus dominates the deformation in the Western Mediterranean. It proceeds in two main steps, the first one between 35 and 20 or $15 \mathrm{Ma}$, and the second step after $15 \mathrm{Ma}$. During the first stage, one main slab retreats southeastwards and the Liguro-Provençal Basin opens, and during the second stage, after a main slab tearing event, two slab portions retreat in opposite directions, eastward for the Calabrian Arc and westward for the Gibraltar Arc. During these periods, the mountain belts formed earlier during the Late Cretaceous and Eocene are partly dismantled. The eastern part of the Pyrénées is replaced by the Gulf of Lion rifted margin and asthenospheric flow due to slab retreat 
induces depth-dependent extension with the extraction of the lower crust and mantle from below the belt. In the Betic-Rif orogen, the internal zones (Alboran domain) are extended and metamorphic core complexes form, first with a N-S direction of extension, then E-W after $20 \mathrm{Ma}$. The Eocene nappe stack of Alpine Corsica is also reworked by extension during the rotation of the Corsica-Sardinia block and extension then migrates eastward until its present situation in the Apennines, following the retreat of the Apennines slab. At about $35 \mathrm{Ma}$, the maximum burial is recorded in HP-LT metamorphic terranes from Corsica to the Betics and the peak pressure then decreases (Tuscan archipelago) during the migration of orogenic wedges following slab retreat. This change of P-T conditions results from the change of subduction regime from compressional to extensional. The interactions of slabs at depth have consequences on the tectonic evolution of the Western Alps where the thrust front migrates westward.

From $8 \mathrm{Ma}$ onward (Late-Mediterranean Tectonics) the stress regime progressively changes again back to the pre$35 \mathrm{Ma}$ situation and the progressive recoupling between the African and Eurasian lithospheres with compression observed from the Atlas to France. This evolution coincides with the end or slowing down of slab retreat on both the Calabrian and Gibraltar subduction zones. The dragging of the slab by the mantle flow driving the absolute motion of Africa and Eurasia adds its effects on the specific deformation of the Gibraltar Arc.

During this long evolution from the Early Cretaceous to the Present, deformation in the Western Mediterranean region has been mainly controlled by the Africa-Eurasia convergence and the flow of mantle due to large-scale convection, except between 35 and $8 \mathrm{Ma}$ when slab retreat and associated mantle flow were dominant drivers and partly prevented the compressional stresses due to convergence to be transmitted from Africa to Eurasia. The observation of a compressional structures in the Central and Western Pyrénées, as well as in the Corbières until the Early Miocene (Bosch et al., 2016; Labaume et al., 2016; Teixell et al., 2018; Parizot et al., 2021), shows that some stress transmission was locally possible within the lithosphere.

Acknowledgments. This paper is a contribution of Orogen, a project funded by Total, BRGM and CNRS. It benefited from intense discussions along the course of the project with the Orogen Community.

\section{References}

Advokaat EL, van Hinsbergen DJJ, Maffione M, Langereis CG, Vissers RLM, Cherchi A, et al. 2014. Eocene rotation of Sardinia, and the paleogeography of the western Mediterranean region. Earth Planet Sci Lett 401: 183-195. https://doi.org/10.1016/j. eps1.2014.06.012.

Afilhado A, Moulin M, Aslanian D, Schnürle P, Klingelhoeffer F, Nouzé H, et al. 2015. Deep crustal structure across a young passive margin from wide-angle and reflection seismic data (The SARDINIA Experiment) - II. Sardinia's margin. Bull Soc Géol Fr 186: 331-351.

Agard P. 2021. Subduction of oceanic lithosphere in the Alps: selective and archetypal from (slow-spreading) oceans. Earth Sci Rev. https://doi.org/10.1016/j.earscirev.2021.103517.
Airaghi L, Bellahsen N, Dubacq B, Chew D, Rosenberg C, Janots E, et al. 2020. Pre-orogenic upper crustal softening by lower greenschist facies metamorphic reactions in granites of the central Pyrenees. J Metamorph Geol 38: 183-204. https://doi.org/10.1111/ jmg. 12520.

Aktug B, Nocquet JM, Cingöz A, Parsons B, Erkan Y, England P, et al. 2009. Deformation of western Turkey from a combination of permanent and campaign GPS data: Limits to block-like behavior. $J$ Geophys Res 114. https://doi.org/10.1029/2008JB006000.

Alvarez W. 2010. Protracted continental collisions argue for continental plates driven by basal traction. Earth Planet Sci Lett 296: 434-442. https://doi.org/10.1016/j.epsl.2010.1005.1030.

Alves T, Carlos M, Cunha T, Ullnaess M, Myklebust R, Monteiro J, et al. 2009. Diachronous evolution of Late Jurassic-Cretaceous continental rifting in the northeast Atlantic (west Iberian margin). Tectonics 28. https://doi.org/10.1029/2008TC002337.

Alves TM, Abreu Cunha T. 2009. A phase of transient subsidence, sediment bypass and deposition of regressive-transgressive cycles during the breakup of Iberia and Newfoundland. Earth and Planetary Science Letters 484: 168-183.

Amato A, Alessandrini B, Cimini G, Frepoli A, Selvaggi G. 1993. Active and remanant subducted slabs beneath Italy: evidence from seismic tomography and seismicity. Annali di Geofisica XXXVI: 201-214.

Andrieu S, Saspiturry N, Lartigau M, Issautier B, Angrand P, Lasseur E. 2021. Large-scale vertical movements in Cenomanian to Santonian carbonate platform in Iberia: indicators of a Coniacian pre-orogenic compressive stress. BSGF - Earth Sciences Bulletin 192: 19.

Angiboust S, Agard P, Jolivet L, Beyssac O. 2009. The Zermatt-Saas ophiolite: the largest (60-km wide) and deepest (c. $70-80 \mathrm{~km})$ continuous slice of oceanic lithosphere detached from a subduction zone? Terra Nova 21: 171-180. https://doi.org/10.1111/ j.1365-3121.2009.00870.x.

Angiboust S, Glodny J. 2020. Exhumation of eclogitic ophiolitic nappes in the W. Alps: New age data and implications for crustal wedge dynamics. Lithos 356-357: 105374. https://doi.org/ 10.101016/j.lithos.102020.105374.

Angrand P, Ford M, Watts AB. 2018. Lateral variations in foreland flexure of a rifted continental margin: The Aquitaine Basin (SW France). Tectonics 37: 430-449. https://doi.org/410.1002/ 2017TC004670.

Angrand P, Mouthereau F, Masini E, Asti R. 2020. A reconstruction of Iberia accounting for W-Tethys/N-Atlantic kinematics since the late Permian-Triassic. Solid Earth, European Geosciences Union. https://doi.org/10.5194/se-2020-5124.

Armijo R, Meyer B, Hubert A, Barka A. 1999. Westward propagation of the north Anatolian into the northern Aegean: timing and kinematics. Geology 27: 267-270.

Arthaud F, Matte P. 1977. Determination de la position initiale de la Corse et de la Sardaigne à la fin de l'orogénèse hercynienne grâce aux marqueurs géologiques, magmatiques et paléomagnétiques. Bulletin de la Société géologique de France 19: 833-840.

Arthaud F, Séguret M. 1981. Les structures pyrénéennes du Languedoc et du Golfe du Lion (Sud de la France). Bull Soc Géol Fr XXIII: 51-63.

Aubouin J. 1959. Contribution à l'étude de la Grèce septentrionale; les confins de l'Epire et de la Thessalie. Ann Géol Pays Hellén 10: $1-483$.

Aubouin J, Brunn JH, Celet P, Dercourt J, Godfriaux I, Mercier J. 1962. Esquisse de la géologie de la Grèce. Bull Soc Géol Fr 2: 583-610.

Augier R, Agard P, Jolivet L, Monié P, Robin C, Booth-Rea G. 2005a. Exhumation, doming and slab retreat in the Betic Cordillera (SE Spain): in situ 40Ar/39Ar ages and $\mathrm{P}-\mathrm{T}-\mathrm{d}-\mathrm{t}$ paths for the 
Nevado-Filabride complex. J Metam Geol 23: 357-381. https://doi. org/10.1111/j.1525-1314.2005.00581.x.

Augier R, Booth-Rea G, Agard P, Martinez-Martinez JM, Jolivet L, Azañon JM. 2005b. Exhumation constraints for the lower NevadoFilabride Complex (Betic Cordillera, SE Spain): a Raman thermometry and Tweequ multiequilibrium thermobarometry approach. Bull Soc Géol Fr 176: 403-416. https://doi.org/10.2113/ 2176.2115.2403.

Augier R, Jolivet L, Do Couto D, Negro F. 2013. From ductile to brittle, late- to post-orogenic evolution of the Betic Cordillera: Structural insights from the northeastern Internal zones. Bull Soc Géol Fr 184: 405-425.

Babault J, Teixell A, Arboleya ML, Charroud M. 2008. A Late Cenozoic age for long-wavelength surface uplift of the Atlas Mountains of Morocco. Terra Nova 20: 102-107. https://doi.org/ 10.1111/j.1365-3121.2008.00794.x.

Babault J, Van Den Driessche J, Bonnet S, Castelltort S, Crave A. 2005. Origin of the highly elevated Pyrenean peneplain. Tectonics. https://doi.org/10.1029/2004TC001697.

Bache F, Olivet JL, Gorini C, Aslanian D, Labails C, Rabineau M. 2010. Evolution of rifted continental margins: The case of the Gulf of Lions (Western Mediterranean Basin). Earth Planet Sci Lett 292: 345-356.

Baize S, Cushing EM, Lemeille F, Jomard H. 2013. Updated seismotectonic zoning scheme of Metropolitan France, with reference to geologic and seismotectonic data. Bull Soc Géol Fr 184: 225-259.

Barnett-Moore N, Hosseinpour M, Maus S. 2016. Assessing discrepancies between previous plate kinematic models of Mesozoic Iberia and their constraints. Tectonics 35: 1843-1862. https://doi.org/10.1002/2015TC004019.

Barrier E, Vrielynck B. 2008. Paleotectonic Maps of the Middle East: Atlas of 14 Maps. Paris: Commission de la Carte Géologique du Monde.

Barruol G, Granet M. 2002. A Tertiary asthenospheric flow beneath the southern French Massif Central indicated by upper mantle seismic anisotropy and related to the west Mediterranean extension. Earth Planet Sci Lett 202: 31-47.

Beaudoin A, Augier R, Jolivet L, Jourdon A, Raimbourg H, Scaillet S, et al. 2017. Deformation behavior of continental crust during subduction and exhumation: Strain distribution over the Tenda massif (Alpine Corsica, France). Tectonophysics 705: 12-32. https://doi.org/10.1016/j.tecto.2017.1003.1023.

Beaudoin A, Scaillet S, Mora N, Jolivet L, Augier R. 2020. In situ and step-heating $40 \mathrm{Ar} / 39 \mathrm{Ar}$ dating of white mica in low-temperature shear zones (Tenda massif, Alpine Corsica, France). Tectonics 39: e2020TC006246. https://doi.org/10.1029/2020TC006246.

Beaumont C, Muñoz JA, Hamilton J, Fullsack P. 2000. Factors controlling the Alpine evolution of the central Pyrenees inferred from a comparison of observations and geodynamical models. $J$ Geophys Res 105: 8121-8145. https://doi.org/10.1029/ 1999JB900390.

Becker TW, Faccenna C. 2011. Mantle conveyor beneath the Tethyan collisional belt. Earth Planet Sci Lett 310: 453-461. https://doi.org/ 10.1016/j.eps1.2011.1008.1021.

Bellahsen N, Bayet L, Denele Y, Waldner M, Airaghi L, Rosenberg C, et al. 2019. Shortening of the axial zone, pyrenees: Shortening sequence, upper crustal mylonites and crustal strength. Tectonophysics 766: 433-452. https://doi.org/10.1016/j.tecto.2019.1006.1002.

Bellahsen N, Faccenna C, Funiciello F, Daniel JM, Jolivet L. 2003. Why did Arabia separate from Africa, insights from 3-D laboratory experiments. Earth Planet Sci Lett 216: 365-381.
Bellahsen N, Mouthereau F, Boutoux A, Bellanger M, Lacombe O, Jolivet L, et al. 2014. Collision kinematics in the western external Alps. Tectonics 33: 1055-1088. https://doi.org/10.1002/ 2013 TC003453.

Bellanger M, Augier R, Bellahsen N, Jolivet L, Monié P, Baudin T, et al. 2015. Shortening of the European Dauphinois margin (Oisans Massif, Western Alps): New insights from RSCM maximum temperature estimates and $40 \mathrm{Ar} / 39 \mathrm{Ar}$ in situ dating. Journal of Geodynamics 83: 37-64. https://doi.org/10.1016/j. jog.2014.1009.1004.

Bellanger M, Bellahsen N, Jolivet L, Baudin T, Augier R, Boutoux A. 2014. Basement shear zones development and shortening kinematics in the Ecrins Massif, Western Alps. Tectonics 33. https://doi.org/10.1002/2013TC003294.

Benaouali-Mebarek N, Frizon de Lamotte D, Roca E, Bracene R, Faure JL, Sassi W, et al. 2006. Post-Cretaceous kinematics of the Atlas and Tell systems in central Algeria: Early foreland folding and subduction-related deformation. C R Geosci 338: 115-125.

Bergerat F. 1987. Stress field in the European platform at the time of Africa-Eurasia collision. Tectonics 6: 99-132.

Bernard T, Sinclair HD, Gailleton B, Mudd SM, Ford M. 2019. Lithological control on the post-orogenic topography and erosion history of the Pyrenees. Earth and Planetary Science Letters 518: 53-66. https://doi.org/10.1016/j.epsl.2019.1004.1034.

Bernard T, Sinclair HD, Naylor M, Christophoul F, Ford M. 2020. Post-orogenic sediment drape in the Northern Pyrenees explained using a b o x model. Basin Res. https://doi.org/10.1111/bre.12457.

Bertrand M. 1887. Ilot triasique du Beausset (Var). Analogie avec le bassin houiller franco-belge et avec les Alpes de Glaris. Bull Geol Soc Fr 15: 667-702.

Bessière E. 2019. Évolution géodynamique des zones internes des Cordillères Bétique (Andalousie, Espagne) : apports d'une étude pluridisciplinaire du complexe Alpujarride, OSUC. Orléans: Université d'Orléans, p. 316.

Bessière E, Jolivet L, Augier R, Scaillet S, Précigout J, Azañon JM, et al. 2021. Lateral variations of pressure-temperature evolution in non-cylindrical orogens and 3-D subduction dynamics, the BeticsRif example. BSGF - Earth Sciences Bulletin 192: 8. https://doi. org/10.1051/bsgf/2021007.

Bessis F. 1986. Some remarks on the study of subsidence of sedimentary basins. Applications to the Gulf of Lions margin (Western Mediterranean). Marine and Petroleum Geology 3: 3763.

Bestani L, Espurt N, Lamarche J, Floquet M, Philip J, Bellier O, et al. 2015. Structural style and evolution of the Pyrenean-Provence thrust belt, SE France. Bull Soc Géol Fr 186(4-5): 223-241.

Bianco C, Brogi A, Caggianelli A, Giorgetti G, Liotta D, Meccheri M. 2015. HP-LT metamorphism in Elba Island: Implications for the geodynamic evolution of the inner Northern Apennines (Italy). Journal of Geodynamics 91: 13-25. https://doi.org/10.1016/j. jog.2015.1008.1001.

Bianco C, Godard G, Halton A, Brogi A, Liotta D, Caggianelli A. 2019. The lawsonite-glaucophane blueschists of Elba Island (Italy). Lithos 348-349: 105198. https://doi.org/10.101016/j.lith os.102019.105198.

Bilotte M. 1985. Le Crétacé supérieur des plates-formes estpyrénéennes. Strata, série 2 5: 1-438.

Billi A, Faccenna C, Bellier O, Minelli L, Neri G, Piromallo C, et al. 2011. Recent tectonic reorganization of the Nubia-Eurasia convergent boundary heading for the closure of the western Mediterranean. Bull Soc Géol Fr 182: 279-303.

Bird P. 1979. Continental delamination and the Colorado plateau. $J$ Geophys Res 84: 7561-7571. 
Bird P. 1991. Lateral extrusion of lower crust from under hight topography in the isostatic limit. J Geophys Res 96: 10275-10286.

Biteau JJ, Le Marrec A, Le Vot M, Masset JM. 2006. The Aquitaine Basin. Petroleum Geoscience 12: 247-273.

Blake MC, Bonneau M, Geyssant J, Kienast JR, Lepvrier C, Maluski $\mathrm{H}$, et al. 1981. A geological reconnaissance of the Cyclacic blueschist belt, Greece. Bull Geol Soc Am 92: 247-254. https://doi. org/10.1130/0016-7606(1981)1192<1247:AGROTC > 1132.1130. $\mathrm{CO} ; 1132$.

Bonneau M, Kienast JR. 1982. Subduction, collision et schistes bleus: exemple de l'Egée, Grèce. Bull Soc Géol Fr 7: 785-791.

Booth-Rea G, Ranero CR, Martinez-Martinez JM, Grevemeyer I. 2007. Crustal types and Tertiary tectonic evolution of the Alborán sea, western Mediterranean. Geochem Geophys Geosyst 8: Q10005. https://doi.org/10010.11029/12007GC001639.

Bosch GV, Teixell A, Jolivet M, Labaume P, Stockli D, Domènech M, et al. 2016. Timing of Eocene-Miocene thrust activity in the Western Axial Zone and Chaînons Béarnais (west-central Pyrenees) revealed by multi-method thermochronology. $C R$ Geosci 348: 246-256.

Bouillin JP, Durand-Delga M, Olivier P. 1986. Betic, Rifian and Tyrrhenian arcs: distinctive features, genesis and development stage. In: Wezel FC, ed. The origin of Arcs. New York: Elsevier, pp. 281-304.

Bourgeois O, Ford M, Diraison M, Le Carlier de Veslud C, Gerbault M, Pik R, et al. 2007. Separation of rifting and lithospheric folding signatures in the NW-Alpine foreland. Int J Earth Sci (Geol Rundsch) 96: 1003-1031. https://doi.org/10.1007/s00531-0000700202-00532.

Bousquet R, Goffé B, Henry P, Le Pichon X, Chopin C. 1997. Kinematic, thermal and petrological model of the Central Alps: Lepontine metamorphism in the Upper Crust and eclogitisation of the lower crust. Tectonophysics 273: 105-128.

Bousquet R, Oberhänsli R, Goffé B, Wiederkehr M, Koller F, Schmid SM, et al. 2008. Metamorphism of metasediments at the scale of an orogen: a key to the Tertiary geodynamic evolution of the Alps. In: Siegiesmund S, Fügenschuh B, Froitzheim N, eds. Tectonic Aspects of the Alpine-Dinaride-Carpathian System. London: The Geological Society of London, pp. 393-411. https://doi.org/ 10.1144/SP1298.11180305-8719/1108/\$1115.1100.

BRGM, Elf, Esso, SNPA. 1974. Géologie du bassin d'aquitaine. BRGM Editions.

Brogi A, Lazzarotto A, Liotta D, Ranalli G. 2003. Extensional shear zones as imaged by reflection seismic lines: the Larderello geothermal field (central Italy). Tectonophysics 363: 127-139.

Bruguier O, Bosch D, Caby R, Vitale-Brovarone A, Fernandez L, Hammor D, et al. 2017. Age of UHP metamorphism in the Western Mediterranean: Insight from rutile and minute zircon inclusions in a diamond-bearing garnet megacryst (Edough Massif, NE Algeria). Earth Planet Sci Lett 474: 215-225. https://doi.org/10.1016/j. eps1.2017.1006.1043.

Buontempo L, Bokelmann GHR, Barruol G, Morales J. 2008. Seismic anisotropy beneath southern Iberia from SKS splitting. Earth Planet Sci Lett 273: 237-250. https://doi.org/10.1016/j. eps1.2008.1006.1024.

Burke K, Steinberger B, Torsvik TH, Smethurst MA. 2008. Plume Generation Zones at the margins of Large Low Shear Velocity Provinces on the core-mantle boundary. Earth and Planetary Science Letters 265: 49-60. https://doi.org/10.1016/j.epsl.2007.1009.1042.

Burke K, Torsvik TH. 2004. Derivation of Large Igneous Provinces of the past 200 million years from long-term heterogeneities in the deep mantle. Earth Planet Sci Lett 227: 531-538.
Burov EB. 2011. Rheology and strength of the lithosphere. Marine and Petroleum Geology 28: 1402-1443. https://doi.org/10.1016/j. marpetgeo.2011.1405.1008.

Burov E, Gerya T. 2014. Asymmetric three-dimensional topography over mantle plumes. Nature 513: 85-89. https://doi.org/10.1038/ nature 13703 .

Burrus J. 1989. Review of geodynamics models for extensional basins; the paradox of stretching in the Gulf of Lions (Northwest Mediterranean). Bull Soc Géol Fr V: 377-393.

Calais E, Nocquet JM, Jouanne F, Tardy M. 2002. Current strain regime in the Western Alps from continuous Global Positioning System measurements, 1996-2001. Geology 30: 651-654.

Calvet M, Gunnell Y, Laumonier B. 2021. Denudation history and palaeogeography of the Pyrenees and their peripheral basins: an $84-$ million-year geomorphological perspective. Earth-Science Reviews 215(2021): 103436. https://doi.org/10.1016/j.ear scirev.2020.103436.

Canérot J. 2016. The Iberian Plate: myth or reality? Boletín Geológico y Minero 127: 563-574.

Canva A, Thinon I, Peyrefitte A, Couëffé R, Maillard A, Jolivet L, et al. 2020. The Catalan magnetic anomaly: significance on crustal structure of the Gulf of Lion passive margin and link to the Catalan Transfer Zone. Marine and Petroleum Geology 113. https://doi.org/ 10.1016/j.marpetgeo.2019.104174.

Capella W, Spakman W, Chertova MV, Krijgsman W. 2019. Mantle resistance against Gibraltar slab dragging as a key cause of the Messinian Salinity Crisis. Terra Nova: 1-10. https://doi.org/ 10.1111/ter.12442.

Capitanio FA. 2014. The dynamics of extrusion tectonics: Insights from numerical modeling. Tectonics 33: 2361-2381. https://doi. org/10.1002/2014TC003688.

Capitanio FA, Replumaz A, Riel N. 2015. Reconciling subduction dynamics during Tethys closure with large-scale Asian tectonics: Insights from numerical modeling. Geochem Geophys Geosyst 16: 962-982. https://doi.org/10.1002/2014GC005660.

Carminati E, Wortel MJR, Meijer PT, Sabadini R. 1998a. The twostage opening of the western-central mediterranean basins: a forward modeling test to a new evolutionary model. Earth Planet Sci Lett 160: 667-679.

Carminati E, Wortel MJR, Spakman W, Sabadini R. 1998b. The role of slab detachment processes in the opening of the western-central Mediterranean basins: some geological and geophysical evidence. Earth Planet Sci Lett 160: 651-665.

Chalouan A, Michard A, El Kadiri K, Negro F, Frizon de Lamotte D, Soto JI, et al. 2008. The Rif Belt. In: Michard A, et al., eds. Continental Evolution: The Geology of Morocco, Lecture Notes 203 in Earth Sciences. Berlin, Heidelberg: Springer-Verlag Berlin Heidelberg.

Chamot-Rooke N, Gaulier JM, Jestin F. 1999. Constraints on Moho depth and crustal thickness in the Liguro-Provençal basin from a 3D gravity inversion: geodynamic implications. In: Durand B, Jolivet L, Horvàth F, Séranne M, eds. Geol Soc Special Publication. London: Geological Society, pp. 37-62.

Chelalou R, Nalpas T, Bousquet R, Prevost M, Lahfid A, Poujol M, et al. 2016. New sedimentological, structural and paleo-thermicity data in the Boucheville Basin (eastern North Pyrenean Zone, France). $C R$ Geosci 348: 312-321. https://doi.org/10.1016/j. crte.2015.1011.1008.

Chertova MV, Spakman W, Geenen T, van den Berg AP, van Hinsbergen DJJ. 2014. Underpinning tectonic reconstructions of the western Mediterranean region with dynamic slab evolution from 3-D numerical modeling. J Geophys Res Solid Earth 119: 5876-5902. https://doi.org/10.1002/2014JB011150. 
Chevrot S, Sylvander M, Diaz J, Martin R, Mouthereau F, Manatschal $\mathrm{G}$, et al. 2018. The non-cylindrical crustal architecture of the Pyrenees. Scientific Reports 8: 9591. https://doi.org/10.1038/ s41598-41018-27889-x.

Chevrot S, Villasenor A, Sylvander M, the PYROPE Working Group. 2014. High resolution imaging of the Pyrenees and Massif Central from the data of the PYROPE and IBERARRAY portable array deployments. J Geophys Res 19: 6399-6420. https://doi.org/ 10.1002/2014JB010953,012014.

Chopin C. 1984. Coesite and pure pyrope in high-grade blueschists of the western Alps: A first record and some consequences. Contrib Mineral Petrol 86: 107-118.

Choukroune P. 1989. The ECORS Pyrenean deep seismic profile reflection data and the overall structure of an orogenic belt. Tectonics 8: 23-39.

Choukroune P, Mattauer M. 1978. Tectonique des plaques et Pyrenées : sur le fonctionnement de la faille transformante nord-pyrénéenne; comparaison avec les modèles actuels. Bull Soc Géol Fr 7: 689_ 700.

Choukroune P, Roure F, Pinet B, ECORS PYRENEES TEAM. 1990. Main results of the ECORS Pyrenees profile. Tectonophysics 173: 411-423.

Christophoul F, Soula JC, Brusset S, Elibana B, Roddaz M, Bessiere $\mathrm{G}$, et al. 2003. Time, place and mode of propagation of foreland basin systems as recorded by the sedimentary fill: examples of the Late Cretaceous and Eocene retro-foreland basins of the northeastern Pyrenees. Geological Society, London, Special Publications 208: 229-252.

Clerc C, Boulvais P, Lagabrielle Y, de Saint Blanquat M. 2014. Ophicalcites from the northern Pyrenean belt: a field, petrographic and stable isotope study. Int J Earth Sci (Geol Rundsch) 103: 141163. https://doi.org/10.1007/s00531-00013-00927-z.

Clerc C, Jolivet L, Ringenbach JC. 2015a. Ductile extension shear zones on the lower crust of a passive margin. Earth Planet Sci Lett 431: 1-7. https://doi.org/10.1016/j.eps1.2015.1008.1038.

Clerc C, Lagabrielle Y. 2014. Thermal control on the modes of crustal thinning leading to mantle exhumation: Insights from the Cretaceous Pyrenean hot paleomargins. Tectonics 33: 13401359. https://doi.org/10.1002/2013TC003471.

Clerc C, Lagabrielle Y, Labaume P, Ringenbach JC, Vauchez A, Nalpas T, et al. 2016. Basement-Cover decoupling and progressive exhumation of metamorphic sediments at hot rifted margin. Insights from the Northeastern Pyrenean analog. Tectonophysics 686: 82-97. https://doi.org/10.1016/j.tecto.2016.1007.1022.

Clerc C, Lagabrielle Y, Neumaier M, Reynaud JY, de Saint Blanquat M. 2012. Exhumation of subcontinental mantle rocks: evidence from ultramafic-bearing clastic deposits nearby the Lherz peridotite body, French Pyrenees. Bull Soc Géol Fr 183: 443-459.

Clerc C, Lahfid A, Monié P, Lagabrielle Y, Chopin C, Poujol M, et al. 2015b. High-temperature metamorphism during extreme thinning of the continental crust: a reappraisal of the North Pyrenean passive paleomargin. Solid Earth 6: 643-668. https://doi.org/10.5194/se5196-5643-2015.

Clerc C, Ringenbach JC, Jolivet L, Ballard JF. 2017. Rifted margins: ductile deformation, boudinage, continentward-dipping normal faults and the role of the weak lower crust. Gondwana Research 53: 20-40. https://doi.org/10.1016/j.gr.2017.1004.1030.

Cloetingh S, Thybo H, Faccenna C. 2009. TOPO-EUROPE: Studying continental topography and Deep Earth-Surface processes in 4D. Tectonophysics 474: 4-32. https://doi.org/10.1016/j. tecto.2009.1004.1015.

Cloetingh S, van Wees JD, Ziegler PA, Lenkey L, Beekman F, Tesauro $\mathrm{M}$, et al. 2010. Lithosphere tectonics and thermo-mechanical properties: An integrated modelling approach for Enhanced Geothermal Systems exploration in Europe. Earth-Science Reviews 102: 159-206. https://doi.org/10.1016/j.earscirev.2010.1005.1003.

Cochelin B, Chardon D, Denèle Y, Gumiaux C, Le Bayon B. 2017. Vertical strain partitioning in hot Variscan crust: Syn-convergence escape of the Pyrenees in the Iberian-Armorican syntax. BSGF Earth Sciences Bulletin 188: 39. https://doi.org/10.1051/bsgf/ 2017206.

Collettini C, Barchi MR. 2002. A low-angle normal fault in the Umbria region (Central Italy): a mechanical model for the related microseismicity. Tectonophysics 359: 97-115.

Collettini C, Barchi MR. 2004. A comparison of structural data and seismic images for low-angle normal faults in the Northern Apennines (Central Italy): constraints on activity. In: Alsop GI, Holdsworth RE, McCaffrey KJW, Hands M, eds. Flow processes in faults and shear zones. London: Geological Society, pp. 95-112.

Collettini C, Holdsworth RE. 2004. Fault zone weakening and character of slip along low-angle normal faults: insights from the Zuccale fault, Elba, Italy. J Geol Soc Lond 161: 1039-1051.

Coltice N, Husson L, Faccenna C, Arnould M. 2019. What drives tectonic plates? Sciences Advances 5: eaax4295.

Comas MC, Garcia-Duenas V, Jurado MJ. 1992. Neogene tectonic evolution of the Alboran Sea from MCS data. Geol Mar Lett 12: $157-164$

Comas MC, Platt JP, Soto JI, Watts AB. 1999. The origin and tectonic history of the Alboran basin: insights from Leg 161 results. In: Zahn R, Comas MC, Klaus A, eds. Proc. ODP, Sci. Results. TX (Ocean Drilling Program), College Station, pp. 555-582.

Conrad CP, Lithgow-Bertelloni C. 2002. How mantle slabs drive plate tectonics. Science 298.

Cornet FH, Burlet D. 1992. Stress field determination in France by hydraulic test in boreholes. J Geophys Res 97: 11829-11849.

Crespo-Blanc A. 1995. Interference pattern of extensional fault systems: a case study of the Miocene rifting of the Alboran basement (North of Sierra Nevada, Betic Chain). J Struct Geol 17: 1559-1569.

Crespo-Blanc A, Orozco M, Garcia-Duenas V. 1994. Extension versus compression during the Miocene tectonic evolution of the Betic chain. Late folding of normal fault system. Tectonics 13: 7888.

Crespo-Blanc A, Comas M, Balanyá JC. 2016. Clues for a Tortonian reconstruction of the Gibraltar Arc: Structural pattern, deformation diachronism and block rotations. Tectonophysics 683: 308-324. https://doi.org/10.1016/j.tecto.2016.1005.1045.

Curry ME, van der Beek P, Huismans RS, Wolf SG, Muñoz JP. 2019. Evolving paleotopography and lithospheric flexure of the Pyrenean Orogen from 3D flexural modeling and basin analysis. Earth and Planetary Science Letters 515: 26-37. https://doi.org/10.1016/j. eps1.2019.1003.1009.

d'Acremont E, Lafosse M, Rabaute A, Teurquety G, Do Couto D, Ercilla G, et al. 2020. Polyphase tectonic evolution of fore-arc basin related to STEP fault as revealed by seismic reflection data from the Alboran Sea (W-Mediterranean). Tectonics 39: e2019TC005885. https://doi.org/10.1029/2019TC005885.

D'Agostino N, Chamot-Rooke N, Funiciello R, Jolivet L, Speranza F. 1998. The role of pre-existing thrust faults and topography on the styles of extension in the Gran Sasso range (Central Italy). Tectonophysics 292: 229-254.

Daril N. 2018. Cartographie de l'exhumation syn-à-post orogénique de la chaîne Pyrénéenne par modélisation 3D de données thermochonologiques. Mémoire de Master 2. Paris: Polytech Sorbonne, Sorbonne Université. 
Daudet M, Mouthereau F, Brichau S, Crespo-Blanc A, Gautheron C, Angrand P. 2020. Tectono-stratigraphic and thermal evolution of the western Betic flyschs: implications for the geodynamics of South Iberian margin and Alboran Domain. Tectonics 39: e2020TC006093. https://doi.org/10.1029/2020TC006093.

de Larouzière FD, Bolze $\mathrm{J}$, Bordet $\mathrm{P}$, Hernadez $\mathrm{J}$, Montenant $\mathrm{C}$, et al. 1988. The Betic segment of the lithospheric Trans-Alboran shear zone during the Late Miocene. Tectonophysics 152: 41-52.

de Lis Mancilla F, Heit B, Morales J, Yuan X, Stich D, MolinaAguilera A, et al. 2018. A STEP fault in Central Betics, associated with lateral lithospheric tearing at the northern edge of the Gibraltar arc subduction system. Earth and Planetary Science Letters 486: 32-40. https://doi.org/10.1016/j.epsl.2018.1001.1008.

De Voogd B, Nicolich R, Olivet JL, Fanucci F, Burrus J, Mauffret A, et al. 1991. First deep seismic reflection transect from the Gulf of Lions to Sardinia (ECORS-CROP profiles in Western Mediterranean). In: Meissner R, Brown L, Durbaum HJ, Fuchs K, Seifert F, eds. Continental lithosphere: deep seismic reflections. Washington D.C.: American Geophysical Union, pp. 265-274.

Delacou B, Sue C, Champagnac JD, Burkhard M. 2004. Present-day geodynamics in the bend of the western and central Alps as constrained by earthquake analysis. Geophys $J$ Int 158: 753-774.

Denèle Y, Olivier P, Gleizes G. 2008. Progressive deformation of a zone of magma transfer in a transpressional regime: The Variscan Mérens shear zone (Pyrenees, France). Journal of Structural Geology 30: 1138-1149. https://doi.org/10.1016/j. jsg.2008.1105.1006.

Denèle Y, Olivier P, Gleizes G, Barbey P. 2007. The Hospitalet gneiss dome (Pyrenees) revisited: lateral flow during Variscan transpression in the middle crust. Terra Nova 19: 445-453. https://doi. org/10.1111/j.1365-3121.2007.00770.x.

Denèle Y, Olivier P, Gleizes G, Barbey P. 2009. Decoupling between the middle and upper crust during transpression-related lateral flow: Variscan evolution of the Aston gneiss dome (Pyrenees, France). Tectonophysics 477: 244-261. https://doi.org/10.1016/j. tecto.2009.1004.1033.

Dercourt J, Ricou LE, Vrielinck B. 1993. Atlas Tethys Palaeo environmental Maps. Paris: Gauthier-Villars.

Dercourt J, Zonenshain LP, Ricou LE, Kuzmin VG, Le Pichon X, Knipper AL, et al. 1986. Geological evolution of the Tethys belt from the Atlantic to the Pamir since the Lias. Tectonophysics 123: 241-315.

Deverchère J, Yelles K, Calais E. 2003. Active deformation along the Algerian Margin (MARADJA cruise): framework of the May 21 2003 Mw-6.8 Boumerdes earthquke. EOS Trans AGU 84: S42E0216.

Dewey JF. 1980. Episodicity, sequence, and style at convergent plate boundaries. In: Stangway DW, ed. The continental crust and its mineral deposits. Geol Assoc Canada Spec Pap 20: 553-573.

Dewey JF, Helman ML, Turco E, Hutton DHW, Knott SD. 1989. Kinematics of the Western Mediterranean. In: Coward MP, Dietrich D, Park RG, eds. Alpine Tectonics. Geol Soc Spec Publ Lond 45: 265-283.

Dèzes P, Schmid SM, Ziegler PA. 2004. Evolution of the European Cenozoic Rift System: interaction of the Alpine and Pyrenean orogens with their foreland lithosphere. Tectonophysics 389: 1-33.

Diaz J, Gallart J, Carbonell R. 2016. Moho topography beneath the Iberian-Western Mediterranean region mapped from controlledsource and natural seismicity surveys. Tectonophysics 692: 74-85.

Diaz J, Vergés J, Chevrot S, Antonio-Vigil A, Ruiza M, Sylvander M, et al. 2018. Mapping the crustal structure beneath the eastern Pyrenees. Tectonophysics 744: 296-309. https://doi.org/10.1016/j. tecto.2018.1007.1011.
Dielforder A, Frasca G, Brune S, Ford M. 2019. Formation of the Iberian-European Convergent Plate Boundary Fault and Its Effect on Intraplate Deformation in Central Europe. Geochem Geophys Geosyst 20: 2395-2417. https://doi.org/10.1029/2018GC007840.

Do Couto D, Gorini C, Jolivet L, Lebret N, Augier R, Gumiaux C, et al. 2016. Tectonic and stratigraphic evolution of the Western Alboran Sea Basin in the last 25 Myrs. Tectonophysics. https://doi. org/10.1016/j.tecto.2016.1003.1020.

Do Couto D, Gumiaux C, Augier R, Lebret N, Folcher N, Jouannic G, et al. 2014. Tectonic inversion of an asymmetric graben: Insights from a combined field and gravity survey in the Sorbas basin. Tectonics 33. https://doi.org/10.1002/2013TC003458.

Doglioni C, Agostini S, Crespi M, Innocenti F, Manetti P, Riguzzi F, et al. 2002. On the extension in western Anatolia and the Aegean sea. Journal of the Virtual Explorer 7: 167-181.

Doubrovine P, Steinberger B, Torsvik TH. 2012. Absolute plate motions in a reference frame defined by moving hotspots in the Pacific, Atlantic and Indian oceans. J Geoph Res 117: B09101. https://doi.org/10.01029/02011JB009072.

Driussi O, Briais A, Maillard A. 2015. Evidence for transform motion along the South Balearic margin and Implications for the kinematics of opening of the Algerian basin. Bull Soc Géol Fr 186: 353-370.

Duchêne S, Blichert-Toft J, Luais B, Telouk P, Lardeaux JM, Albarède F. 1997a. The Lu-Hf dating of garnets and the ages of the alpine high-pressure metamorphism. Nature 387: 586.

Duchêne S, Lardeaux JM, Albarède F. 1997b. Exhumation of eclogites: insights from depth-time analysis. Tectonophysics 280: 125-140.

Ducoux M, Jolivet L, Cagnard F, Gumiaux C, Baudin T, Masini E, et al. 2019. The Nappe des Marbres unit of the Basque Cantabrian basin: the tectono-thermal evolution of a fossil hyperextended rift basin. Tectonics 38. https://doi.org/10.1029/2018TC005348.

Ducoux M, Jolivet L, Masini E, Augier R, Lahfid A, Bernet M, et al. 2021a. Distribution and intensity of High-Temperature LowPressure metamorphism across the Pyrenean-Cantabrian belt: unravelling the thermal record of hyperextension rifting. $B S G F$ Earth Sciences Bulletin 200063. https://doi.org/10.1051/bsgf/ 2021029.

Ducoux M, Jolivet L, Cagnard F, Baudin T. 2021b. Basement-cover decoupling during the inversion of a hyperextended basin: Insights from the Eastern Pyrenees. Tectonics 40: e2020TC006512. https:// doi.org/006510.001029/002020TC006512.

Elsasser WM. 1968. The mechanics of continental drift. Proceedings of the American Philosophical Society 112: 344-353.

England P, Houseman G. 1989. Extension during continental convergence with application to the Tibetan plateau. $J$ Geophys Res 94: 17561-17579.

Espurt N, Angrand P, Teixell A, Labaume P, Ford M, de Saint Blanquat M, Chevrot S. 2019. Crustal-scale balanced cross-section and restorations of the Central Pyrenean belt (Nestes-Cinca transect): Highlighting the structural control of Variscan belt and Permian-Mesozoic rift systems on mountain building. Tectonophysics 764(2019): 25-45. https://doi.org/10.1016/j. tecto.2019.1004.1026.

Estrada F, Galindo-Zaldıvar J, Vazquez JT, Ercilla G, D'Acremont E, Alonso B, et al. 2017. Tectonic indentation in the central Alboran Sea (westernmost Mediterranean). Terra Nova 30: 24-33. https:// doi.org/10.1111/ter.12304.

Etheve N, Mohn G, Frizon de Lamotte D, Roca E, Tugend J, GómezRomeu J. 2018. Extreme Mesozoic crustal thinning in the eastern Iberia margin: The example of the Columbrets Basin (Valencia Trough). Tectonics 37. https://doi.org/10.1002/2017TC004613. 
Evans D, Graham C, Armour A, Bathurst P. 2003. The Millennium Atlas: petroleum geology of the central and northern North Sea. London: The Geological Society of London.

Faccenna C, Becker TW, Auer L, Billi A, Boschi L, Brun JP, et al. 2014. Mantle dynamics in the Mediterranean. Reviews of Geophysics 52: 283-332. https://doi.org/10.1002/2013RG000444.

Faccenna C, Becker TW, Conrad CP, Husson L. 2013a. Mountain building and mantle dynamics. Tectonics 32: 80-93. https://doi.org/ 10.1029/2012TC003176.

Faccenna C, Becker TW, Jolivet L, Keskin M. 2013b. Mantle convection in the Middle East: Reconciling Afar upwelling, Arabia indentation and Aegean trench rollback. Earth Planet Sci Lett 375: 254-269. https://doi.org/10.1016/j.eps1.2013.1005.1043.

Faccenna C, Becker TW, Lucente FP, Jolivet L, Rossetti F. 2001a. History of subduction and back-arc extension in the Central Mediterranean. Geophys J Int 145: 809-820.

Faccenna C, Bellier O, Martinod J, Piromallo C, Regard V. 2006. Slab detachment beneath eastern Anatolia: A possible cause for the formation of the North Anatolian fault. Earth and Planetary Science Letters 242: 85-97.

Faccenna C, Civetta L, D'Antonio M, Funiciello F, Margheriti L, Piromallo C. 2005. Constraints on mantle circulation around the deforming Calabrian slab. Geophys Res Lett 32: L06311. https:// doi.org/10.01029/02004GL021874.

Faccenna C, Funiciello F, Giardini D, Lucente P. 2001b. Episodic back-arc extension during restricted mantle convection in the Central Mediterranean. Earth Planet Sci Lett 187: 105-116.

Faccenna C, Jolivet L, Piromallo C, Morelli A. 2003. Subduction and the depth of convection in the Mediterranean mantle. $J$ Geophys Res 108: 2099. https://doi.org/10.1029/2001JB001690.

Faccenna C, Piromallo C, Crespo-Blanc A, Jolivet L, Rossetti F. 2004. Lateral slab deformation and the origin of the Western Mediterranean arcs. Tectonics 23. https://doi.org/10.1029/ 2002 TC001488.

Fillon C, Mouthereau F, Calassou S, Pik R, Bellahsen R, Gautheron C, et al. 2021. Post-orogenic exhumation in the western Pyrenees: evidence for extension driven by pre-orogenic inheritance. Journal of the Geological Society 178: jsg2020-2079. https://doi.org/ 10.1144/jgs2020-1079.

Fitzgerald PG, Muñoz JA, Coney PJ, Baldwin SL. 1999. Asymmetric exhumation across the Pyrenean orogen: Implications for the tectonic evolution of a collisional orogen. Earth Planet Sci Lett 173: $157-170$.

Ford M, Vergés J. 2020. Evolution of a salt-rich transtensional rifted margin, eastern North Pyrenees, France. Journal of the Geological Society 178: jgs2019-2157. https://doi.org/2010.1144/ jgs2019-2157.

Ford M, Duchêne S, Gasquet D, Vanderhaeghe O. 2006. Two-phase orogenic convergence in the external and internal SW Alps. J Geol Soc London 163: 815-826.

Ford M, Hemelsdaël R, Mancini M, Palyvos N. 2017. Rift migration and lateral propagation: evolution of normal faults and sedimentrouting systems of the western Corinth rift (Greece). Geological Society, London, Special Publications 439: 131-168. https://doi. org/10.1144/SP1439.1115.

Ford M, Hemmer L, Vacherat A, Gallagher K, Christophoul F. 2016. Retro-wedge foreland basin evolution along the ECORS line, eastern Pyrenees, France. Journal of the Geological Society 173: 419-437. https://doi.org/10.1144/jgs2015-1129.

Ford M, Williams EA, Malartre F, Popescu SP. 2007.Stratigraphic architecture, sedimentology and structure of the Vouraikos Gilberttype deltas, Gulf of Corinth, Greece. In: Paola C, Nichols GJ, Williams EA, eds. I. A. S. Special Publication 38: 49-90.
Frasca G, Dielforder A, Ford M, Vergés J. 2017. Cretaceous to Tertiary paleogeographic reconstructions of the Alps-Pyrenees linking zone. In: 19th EGU General Assembly, EGU2017, Vienna, Austria, 7021.

Forte AM, Quéré S, Moucha R, Simmons NA, Grand SP, Mitrovica $\mathrm{JX}$, et al. 2010. Joint seismic-geodynamic-mineral physical modelling of African geodynamics: A reconciliation of deepmantle convection with surface geophysical constraints. Earth Planet Sci Lett 295: 329-341. https://doi.org/10.1016/j. epsl.2010.1003.1017.

Fournier F, Tassy A, Thinon I, Münch P, Cornée JJ, Borgomano J, et al. 2016. Pre-Pliocene tectonostratigraphic framework of the Provence continental shelf (eastern Gulf of Lion, SE France). Bull Soc Géol Fr 187: 187-216.

Frizon de Lamotte D, Fourdan B, Leleu S, Leparmentier F, de Clarens P. 2015. Style of rifting and the stages of Pangea breakup. Tectonics 34: 1009-1029. https://doi.org/10.1002/2014TC003760.

Frizon de Lamotte D, Raulin C, Mouchot N, Wrobel-Daveau JC, Blanpied C, Ringenbach JC. 2011. The southernmost margin of the Tethys realm during the Mesozoic and Cenozoic: Initial geometry and timing of the inversion processes. Tectonics 30: TC3002. https://doi.org/10.1029/2010TC002691.

Frizon de Lamotte D, Saint Bezar B, Bracène R, Mercier E. 2000. The two main steps of the Atlas building and geodynamics of the West Mediterranean. Tectonics 19: 740-761.

Frizon de Lamotte D, Zizi M, Missenard Y, Hafid M, El Azzouzi M, Charriere A, et al. 2008. The Atlas system. In: Michard A, Saddiqi O, Chalouan A, Frizon de Lamotte D, eds. Continental Evolution: The Geology of Morocco. Heidelberg: Springer-Verlag, pp. 133202.

Funiciello F, Faccenna C, Giardini D, Regenauer-Lieb K. 2003. Dynamics of retreating slabs: 2 . insights from three-dimensional laboratory experiments. J Geophys Res 108: 2207. https://doi.org/ 10.1029/2001JB000896.

Gailler A, Klingelhoefer F, Olivet JL, Aslanian D, The Sardinia scientific party, Technical OBS team. 2009. Crustal structure of a young margin pair: New results across the Liguro-Provencal Basin from wide-angle seismic tomography. Earth and Planetary Science Letters 286: 333-345. https://doi.org/10.1016/j. eps1.2009.1007.1001.

Galindo-Zaldıvar J, Gil AJ, Borque MJ, Gonzalez-Lodeiro F, Jabaloy A, Marin-Lechado C, et al. 2003. Active faulting in the internal zones of the central Betic Cordilleras (SE, Spain). Journal of Geodynamics 36: 239-250.

Gawthorpe RL, Leeder MR, Kranis H, Skourtsos E, Andrews JE, Henstra GA, et al. 2018. Tectono-sedimentary evolution of the Plio-Pleistocene Corinth rift, Greece. Basin Research 30: 448-479. https://doi.org/10.1111/bre.12260.

Gebauer D, Schertl HP, Brix M, Schreyer W. 1997. 35 Ma old ultrahigh-pressure metamorphism and evidence for very rapid exhumation in the Dora Maira Massif, Western Alps. Lithos 41: 5 24.

Ghisetti F, Vezzani L. 2002. Normal faulting, transcrustal permeability and seismogenesis in the Apennines (Italy). Tectonophysics 348.

Glisovic P, Forte AM, Moucha R. 2012. Time-dependent convection models of mantle thermal structure constrained by seismic tomography and geodynamics: implications for mantle plume dynamics and CMB heat flux. Geophys J Int 190: 785-815. https:// doi.org/10.1111/j.1365-1246X.2012.05549.x.

Goffé B, Chopin C. 1986. High-pressure metamorphism in the Western Alps: zoneography of metapelites, chronology and consequences. Schweizerische Mineralogishe und Petrographische Mitteilungen 66: 41-52. 
Goffé B, Michard A, Garcia-Duenas V, Gonzales-Lodeiro F, Monié P, Campos J, et al. 1989. First evidence of high pressure, low temperature metamorphism in the Alpujarride nappes, Betic Cordillera (SE Spain). Eur J Miner 1: 139-142.

Goldberg JM, Leyreloup AF. 1990. High temperature-low pressure Cretaceous metamorphism related to crustal thinning (Eastern North Pyrenean Zone, France). Contr Miner Petrol 104: 194-207.

Gómez-Pugnaire MT, Rubatto D, Fernández-Soler JM, Jabaloy A, López-Sánchez-Vizcaíno V, González-Lodeiro F, et al. 2012. Late Variscan magmatism in the Nevado-Filábride Complex: U-Pb geochronologic evidence for the pre-Mesozoic nature of the deepest Betic complex (SE Spain). Lithos 146-147: 93-111. https://doi.org/10.1016/j.lithos.2012.1003.1027.

Gorini C, Le Marrec A, Mauffret A. 1993. Contribution to the structural and sedimentary history of the Gulf of Lions (western Mediterranean), from the ECORS profiles, industrial seismic profiles and weIl data. Bull Geol Soc Fr 164: 353-363.

Gorini C, Mauffret A, Guennoc P, Le Marrec A. 1994. Structure of the Gulf of Lions (Northwestern Mediterranean Sea): a review. In: Mascle A, ed. Hydrocarbon and Petroleum Geology of France. Springer-Verlag, pp. 223-243.

Govers R, Wortel MJR. 2005. Lithosphere tearing at STEP faults: Response to edges of subduction zones. Earth Planet Sci Lett 236: 505-523.

Granado P, Urgeles R, Sàbat F, Albert-Villanueva E, Roca E, Muñoz JA, et al. 2016. Geodynamical framework and hydrocarbon plays of a salt giant: the NW Mediterranean Basin. Petroleum Geoscience 22: 309-321. https://doi.org/10.1144/petgeo2015-1084.

Granot R. 2016. Palaeozoic oceanic crust preserved beneath the eastern Mediterranean. Nature Geoscience 9: 701-706. https://doi. org/10.1038/NGEO2784.

Grool AR, Ford M, Vergés J, Huismans RS, Christophoul F, Dielforder A. 2018. Insights into the crustal-scale dynamics of a doubly vergent orogen from a quantitative analysis of its forelands: A case study of the Eastern Pyrenees. Tectonics 37: 450-476. https://doi.org/10.1002/2017TC004731.

Grool AR, Huismans RS, Ford M. 2019. Salt décollement and rift inheritance controls on crustal deformation in orogens. Terra Nova 31: 562-568. https://doi.org/10.1111/ter.12428.

Grosheny D, Ferry S, Courjault S. 2015. Progradational patterns at the head of single units of base-of-slope, submarine granular flow deposits ("Conglomérats des Gâs", Coniacian, SE France). Sedimentary Geology 317: 102-115, 0037-0738. https://doi.org/ 10.1016/j.sedgeo.2014.0010.0007.

Gueguen E, Doglioni C, Fernandez M. 1998. On the post-25 Ma geodynamic evolution of the western Mediterranean. Tectonophysics 298: 259-269.

Guennoc P, Gorini C, Mauffret A. 2000. Histoire géologique du golfe $\mathrm{du}$ Lion et cartographie du rift oligo-aquitanien et de la surface messinienne. Géologie de la France 3: 67-97.

Guillocheau F, Robin C, Allemand P, Bourquin S, Brault N, Dromart $\mathrm{G}$, et al. 2000. Meso-cenozoic geodynamic evolution of the Paris basin, stratigraphic constraints. Geodynamica Acta 13: 189-246.

Guillaume B, Funiciello F, Faccenna C, Martinod J, Olivetti V. 2010. Spreading pulses of the Tyrrhenian Sea during the narrowing of the Calabrian slab. Geology 38: 819-822. https://doi.org/10.1130/ G31038.31031.

Guiraud R, Bosworth W, Thierry J, Delplanque A. 2005. Phanerozoic geological evolution of Northern and Central Africa: An overview. Journal of African Earth Sciences 43: 83-143.

Gunnell Y, Calvet M, Brichau S, Carter A, Aguilar JP, Zeyen H. 2009. Low long-term erosion rates in high-energy mountain belts: Insights from thermo- and biochronology in the Eastern Pyrenees. Earth Planet Sci Lett 278: 208-218. https://doi.org/10.1016/j.epsl.2008.1012.1004.

Gutscher MA, Kopp H, Krastel S, Bohrmann G, Garlan T, Zaragosi S, et al. 2017. Active tectonics of the Calabrian subduction revealed by new multi-beam bathymetric data and high-resolution seismic profiles in the Ionian Sea (Central Mediterranean). Earth and Planetary Science Letters 461: 61-72. https://doi.org/10.1016/j. epsl.2016.1012.1020.

Gutscher MA, Malod J, Rehault JP, Contrucci I, Klingelhoefer F, Mendes-Victor L, et al. 2002. Evidence for active subduction beneath Gibraltar. Geology 30: 1071-1074.

Handy MR, Schmid SM, Bousquet R, Kissling E, Bernoulli D. 2010. Reconciling plate-tectonic reconstructions of Alpine Tethys with the geological-geophysical record of spreading and subduction in the Alps. Earth-Science Reviews 102: 121-158. https://doi.org/ 10.1016/j.earscirev.2010.1006.1002.

Heidbach O, Rajabi M, Cui X, Fuchs K, Müller B, Reinecker J, et al. 2018. The World Stress Map database release 2016: Crustal stress pattern across scales. Tectonophysics 744: 484-498.

Hennuy J. 2003. Sédimentation carbonate et silicoclastique sous contrôle tectonique, le bassin sud-provençal et sa plate-forme carbonatée du Turonien au Coniacien moyen. Évolution séquentielle, diagénétique, paléogéographique. Marseille: Aix-Marseille Univ., Centre Saint-Charles, 252 p.

Hernandez J, de Larouzière FD, Bolze J, Bordet P. 1987. Le magmatisme néogène bético-rifain et le couloir de décrochement trans-Alboran. Bull Soc Géol Fr 8: 257-267.

Huyghe D, Mouthereau F, Ségalen L, Furio M. 2020. Long-term dynamic topographic support during post-orogenic crustal thinning revealed by stable isotope $(\delta 180)$ paleo-altimetry in eastern Pyrenees. Scientific Reports 10: 2267. https://doi.org/10.1038/ s41598-41020-58903-w.

Issautier B, Saspiturry N, Serrano O. 2020. Role of structural inheritance and salt tectonics in the formation of pseudosymmetric continental rifts on the european margin of the hyperextended Mauléon basin (Early Cretaceous Arzacq and Tartas Basins). Marine and Petroleum Geology 118: 104395. https://doi.org/ 10.101016/j.marpetgeo.102020.104395.

Issautier B, Lasseur E, Serrano O. 2018. Onset of the Convergence between Europe and Iberia: Well correlation and seismic interpretation within the Upper Cretaceous of the Aquitaine Basin. In: 26e Réunion des Sciences de la Terre, Lille.

Izquierdo-Llavall E, Menant A, Aubourg C, Callot JP, Hoareau G, Camps P, et al. 2020. Pre-orogenic folds and syn-orogenic basement tilts in an inverted hyperextended margin: the northern Pyrenees case study. Tectonics. https://doi.org/10.1029/ 2019TC005719 (in press).

Jabaloy A, Galindo-Saldivar J, Gonzales-Lodeiro F. 1993. The Alpujarride-Nevado-Filabride extensional shear zone, Betic Cordillera, SE Spain. J Struct Geol 15: 555-569.

Jammes S, Lavier L, Manatschal G. 2010a. Extreme crustal thinning in the Bay of Biscay and the Western Pyrenees: From observations to modeling. Geochem Geophys Geosyst 11: Q10016. https://doi. org/10010.11029/12010GC003218.

Jammes S, Tiberi C, Manatschal G. 2010b. 3D architecture of a complex transcurrent rift system: The example of the Bay of Biscay-Western Pyrenees. Tectonophysics 489: 210-226. https:// doi.org/10.1016/j.tecto.2010.1004.1023.

Janowski M, Loget N, Gautheron C, Barbarand J, Bellahsen N, Van Den Driessche J, et al. 2017. Neogene exhumation and relief evolution in the eastern Betics (SE Spain): Insights from the Sierra de Gador. Terra Nova: 1-7. https://doi.org/10.1111/ter.12252. 
Jolivet L, Augier R, Faccenna C, Negro F, Rimmele G, Agard P, et al. 2008. Subduction, convergence and the mode of backarc extension in the Mediterranean region. Bull Soc Géol Fr 179: 525-550.

Jolivet L, Augier R, Robin C, Suc JP, Rouchy JM. 2006. The geodynamic context of the Messinian salinity crisis. Sedimentary Geology 188-189: 9-33.

Jolivet L, Brun JP. 2010. Cenozoic geodynamic evolution of the Aegean region. Int $J$ Earth Sci 99: 109-138. https://doi.org/ 10.1007/s00531-00008-00366-00534.

Jolivet L, Daniel JM, Fournier M. 1991. Geometry and kinematics of ductile extension in alpine Corsica. Earth and Planetary Science Letters 104: 278-291.

Jolivet L, Daniel JM, Truffert C, Goffé B. 1994. Exhumation of deep crustal metamorphic rocks and crustal extension in back-arc regions. Lithos 33: 3-30. https://doi.org/10.1016/0024-4937(1094) 90051-90055.

Jolivet L, Dubois R, Fournier M, Goffé B, Michard A, Jourdan C. 1990. Ductile extension in Alpine Corsica. Geology 18: 10071010.

Jolivet L, Faccenna C. 2000. Mediterranean extension and the AfricaEurasia collision. Tectonics 19: 1095-1106. https://doi.org/ 10.1029/2000TC900018.

Jolivet L, Faccenna C, Agard P, Frizon de Lamotte D, Menant A, Sternai $\mathrm{P}$, et al. 2016a. Neo-Tethys geodynamics and mantle convection: from extension to compression in Africa and a conceptual model for obduction. Can J Earth Sci 53: 1190-1204. https://doi.org/10.1110.1139/cjes-2015-0118.

Jolivet L, Faccenna C, Becker TW. 2016b. Mantle flow and deforming continents, the Tethys realm. In: AGU Fall Meeting, San Francisco, pp. T53B-07.

Jolivet L, Faccenna C, Goffé B, Burov E, Agard P. 2003. Subduction tectonics and exhumation of high-pressure metamorphic rocks in the Mediterranean orogens. Am J Sci 303: 353-409. https://doi.org/ 10.2475/ajs.2303.2475.2353.

Jolivet L, Faccenna C, Goffé B, Mattei M, Rossetti F, Brunet C, et al. 1998. Mid-crustal shear zones in post-orogenic extension: the northern Tyrrhenian Sea case. J Geophys Res 103: 12123-12160. https://doi.org/10.11029/12197JB03616.

Jolivet L, Faccenna C, Huet B, Labrousse L, Le Pourhiet L, Lacombe O, et al. 2013. Aegean tectonics: progressive strain localisation, slab tearing and trench retreat. Tectonophysics 597-598: 1-33. https://doi.org/10.1016/j.tecto.2012.1006.1011.

Jolivet L, Faccenna C, Piromallo C. 2009. From Mantle to crust: stretching the Mediterranean. Earth Planet Sci Lett 285: 198-209. https://doi.org/10.1016/j.epsl.2009.1006.1017.

Jolivet L, Famin V, Mehl C, Parra T, Aubourg C, Hébert R, et al. 2004. Strain localization during crustal-scale boudinage to form extensional metamorphic domes in the Aegean Sea. In: Whitney DL, Teyssier C, Siddoway CS, eds. Gneiss domes in orogeny. Boulder, Colorado: Geological Society of America, pp. 185-210.

Jolivet L, Gorini C, Bache F, Smit J, Leroy S. 2012. Continental Break-up and the dynamics of rifting in backarc basins: the Gulf of Lions margin. In: EGU General Assembly 2012, Vienna, pp. EGU2012-1756.

Jolivet L, Gorini C, Smit J, Leroy S. 2015a. Continental breakup and the dynamics of rifting in back-arc basins: The Gulf of Lion margin. Tectonics 34. https://doi.org/10.1002/2014TC003570.

Jolivet L, Menant A, Clerc C, Sternai P, Bellahsen N, Leroy S, et al. 2018. Extensional crustal tectonics and crust-mantle coupling, a view from the geological record. Earth Science Reviews 185: 1187 1209. https://doi.org/10.1016/j.earscirev.2018.1109.1010.

Jolivet L, Menant A, Roche V, Le Pourhiet L, Maillard A, Augier R, et al. 2021. Transfer zones in Mediterranean back-arc regions and tear faults. BSGF - Earth Sciences Bulletin 192: 11. https://doi. org/10.1051/bsgf/2021006.

Jolivet L, Menant A, Sternai P, Rabillard A, Arbaret L, Augier R, et al. $2015 \mathrm{~b}$. The geological signature of a slab tear below the Aegean. Tectonophysics 659: 166-182. https://doi.org/10.1016/j. tecto.2015.1008.1004.

Jolivet L, Romagny A, Gorini C, Maillard A, Thinon I, Couëffé R, et al. 2020. Fast dismantling of a mountain belt by mantle flow: late-orogenic evolution of Pyrenees and Liguro-Provençal rifting. Tectonophysics 776: 228312. https://doi.org/10.221016/j. tecto.222019.228312.

Jolivet M, Labaume P, Monié P, Brunel M, Arnaud N, Campani M. 2007. Thermochronology constraints for the propagation sequence of the south Pyrenean basement thrust system (France-Spain). Tectonics 26: TC5007. https://doi.org/10.1029/2006TC002080.

Jourdon A, Le Pourhiet L, Mouthereau F, Masini E. 2019. Role of rift maturity on the architecture and shortening distribution in mountain belts. Earth and Planetary Science Letters 512: 8999. https://doi.org/10.1016/j.epsl.2019.1001.1057.

Jourdon A, Mouthereau F, Le Pourhiet L, Callot JP. 2020. Topographic and tectonic evolution of mountain belts controlled by salt thickness and rift architecture. Tectonics 39: e2019TC005903. https://doi.org/10.001029/002019TC005903.

Keller JV, Pialli G. 1990. Tectonics of the island of Elba: a reappraisal. Boll Soc Geol It 109: 413-425.

Kirchner KL, Behr W, Loewy S, Stockli DF. 2015. Early Miocene subduction in the Western Mediterranean: constraints from $\mathrm{Rb}-\mathrm{Sr}$ multi-mineral isochron geochronology. Geochemistry, Geophysics, Geosystems. https://doi.org/10.1002/2015GC006208.

Kley J, Voigt T. 2008. Late Cretaceous intraplate thrusting in central Europe: Effect of Africa-Iberia-Europe convergence, not Alpine collision. Geology 36: 839-842. https://doi.org/10.1130/ G24930A.24931.

Koptev A, Beniest A, Gerya T, Ehlers TA, Jolivet L, Leroy S. 2019. Plume-induced breakup of a subducting plate: Microcontinent formation without cessation of the subduction process. Geophysical Research Letters 46. https://doi.org/10.1029/2018GL081295.

Koptev A, Burov E, Gerya T, Le Pourhiet L, Leroy S, Calais E, et al. 2017. Plume-induced continental rifting and break-up in ultra-slow extension context: Insights from 3D numerical modeling. Tectonophysics. https://doi.org/10.1016/j.tecto.2017.1003.1025.

Koptev A, Calais E, Burov E, Leroy S, Gerya T. 2015. Dual continental rift systems generated by plume-lithosphere interaction. Nature Geoscience 8: 388-392. https://doi.org/10.1038/ NGEO2401.

Kornprobst J, Vielzeuf D. 1984. Transcurrent crustal thinning: a mechanism for the uplift of deep continental crust/upper mantle associations. In: Kornprobst J, ed. Kimberlites and related rocks. Elsevier, pp. 347-359.

Kuhlemann J, Frisch W, Székely B, Dunk1 I, Kázmér M. 2002. Postcollisional sediment budget tectonic versus climatic control. Int $J$ Earth Sci 91: 818-837.

Kuhlemann J, Kempf O. 2002. Post-eocene evolution of the north alpine foreland basin and its response to alpine tectonics. Sedimentary Geology 152: 45-78.

Labaume P, Meresse F, Jolivet M, Teixell A, Lahfid A. 2016. Tectonothermal history of an exhumed thrust-sheet-top basin: An example from the south Pyrenean thrust belt. Tectonics 35: 1280 1313. https://doi.org/10.1002/2016TC004192.

Labaume P, Teixell A. 2020. Evolution of salt structures of the Pyrenean rift (Chaînons Béarnais, France): From hyper-extension to tectonic inversion. Tectonophysics 785: 22845. https://doi.org/ 10.1016/j.tecto.2020.228451. 
Lacombe O, Jolivet L. 2005. Structural and kinematic relationships between Corsica and the Pyrenees-Provence domain at the time of the Pyrenean orogeny. Tectonics 24: TC1003. https://doi.org/ 10.1129/2004TC001673.

Lafosse M, d'Acremont E, Rabaute A, Estrada F, Jollivet-Castelot M, Vazquez JT, et al. 2020. Plio-Quaternary tectonic evolution of the southern margin of the Alboran Basin (Western Mediterranean). Solid Earth 11: 741-765. https://doi.org/10.5194/se-5111-57412020.

Lafosse M, Gorini C, Le Roy P, Alonso B, d'Acremont E, Ercilla G, et al. 2018. Late Pleistocene-Holocene history of a tectonically active segment of the the continental margin (Nekor basin, Western Mediterranean, Morocco). Marine and Petroleum Geology 97: 370-389. https://doi.org/10.1016/j.marpetgeo.2018.1007.1022.

Lagabrielle Y, Asti R, Fourcade S, Corre B, Labaume P, Uzel J, et al. 2019a. Mantle exhumation at magma-poor passive continental margins. Part II: Tectonic and metasomatic evolution of largedisplacement detachment faults preserved in a fossil distal margin domain (Saraillé lherzolites, northwestern Pyrenees, France). BSGF - Earth Sciences Bulletin 190: 14. https://doi.org/ 10.1051/bsgf/2019013.

Lagabrielle Y, Asti R, Fourcade S, Corre B, Poujol M, Uzel J, et al. 2019b. Mantle exhumation at magma-poor passive continental margins. Part I. 3D architecture and metasomatic evolution of a fossil exhumed mantle domain (Urdach lherzolite, north-western Pyrenees, France). BSGF - Earth Sciences Bulletin 190: 8. https:// doi.org/10.1051/bsgf/2019007.

Lagabrielle Y, Bodinier JL. 2008. Submarine reworking of exhumed subcontinental mantle rocks: field evidence from the Lherz peridotites, French Pyrenees. Terra Nova 20: 11-21. https://doi. org $/ 10.1111 / j .1365-3121.2007 .00781 . x$.

Lagabrielle Y, Labaume P, de Saint Blanquat M. 2010. Mantle exhumation, crustal denudation, and gravity tectonics during Cretaceous rifting in the Pyrenean realm (SW Europe): insights from the geological setting of the lherzolite bodies. Tectonics 29. https://doi.org/10.1029/2009TC002588.

Lanari R, Faccenna C, Fellin MG, Abderrahim E, Nahid A, Medina F, et al. 2020a. Tectonic evolution of the Western High Atlas of Morocco: oblique convergence, reactivation and transpression. Tectonics 39: e2019TC005563. https://doi.org/10.1029/ 2019TC005563.

Lanari R, Fellin MG, Faccenna C, Balestrieri ML, Pazzaglia F, Youbi $\mathrm{N}$, et al. 2020b. Exhumation and surface evolution of the Western High-Atlas and surrounding regions as constrained by lowtemperature thermochronology. Tectonics 39(3): e2019TC005562. https://doi.org/10.1029/2019TC005562.

Lasseur E. 2007. La Craie du Bassin de Paris (CénomanienCampanien, Crétacé supérieur). Sédimen- tologie de faciès, stratigraphie séquentielle et géométrie 3D. Rennes: Université de Rennes 1.

Lavecchia G. 1988. The Tyrrhenian-Apennines system: Structural setting and seismotectogenesis. Tectonophysics 147: 263-296.

Lavier LL, Ball PJ, Manatschal G, Heumann MJ, MacDonald J, Matt VJ, et al. 2019. Controls on the thermomechanical evolution of hyperextended lithosphere at magma-poor rifted margins: The example of Espirito Santo and the Kwanza basins. Geochemistry, Geophysics, Geosystems 20. https://doi.org/10.1029/ 2019GC008580.

Lavier LL, Buck WR, Poliakov ANB. 1999. Self-consistent rollinghinge model for the evolution of large-offset low-angle normal faults. Geology 27: 1127-1130.

Lehujeur M, Chevrot S, Villaseñor A, Masini E, Saspiturry N, Lescoutre R, et al. 2021. Three-dimensional shear velocity structure of the Mauleon and Arzacq basins (Western Pyrenees). BSGF-Earth Sciences Bulletin 210003. https://doi.org/10.1051/ bsgf/2021039.

Le Pichon X. 1982. Land-locked oceanic basins and continental collision, the eastern Mediterranean as a case example. In: Hsue KJ, ed. Mountain building processes. London: Academic Press, pp. 201-211.

Le Pourhiet L, Huet B, May D, Labrousse L, Jolivet L. 2012. Kinematic interpretation of the 3D shapes of metamorphic core complexes. Geochem Geophys Geosyst 13(9): Q09002. https://doi. org/10.01029/02012GC004271.

Leprêtre R, Frizon de Lamotte D, Combier V, Gimeno-Vives O, Mohn G, Eschard R. 2018. The Tell-Rif orogenic system (Morocco, Algeria, Tunisia) and the structural heritage of the southern Tethys margin. BSGF - Earth Sciences Bulletin 189: 10. https://doi.org/ $10.1051 / \mathrm{bsgf} / 2018009$.

Lescoutre R, Manatschal G. 2020. Role of rift-inheritance and segmentation for orogenic evolution: example from the PyreneanCantabrian system. BSGF - Earth Sciences Bulletin 191: 18. https://doi.org/10.1051/bsgf/2020021.

Lescoutre R, Tugend J, Brune S, Masini E, Manatschal G. 2019. Thermal evolution of asymmetric hyperextended magma-poor rift systems: Results from numerical modeling and Pyrenean field observations. Geochemistry, Geophysics, Geosystems 20: 45674587. https://doi.org/10.1029/2019GC008600.

Li B, Massonne HJ. 2018. Two Tertiary metamorphic events recognized in high-pressure metapelites of the Nevado-Filábride Complex (Betic Cordillera, S. Spain). J Metam Geol 36: 603-630.

Lonergan L, Platt JP. 1995. The Malaguide-Alpujarride boundary: a major extensional contact in the internal zones of the eastern Betic Cordillera, SE Spain. J Struct Geol 17: 1655-1671.

Lonergan L, White N. 1997. Origin of the Betic-Rif mountain belt. Tectonics 16: 504-522.

López Sánchez-Vizcaíno V, Rubatto D, Gómez-Pugnaire MT, Trommsdorff V, Müntener O. 2001. Middle Miocene high-pressure metamorphism and fast exhumation of the Nevado-Filábride complex, SE Spain. Terra Nova 13: 327-332.

Lucente FP, Margheriti L, Piromallo C, Barruol G. 2006. Seismic anisotropy reveals the long route of the slab through the westerncentral Mediterranean mantle. Earth Plaonet Sci Lett 241: 517-529.

Macchiavelli C, Vergés J, Schettino A, Fernàndez M, Turco E, Casciello E, et al. 2018. A new southern North Atlantic isochron map: insights into the drift of the Iberian plate since the Late Cretaceous. Journal of Geophysical Research: Solid Earth 122: 9603-9626. https://doi.org/10.1002/2017JB014769.

Maillard A, Jolivet L, Lofi J, Couëffé R, Thinon I. 2020. Transfer Faults and associated volcanic province in the transition zone between the Valencia Basin and the Gulf of Lion: consequences on crustal thinning. Marine and Petroleum Geology 119. https://doi. org/10.1016/j.marpetgeo.2020.104419,104419.

Maillard A, Mauffret A. 1999. Crustal structure and riftogenesis of the Valencia Trough (north-western Mediterranean Sea). Basin Res 11: 357-379.

Maillard A, Mauffret A. 2013. Structure and present-day compression in the offshore area between Alicante and Ibiza Island (Eastern Iberian Margin). Tectonophysics 591: 116-130. https://doi.org/ 10.1016/j.tecto.2011.1007.1007.

Malinverno A, Ryan W. 1986. Extension in the Tyrrhenian sea and shortening in the Apennines as result of arc migration driven by sinking of the lithosphere. Tectonics 5: 227-245.

Maluski H, Bonneau M, Kienast JR. 1987. Dating the metamorphic events in the Cycladic area: 39Ar/40Ar data from metamorphic rocks of the island of Syros (Greece). Bull Géol Soc Fr 8: 833-842. 
Manatschal G, Chenin P, Lescoutre R, Miró J, Cadenas P, Saspiturry $\mathrm{N}$, et al. 2021. The role of inheritance in forming rifts and rifted margins and building collisional orogens: a Biscay-Pyrenean perspective. BSGF - Earth Sciences Bulletin 200015. https://doi. org $/ 10.1051 / \mathrm{bsgf} / 2021042$.

Mantovani E, Babbucci D, Tamburelli C, Viti M. 2009. A review on the driving mechanism of the Tyrrhenian-Apennines system: Implications for the present seismotectonic setting in the CentralNorthern Apennines. Tectonophysics 476: 22-40. https://doi.org/ 10.1016/j.tecto.2008.1010.1032.

Mantovani E, Viti M, Babbucci D, Tamburelli C, Cenni N. 2020. Geodynamics of the central-western Mediterranean region: plausible and non-plausible driving forces. Marine and Petroleum Geology 113: 104121.

Martínez-García P, Comas M, Lonergan L, Watts AB. 2017. From extension to shortening: Tectonic inversion distributed in time and space in the Alboran sea, western Mediterranean. Tectonics 36: 2777-2805. https://doi.org/10.1002/2017TC004489.

Martinez-Martinez JM, Azañon JM. 1997. Mode of extensional tectonics in the southeastern Betics (SE Spain): implications for the tectonic evolution of the peri-Alboran orogenic system. Tectonics 16: 205-225.

Mascle A, Jacquart G, Deville E. 1994. The Corbières transverse zone of the Pyrenees-Provence thrust belt (south France)-Tectonic history and petroleum. In: Paper presented at 6th Conference, Eur. Assoc. of Pet. Geosci. and Eng., Vienna.

Masini E, Manatschal G, Tugend J, Mohn G, Flament JM. 2014. The tectono-sedimentary evolution of a hyper-extended rift basin: the example of the Arzacq-Mauléon rift system (Western Pyrenees, SW France). Int J Earth Sci (Geol Rundsch) 103: 1569-1596. https://doi.org/10.1007/s00531-00014-01023-00538.

Mauffret A, Frizon de Lamotte D, Lallemant S, Gorini C, Maillard A. 2004. E-W opening of the Algerian basin (Western Mediterranean). Terra Nova 16: 257-264.

Mauffret A, Pascal G, Maillard A, Gorini C. 1995. Tectonics and deep structure of the north-western Mediterranean basin. Marine and Petroleum Geology 12: 645-666.

Maurel O, Brunel M, Monié P. 2002. Exhumation cénozoïque des massifs du Canigou et de Mont-Louis (Pyrénées orientales, France). C R Geosci 334: 941-948.

McClusky S, Balassanian S, Barka A, Demir C, Ergintav S, Georgiev I, et al. 2000. Global Positioning System constraints on plate kinematics and dynamics in the eastern Mediterranean and Caucasus. J Geophys Res 105: 5695-5720.

McKenzie DP. 1969. Speculations on the conséquences and causes of plate motions. Geophys J R Astron Soc 18: 1-32.

Meghraoui M, Cisternas A, Philip H. 1986. Seismotectonics of the lower Cheliff basin: structural background of the El Asnam (Algeria) earthquake. Tectonics 5: 809-836.

Medaouri M, Déverchère $\mathrm{J}$, Graindorge $\mathrm{D}$, Bracene R, Badjia R, Ouabadic A, et al. 2014. The transition from Alboran to Algerian basins (Western Mediterranean Sea): Chronostratigraphy, deep crustal structure and tectonic evolution at the rear of a narrow slab rollback system. Journal of Geodynamics 77: 186-205. https://doi. org/10.1016/j.jog.2014.1001.1003.

Meghraoui M, Morel JL, Andrieux J, Dahmani M. 1996. Tectonique plio-quaternaire de la chaîne tello-rifaine et de la mer d'Alboran. Une zone complexe de convergence continent-continent. Bull Soc Géol Fr 167: 141-157.

Meghraoui M, Pondrelli S. 2012. Active faulting and transpression tectonics along the plate boundary in North Africa. Annals of Geophysics 55. https://doi.org/10.4401/ag-4970.

Meijninger BML, Vissers RLM. 2006. Miocene extensional basin development in the Betic Cordillera, SE Spain revealed through analysis of the Alhama de Murcia and Crevillente Faults. Basin Research 18: 547-571. https://doi.org/10.1111/ j.1365-2117.2006.00308.x.

Menant A, Aubourg C, Cuyala JB, Hoareau G, Callot JP, Péré E, et al. 2016. Salt tectonics and thermal imprint along an inverted passive margin: the Montcaou anticline, Chaînons Béarnais, North Pyrenean Zone. In: EGU General Assembly 2016, Vienna, pp. EPSC2016-15281.

Merle O, Michon L. 2001. The formation of the West European Rift: a new model as exemplified by the Massif Central Area. Bull Soc Géol Fr 172: 213-221.

Michard A, Chalouan A, Feinberg H, Goffé B, Montigny R. 2002. How does the Alpine belt end between Spain and Morocco? Bull Geol Soc Fr 173: 3-15.

Milesi G. 2020. Analyse thermochronologique, géochimique et structurale du système hydrothermal de la faille de la Têt (Pyrénées, France), un nouvel outil d'exploration géothermique. Montpellier: Université de Montpellier, p. 503.

Miller C, Thöni M. 1997. Eo-Alpine eclogitisation of Permian MORB-type gabbros in the Koralpe (Eastern Alps, Austria): new geochronological, geochemical and petrological data. Chemical Geology 137: 283-310.

Miró J. 2020. Rift-inheritance, segmentation and reactivation of the North Iberian rift system in the Basque - Cantabrian Pyrenees. PhD thesis. Strasbourg: Université de Strasbourg and Universitat Barcelona, $228 \mathrm{p}$.

Miró J, Muñoz JA, Manatschal G, Roca E. 2020. The Basque Cantabrian Pyrenees: report of data analysis. BSGF - Earth Sciences Bulletin 191: 22. https://doi.org/10.1051/bsgf/2020024.

Missenard Y, Cadoux A. 2012. Can Moroccan Atlas lithospheric thinning and volcanism be induced by Edge-Driven Convection? Terra Nova 24: 27-33. https://doi.org/10.1111/ j.1365-3121.2011.01033.x.

Molnar P, Lyon-Caen H. 1988. Some simple physical aspects of the support, structure, and evolution of mountain belts. Geol Soc Am Spec Pap 218: 179-207.

Molnar P, Tapponnier P. 1975. Cenozoic tectonics of Asia: Effects of a continental collision. Science 189: 419-426.

Monié P, Lodeiro FG, Goffé B, Jabaloy A. 1991. 39Ar/40Ar geochronology of alpine tectonism in the Betic Cordillera (Southern Spain). J Geol Soc Lond 148: 289-297.

Monod B, Regard V, Carcone J, Wyns R, Christophoul F. 2016. Postorogenic planar palaeosurfaces of the central Pyrenees: Weathering and neotectonic records. C R Geosci 348: 184-193. https://doi.org/10.1016/j.crte.2015.1009.1005.

Morris RG, Sinclair HD, Yelland AJ. 1998. Exhumation of the Pyrenean orogen: implications for sediment discharge. Basin Research 10: 69-85.

Moucha R, Forte AM. 2011. Changes in African topography driven by mantle convection. Nature Geoscience 4: 707-712. https://doi. org/10.1038/NGEO1235.

Moulin M, Klingelhoeffer F, Afilhado A, Aslanian A, Schnurle P, Nouzé $\mathrm{H}$, et al. 2015. Deep crustal structure across a young passive margin from wide-angle and reflection seismic data (The SARDINIA Experiment) - I. Gulf of Lion's margin. Bull Soc Géol Fr 186: 309-330.

Mouthereau F, Filleaudeau PY, Vacherat A, Pik R, Lacombe O, Fellin MG, et al. 2014. Placing limits to shortening evolution in the Pyrenees: Role of margin architecture and implications for the Iberia/Europe convergence. Tectonics 33: 2283-2314. https://doi. org/10.1002/2014TC003663.

Mouthereau F, Angrand P, Jourdon A, Ternois S, Fillon C, Calassou S, et al. 2021. Cenozoic mountain building and topographic evolution in Western Europe: impact of billion years lithosphere evolution 
and plate tectonics. BSGF-Earth Sciences Bulletin 210026. https:// doi.org/10.1051/bsgf/2021040.

Mouthereau F, Watts AB, Burov E, 2013. Structure of orogenic belts controlled by lithosphere age. Nature Geoscience 6. https://doi.org/ 10.1038/NGEO1902.

Muñoz JA. 2002. The Pyrenees. In: Gibbons W, Moreno T, eds. The Geology of Spain. The Geological Society of London, pp. 370-385.

Muñoz JAE. 1992. Evolution of a continental collision belt: ECORSPyrenees crustal balanced cross-section. In: McClay K, ed. Thrust Tectonics. London: Chapman and Hall, pp. 235-246.

Muñoz JA, Beamud E, Fernandez $\mathrm{O}$, Arbués $\mathrm{P}$, Dinarès-Turell J, Poblet J. 2013. The Ainsa Fold and thrust oblique zone of the central Pyrenees: Kinematics of a curved contractional system from paleomagnetic and structural data. Tectonics 32: 1142-1175. https://doi.org/10.1002/tect.20070.

Muñoz JA, Mencos J, Roca E, Carrera N, Gratacós O, Ferrer O, et al. 2018. The structure of the South-Central-Pyrenean fold and thrust belt as constrained by subsurface data. Geologica Acta 16: 439460. https://doi.org/10.1344/GeologicaActa2018.1316.1344.1347.

Nadin PA, Kusznir NJ, Cheadle MJ. 1997. Early Tertiary plume uplift of the North Sea and Faeroe-Shetland Basins. Earth Planet Sci Lett 148: 109-127.

Nielsen SB, Paulsen GE, Hansen DL, Gemmer L, Clausen OR, Jacobsen BH, et al. 2002. Paleocene initiation of Cenozoic uplift in Norway. In: Doré AG, Cartwright JA, Stocker MS, Turner JE, White N, eds. Exhumation of the North Atlantic margin: timing, mechanisms and implications for petroleum exploration. Geological Society, London, Special Publications 196: 45-65.

Nirrengarten M, Manatschal G, Tugend J, Kusznir J, Sauter D. 2018. Kinematic evolution of the southern North Atlantic: Implications for the formation of hyperextended rift systems. Tectonics 37: 89118. https://doi.org/10.1002/2017TC004495.

Oberhänsli R, Bousquet R, Engi M, Goffé B, Gosso G, Handy M, et al. 2004. Metamorphic structure of the Alps, edited by the Commission for the Geological Map of the World. Miit Österr Geol Ges 149.

Ortiz A. 2019. Géométries et bilan érosion-sédimentation d'un rétrobassin d'avant- pays durant son évolution finie-orogénique et postorogénique: le cas du système Pyrénées/bassin d'Aquitaine/golfe de Gascogne de 38 à 0 Ma. Rennes: Université de Rennes 1, pp. 310.

Ortiz A, Guillocheau F, Lasseur E, Briais J, Robin C, Serrano O, et al. 2020. Sediment routing system and sink preservation during the post-orogenic evolution of a retro-foreland basin: The case example of the North Pyrenean (Aquitaine, Bay of Biscay) Basins. Marine and Petroleum Geology 112: 104085. https://doi.org/ 10.101016/j.marpetgeo.102019.104085.

Parizot O, Missenard Y, Haurine F, Blaise T, Barbarand J, Benedicto A, et al. 2021. When did the Pyrenean shortening end? Insight from $\mathrm{U}-\mathrm{Pb}$ geochronology of syn-faulting calcite (Corbières area, France). Terra Nova 00: 1-9. https://doi.org/10.1111/ter.12547.

Pascal GP, Mauffret A, Patriat P. 1993. The ocean-continent boundary in the Gulf of Lion from analysis of expanding spread profiles and gravity modelling. Geophysical Journal International 113: 701726.

Patacca E, Scandone S. 1989. Post-Tortonian mountain building in the Apennines. The role of the passive sinking of a relic lithospheric slab. In: Boriani A, Bonafede M, Piccardo GB, Vai GB, eds. The lithosphere in Italy. Advances in science research. Rome: Accademia Nazionale dei Lincei, pp. 157-176.

Patacca E, Sartori R, Scandone P. 1990. Tyrrhenian basin and Apenninic arcs: kinematic relations since late Tortonian times. Mem Soc Geol It 45: 425-451.
Pauselli C, Ranalli G. 2017. Effects of lateral variations of crustal rheology on the occurrence of post- orogenic normal faults: The Alto Tiberina Fault (Northern Apennines, Central Italy). Tectonophysics 721: 45-55. https://doi.org/10.1016/j. tecto.2017.1009.1008.

Pauselli C, Barchi MR, Federico C, Magnani MB, MInelli G. 2006. The crustal structure of the Northern Apennines (Central Italy): an insight by the CROP03 seismic line. American Journal of Science 306: 428-450. https://doi.org/10.2475/2406.2006.2402.

Pedrera A, Ruiz-Constán A, García-Senz J, Azor A, Marín-Lechado C, Ayala C, et al. 2020. Evolution of the South-Iberian paleomargin: From hyperextension to continental subduction. Journal of Structural Geology 138: 104122. https://doi.org/ 10.101016/j.jsg.102020.104122.

Pellen R, Aslanian D, Rabineau M, Leroux E, Gorini C, Silenziario C, et al. 2016. The Minorca Basin: a buffer zone between the Valencia and Liguro-Provençal Basins (NW Mediterranean Sea). Terra Nova 28: 245-256. https://doi.org/10.1111/ter.12215.

Pérez-Peña JV, Azor A, Azañón JM, Keller EA. 2010. Active tectonics in the Sierra Nevada (Betic Cordillera, SE Spain): Insights from geomorphic indexes and drainage pattern analysis. Geomorphology 119: 74-87. https://doi.org/10.1016/j.geo morph.2010.1002.1020.

Pérouse E, Chamot-Rooke N, Rabaute A, Briole P, Jouanne F, Georgiev I, et al. 2012. Bridging onshore and offshore present-day kinematics of central and eastern Mediterranean: Implications for crustal dynamics and mantle flow. Geochem Geophys Geosyst 13: Q09013. https://doi.org/10.01029/02012GC004289.

Petri B, Mohn G, Skrzypek E, Mateeva T, Galster F, Manatschal G. 2017. U-Pb geochronology of the Sondalo gabbroic complex (Central Alps) and its position within the Permian post-Variscan extension. Int J Earth Sci (Geol Rundsch) 106: 2873-2893. https:// doi.org/10.1007/s00531-00017-01465-x.

Piana Agostinetti N, Faccenna C. 2018. Deep structure of Northern Apennines subduction orogen (Italy) as revealed by a joint interpretation of passive and active seismic data. Geophysical Research Letters 45: 4017-4024. https://doi.org/10.1029/ 2018GL077640.

Platt JP. 1993. Exhumation of high-pressure rocks: a review of concept and processes. Terra Nova 5: 119-133.

Platt JP, Vissers RLM. 1989. Extensional collapse of thickened continental lithosphere: A working hypothesis for the Alboran Sea and Gibraltar arc. Geology 17: 540-543.

Platt JP, Allerton S, Kirker A, Mandeville C, Mayfield A, Platzman ES, et al. 2003a. The ultimate arc: differential displacement, oroclinal bending, and vertical axis rotation in the external BeticRif arc. Tectonics 22: 1017. https://doi.org/10.1029/ 2001 TC001321.

Platt JP, Anczkiewicz R, Soto JI, Kelley SP, Thirlwall M. 2006. Early Miocene continental subduction and rapid exhumation in the Western Mediterranean. Geology 34: 981-984. https://doi.org/ 10.1130/G22801A.22801.

Platt JP, Behr WM, Johanesen K, Williams JR. 2013. The Betic-Rif Arc and Its Orogenic Hinterland: A Review. Annu Rev Earth Planet Sci 41: 313-357. https://doi.org/10.1146/annurev-earth050212-123951.

Platt JP, Kelley SP, Carter A, Orozco M. 2005. Timing of tectonic events in the Alpujarride Complex, Betic Cordillera, S. Spain. Journal of the Geological Society, London 162: 1-12.

Platt JP, Whitehouse MJ, Kelley SP, Carter A, Hollick L. 2003b. Simultaneous extension exhumation across the Alboran Basin: implications for the causes of late orogenic extension. Geology 31: 251-254. 
Prada M, Sallares V, Ranero CR, Vendrell MG, Grevemeyer I, Zitellini N, et al. 2014. Seismic structure of the Central Tyrrhenian basin: Geophysical constraints on the nature of the main crustal domains. J Geophys Res Solid Earth 119: 52-70. https://doi.org/ 10.1002/2013JB010527.

Prada M, Sallares V, Ranero CR, Vendrell MG, Grevemeyer I, Zitellini $\mathrm{N}$, et al. 2018. Spatial variations of magmatic crustal accretion duringtheopeningoftheTyrrhenianback-arcfrom wide-angle seismic velocity models and seismic reflection images. Basin Research 30: 124-141. https://doi.org/10.1111/bre.12211.

Puigdefabregas C, Souquet P. 1986. Tectosedimentary cycles and depositional sequences of the Mesozoic and Tertiary from the Pyrenees. Tectonophysics 129: 173-203. https://doi.org/10.1016/ 0040-1951(1086)90251-90259.

Quintana L, Pulgar JA, Alonso JL. 2015. Displacement transfer from borders to interior of a plate: A crustal transect of Iberia. Tectonophysics 663: 378-398. https://doi.org/10.1016/j. tecto.2015.1008.1046.

Rat J, Mouthereau F, Brichau S, Crémades A, Bernet M, Balvay M. 2019. Tectonothermal evolution of the Cameros basin: Implications for tectonics of North Iberia. Tectonics 38: 440-469. https://doi. org/10.1029/2018TC005294.

Ravier J. 1959. Le métamorphisme des terrains secondaires des Pyrénées. Mem Soc Geol Fr XXXVIII: 250.

Réhault JP, Boillot G, Mauffret A. 1984. The Western Mediterranean basin geological evolution. Marine Geology 5: 447-477.

Réhault JP, Honthaas C, Guennoc P, Bellon H, Ruffet G, Cotten J, et al. 2012. Offshore Oligo-Miocene volcanic fields within the Corsica-Liguria Basin: Magmatic diversity and slab evolution in the western Mediterranean Sea. Journal of Geodynamics 58: 7395. https://doi.org/10.1016/j.jog.2012.1002.1003.

Réhault JP, Moussat E, Fabbri A. 1987. Structural evolution of the tyrrhenian back-arc basin. Mar Geol 74: 123-150.

Reilinger R, McClusky S, Paradissis D, Ergintav S, Vernant P. 2010. Geodetic constraints on the tectonic evolution of the Aegean region and strain accumulation along the Hellenic subduction zone. Tectonophysics 488: 22-30.

Reilinger R, McClusky S, Vernant P, Lawrence S, Ergintav S, Cakmak $\mathrm{R}$, et al. 2006. GPS constraints on continental deformation in the Africa-Arabia- Eurasia continental collision zone and implications for the dynamics of plate interactions. J Geophys Res 111: B05411. https://doi.org/10.01029/02005JB004051.

Ricard Y, Vigny C. 1989. Mantle dynamics with induced plate tectonics. J Geophys Res 94: 17543-17559.

Ricard Y, Vigny C, Froidevaux C. 1989. Mantle heterogeneities, geoid and plate motions. J Geophys Res 94: 13739-13754.

Ricou LE. 1994. Tethys reconstructed: plates, continental fragments and their boundaries since $260 \mathrm{Ma}$ from Central America to southeastern Asie. Geodinamica Acta 7: 169-218.

Ricou LE, Dercourt J, Geyssant J, Grandjacquet C, Lepvrier C, BijuDuval B. 1986. Geological constraints on the Alpine evolution of the Mediterranean Tethys. Tectonophysics 123: 83-122.

Ring U, Glodny J, Will T, Thomson S. 2010. The Hellenic Subduction System: High-Pressure Metamorphism, Exhumation, Normal Faulting, and Large-Scale Extension. Annu Rev Earth Planet Sci 38: 45-76. https://doi.org/10.1146/annurev.earth.050708.170910.

Roca E, Guimerà J. 1992. The Neogene structure of the eastern Iberian margin: structural constraints on the crustal evolution of the Valencia trough (western Mediterranean). Tectonophysics 203: 203-218.

Rohais S, Eschard R, Ford M, Guillocheau F, Moretti I. 2007. Stratigraphic architecture of the Plio-Pleistocene infill of the
Corinth Rift, implications for its structural evolution. Tectonophysics 440: 5-28.

Rollet N, Déverchère J, Beslier MO, Guennoc P, Réhault JP, Sosson $\mathrm{M}$, et al. 2002. Back-arc extension, tectonic inheritance and volcanism in the Ligurian Sea, western Mediterranean. Tectonics 21: 10.1029 .

Romagny A, Jolivet L, Menant A, Bessière E, Maillard A, Canva A, Thinon I. 2020. Detailed tectonic reconstructions of the Western Mediterranean region for the last $35 \mathrm{Ma}$, insights on driving mechanisms. BSGF - Earth Sciences Bulletin 191: 37. https://doi. org $/ 10.1051 / \mathrm{bsgf} / 2020040$.

Rosenbaum G, Lister GS, Duboz C. 2002a. Reconstruction of the tectonic evolution of the western Mediterranean since the Oligocene. Journal of the Virtual Explorer 8: 107-126.

Rosenbaum G, Lister GS, Duboz C. 2002b. Relative motions of Africa, Iberia and Europe during Alpine orogeny. Tectonophysics 359: 117-129.

Rossetti F, Faccenna C, Goffé B, Monié P, Argentieri A, Funiciello R, et al. 2001. Alpine structural and metamorphic signature of the Sila Piccola massif nappe stack (Calabria, Italy): insights for the tectonic evolution of the Calabrian arc. Tectonics 20: 112-133.

Rossetti F, Faccenna C, Jolivet L, Funiciello R. 1999a. Structural evolution of the Giglio island, Northern Tyrrhenian Sea (Italy). Mem Soc Geol It 52: 493-512.

Rossetti F, Faccenna C, Jolivet L, Funiciello R, Goffé B, Tecce F, et al. 1999b. Structural signature and exhumation P-T-t path of the Gorgona blueschist sequence (Tuscan Archipelago, Italy). Ofioliti 26: $175-186$.

Rossetti F, Goffé B, Monié P, Faccenna C, Vignaroli G. 2004. Alpine orogenic P-T-t-deformation history of the Catena Costiera area and surrounding regions (Calabrian Arc, southern Italy): the nappe edifice of north Calabria revised with insights on the TyrrhenianApennine system formation. Tectonics 23. https://doi.org/10.1029/ 2003TC001560.

Rougier G, Ford M, Christophoul F, Bader AG. 2016. Stratigraphic and tectonic studies in the central Aquitaine Basin, northern Pyrenees: Constraints on the subsidence and deformation history of a retro-foreland basin. C R Geosci 348: 224-235.

Roure F, Choukroune P, Berastegui X, Munoz JA, Villien A, Matheron $\mathrm{P}$, et al. 1989. ECORS deep seismic data and balanced cross sections; geometric constraints on the evolution of the Pyrenees. Tectonics 8: 41-50.

Roure F, Choukroune P, Polino R. 1996. Deep seismic reflection data and new insights on the bulk geometry of mountain ranges. $C R$ Acad Sci Paris 322: 345-359.

Royden L, Patacca E, Scandone P. 1987. Segmentation and configuration of subducted lithosphere in Italy: an important control on thrust-belt and foredeep-basin evolution. Geology 15: 714-717.

Royden LH. 1993. Evolution of retreating subduction boundaries formed during continental collision. Tectonics 12: 629-638.

Royden LH, Burchfiel BC, van der Hilst RD. 2008. The geological evolution of the Tibetan Plateau. Science 321: 1054-1058. https:// doi.org/10.1126/science.1155371.

Rubatto D, Gebauer D, Compagnoni R. 1997. Dating the UHP/HP metamorphism in the Western Alps (Sesia Lanzo and Zermatt Saas Fee): evidence for subduction events at the CreaceousTertiary boundary and in the middle Eocene. Terra Nova 9: 30-31.

Ryan WBF, Carbotte SM, Coplan JO, O'Hara S, Melkonian A, Arko R, et al. 2009. Global Multi-Resolution Topography synthesis. Geochem Geophys Geosyst 10: Q01005. https://doi.org/10.01029/ $02003 \mathrm{GC} 000614$. 
Salas R, Casas A. 1993. Mesozoic extensional tectonics, stratigraphy and crustal evolution during the Alpine cycle of the eastern Iberian basin. Tectonophysics 228: 33-55. https://doi.org/10.1016/ 0040-1951(1093)90213-90214.

Salas R, Guimerà J, Mas R, Martín-Closas C, Melendez A, Alonso A. 2001. Evolution of the Mesozoic central Iberian rift system and its Cainozoic inversion (Iberian chain). Memoires $d u$ Museum National d'Histoire Naturelle 186: 145-186.

Salimbeni S, Malusà MG, Zhao L, Guillot S, Pondrelli S, Margheriti $\mathrm{L}$, et al. 2018. Active and fossil mantle flows in the western Alpine region unravelled by seismic anisotropy analysis and highresolution $\mathrm{P}$ wave tomography. Tectonophysics 731-732: 35-47. https://doi.org/10.1016/j.tecto.2018.1003.1002.

Sanz de Galdeano C, Vera JA. 1992. Stratigraphic record and paleogeographical context of the Neogene basins in the Betic Cordillera, Spain. Basin Research 4: 21-36.

Sartori R, Torelli L, Zitellini N, Carrara G, Magaldi M, Mussoni P. 2004. Crustal features along a W-E Tyrrhenian transect from Sardinia to Campania margins (Central Mediterranean). Tectonophysics 383: 171-192.

Saspiturry N, Cochelin B, Razin P, Leleu S, Lemire B, Bouscary C, et al. 2019. Tectono-sedimentary evolution of a rift system controlled by Permian post-orogenic extension and metamorphic core complex formation (Bidarray basin and Ursuya dome, Western Pyrenees). Tectonophysics 768: 228180.

Saspiturry N, Lahfid A, Baudin T, Guillou-Frottier L, Razin P, Issautier B, et al. 2020. Paleogeothermal gradients across an inverted hyperextended rift system: Example of the Mauléon fossil rift (Western Pyrenees). Tectonics 39: e2020TC006206. https://doi. org/10.001029/002020TC006206.

Saspiturry N, Razin P, Baudin T, Serrano O, Issautier B, Lasseur E, et al. 2019. Symmetry vs. asymmetry of a hyper-thinned rift: Example of the Mauléon Basin (Western Pyrenees, France). Marine and Petroleum Geology 104: 86-105. https://doi.org/ 10.1016/j.marpetgeo.2019.1003.1031.

Schettino A, Scotese C. 2002. Global kinematic constraints to the tectonic history of the Mediterranean region and surrounding areas during the Jurassic and Cretaceous. In: Rosenbaum G, Lister GS, eds. Reconstruction of the evolution of the Alpine-Himalayan orogen. Journal of the Virtual Explorer: 149-168.

Schettino A, Turco E. 2006. Plate kinematics of the Western Mediterranean region during the Oligocene and Early Miocene. Geophys J Int 166: 1398-1423. https://doi.org/10.1111/ j.1365-1246X.2006.02997.x.

Schildgen TF, Y1ldırım C, Cosentino D, Strecker MR. 2014. Linking slab break-off, Hellenic trench retreat, and uplift of the Central and Eastern Anatolian plateaus. Earth-Science Reviews 128: 147-168. https://doi.org/10.1016/j.earscirev.2013.1011.1006.

Schmid SM, Bernoulli D, Fügenschuh B, Matenco L, Schefer S, Schuster R, et al. 2008. The Alpine-Carpathian-Dinaridic orogenic system: correlation and evolution of tectonic units. Swiss J Geosci 101: 139-183. https://doi.org/10.1007/s00015-0000801247-00013.

Schmid SM, Fügenschuh B, Kissling E, Schuster R. 2004. Tectonic map and overall architecture of the alpine orogen. Eclog Geol Helv 97: 93-117.

Schmid SM, Kissling E, van Hinsbergen TDJJ, Molli G. 2017. Ivrea mantle wedge, arc of the Western Alps, and kinematic evolution of the Alps-Apennines orogenic system. Swiss J Geosci 110: 581612. https://doi.org/10.1007/s00015-00016-00237-00010.

Schmid SM, Pffifner OA, Schönborg G, Froitzheim N, Kissling E. 1997. Integrated cross-sections and tectonic evolution of the Alps along the Eastern Traverse. In: Pffifner OA, Lehner P, Heitzmann P,
Mueller S, Steck A, eds. Deep structures of the Swiss Alps. Basel: Birkhäuser, pp. 289-304.

Séranne M. 1999. The Gulf of Lions continental margin (NW Mediterranean) revisited by IBS: an overview. In: Durand B, Jolivet L, Horvàth F, Séranne M, eds. The Mediterranean basins: Tertiary extension within the Alpine Orogen. London: Geological Society, pp. 15-36.

Séranne M, Benedicto A, Truffert C, Pascal G, Labaume P. 1995. Structural style and evolution of the Gulf of Lion Oligo-Miocene rif ting: Role of the Pyrenean orogeny. Marine and Petroleum Geology 12: 809-820.

Séranne M, Couëffé R, Husson E, Villard J. 2021. The transition from Pyrenean shortening to Gulf of Lion rifting in Languedoc (South France) - A tectonic-sedimentation analysis. BSGF - Earth Sciences Bulletin 192: 27. https://doi.org/10.1051/bsgf/2021017.

Serpelloni E, Vannucci G, Pondrelli S, Argnani A, Casula G, Anzidei M, et al. 2007. Kinematics of the Western Africa-Eurasia plate boundary from focal mechanisms and GPS data. Geophys J Int 169: 1180-1200. https://doi.org/10.1111/j.1365-1246X.2007.03367.x.

Sibuet JC, Srivastava SP, Spakman W. 2004. Pyrenean orogeny and plate kinematics. Journal of Geophysical Research: Solid Earth 109: 1-18. https://doi.org/10.1029/2003JB002514.

Sinclair HD, Gibson M, Naylor M, Morris RG. 2005. Asymmetric growth of the Pyrenees revealed through measurement and modeling of orogenic fluxes. American Journal of Science 305: 369-406. https://doi.org/10.2475/ajs.2305.2475.2369.

Soares D, Alves T, Terrinha P. 2012. The breakup sequence and associated lithospheric breakup surface: Their significance in the context of rifted continental margins (West Iberia and Newfoundland margins, North Atlantic). Earth and Planetary Science Letters 355-356: 311-326. https://doi.org/10.1016/j.epsl.2012.1008.1036.

Soumaya A, Ben Ayed N, Rajabi M, Meghraoui M, Delvaux D, Kadri A, et al. 2018. Active faulting geometry and stress pattern near complex strike-slip systems along the Maghreb region: Constraints on active convergence in the western Mediterranean. Tectonics 37: 3148-3173. https://doi.org/10.1029/2018TC004983.

Souriau A, Rigo A, Sylvander M, Benahmed S, Grimaud F. 2014. Seismicity in central-western Pyrenees (France): A consequence of the subsidence of dense exhumed bodies. Tectonophysics 621: 123131. https://doi.org/10.1016/j.tecto.2014.1002.1008.

Spakman W, Chertova MV, van den Berg A, van Hinsbergen DJJ. 2018. Puzzling features of western Mediterranean tectonics explained by slab dragging. Nature Geoscience 11: 211-216. https://doi.org/10.1038/s41561-41018-40066-z.

Spakman W, Wortel R. 2004. A tomographic view on Western Mediterranean geodynamics. In: Cavazza W, Roure FM, Spakman W, Stampfli GM, Ziegler PA, eds. The TRANSMED Atlas - The Mediterranean region from crust to Mantle. Berlin, Heidelberg: Springer, pp. 31-52.

Stampfli GM, Borel GD. 2002. A plate tectonic model for the Paleozoic and Mesozoic constrained by dynamic plate boundaries and restored synthetic oceanic isochrons. Earth Planet Sci Lett 196: $17-33$.

Steinberger B, Torsvik TH. 2008. Absolute plate motions and true polar wander in the absence of hotspot tracks. Nature 452: 620-623.

Sternai P, Avouac JP, Jolivet L, Faccenna C, Gerya T, Becker TW, et al. 2016. On the influence of the asthenospheric flow on the tectonics and topography at a collision-subduction transition zones: comparison with the eastern Tibetan margin. Journal of Geodynamics 100: 184-197. https://doi.org/10.1016/j. jog.2016.1002.1009.

Sternai P, Jolivet L, Menant A, Gerya T. 2014. Subduction and mantle flow driving surface deformation in the Aegean-Anatolian system. 
Earth Planet Sci Lett 405: 110-118. https://doi.org/10.1016/j. eps1.2014.1008.1023.

Sternai P, Sue C, Husson L, Serpelloni E, Becker TW, Willett SD, et al. 2019. Present-day uplift of the European Alps: Evaluating mechanisms and models of their relative contributions. Earth Science Reviews. https://doi.org/10.1016/j.ear scirev.2019.1001.1005.

Stich D, Serpelloni E, de Lis Mancilla F, Morales J. 2006. Kinematics of the Iberia-Maghreb plate contact from seismic moment tensors and GPS observations. Tectonophysics 426: 295-317.

Stoddard PR, Abbott D. 1996. Influence of the tectosphere upon plate motion. J Geophys Res 101: 5425-5433.

Strzerzynski P, Déverchère J, Cattaneo A, Domzig A, Yelles K, Mercier de Lépinay B, et al. 2010. Tectonic inheritance and Pliocene-Pleistocene inversion of the Algerian margin around Algiers: Insights from multibeam and seismic reflection data. Tectonics 29: TC2008. https://doi.org/10.1029/2009TC002547.

Strzerzynski P, Dominguez S, Boudiaf A, Déverchère J. 2021. Tectonic inversion and geomorphic evolution of the Algerian margin since Messinian times: Insights from new onshore/offshore analog modeling experiments. Tectonics 40: e2020TC006369. https://doi.org/10.001029/002020TC006369.

Sue C, Tricart P. 1999. Late alpine brittle extension above the Frontal Penninic Thrust near Briançon, western Alps. Eclogae Geol Helv 92: 171-181.

Sue C, Thouvenot F, Fréchet J, Tricart P. 1999. Widespread extension in the core of the western Alps revealed by earthquake analysis. $J$ Geophys Res 104: 25611-25622.

Tapponnier P, Molnar P. 1976. Slip line field theory and large-scale continental tectonics. Nature 264: 319-324.

Tapponnier P, Zhiqin X, Roger F, Meyer B, Arnaud N, Wittlinger G, et al. 2001. Oblique stepwise Rise and growth of the Tibet plateau. Science 294: 1671-1677.

Tavani S, Bertok C, Granado P, Piana F, Salas R, Vigna B, et al. 2018. The Iberia-Eurasia plate boundary east of the Pyrenees. EarthScience Reviews 187: 314-337. https://doi.org/10.1016/j.ear scirev.2018.1010.1008.

Taylor B, Weiss J, Goodliffe A, Sachpazi M, Laigle M, Hirn A. 2011. The structures, stratigraphy and evolution of the Gulf of Corinth rift, Greece. Geophys J Int 185: 1189-1219. https://doi.org/ 10.1111/j.1365-1246X.2011.05014.x.

Teixell A, Labaume P, Ayarza P, Espurt N, de Saint Blanquat M, Lagabrielle Y. 2018. Crustal structure and evolution of the Pyrenean-Cantabrian belt: A review and new interpretations from recent concepts and data. Tectonophysics 724-725: 146-170. https://doi.org/10.1016/j.tecto.2018.1001.1009.

Ternois S, Mouthereau F, Jourdon A. 2021. Decoding lowtemperature thermochronology signals in Alpine-type orogens: modelling the role of rift thermal imprint into continental collision. BSGF - Earth Sciences Bulletin 192: 38. https://doi.org/10.1051/ bsgf/2021028.

Ternois S, Odlum M, Ford M, Pik R, Stockli D, Tibari B, et al. 2019. Thermochronological evidence of early orogenesis, eastern Pyrenees, France. Tectonics 38: 1308-1336. https://doi.org/ 10.1029/2018TC005254.

Tugend J, Chamot-Rooke N, Arsenikos S, Blanpied C, Frizon de Lamotte D. 2019. Geology of the Ionian Basin and margins: A key to the East Mediterranean geodynamics. Tectonics 38. https://doi. org/10.1029/2018TC005472.

Tugend J, Manatschal G, Kusznir NJ, Masini E, Mohn G, Thinon I. 2014. Formation and deformation of hyperextended rift systems: Insights from rift domain mapping in the Bay of Biscay- Pyrenees. Tectonics 33: 1239-1276. https://doi.org/10.1002/2014TC003529.
Uyeda S, Kanamori H. 1979. Backarc opening and the mode of subduction. J Geophys Res 84: 1049-1106.

Vacherat A, Mouthereau F, Pik R, Huyghe D, Paquette JL, Christophoul F, et al. 2017. Rift-to-collision sediment routing in the Pyrenees: A synthesis from sedimentolo- gical, geochronological and kinematic constraints. Earth-Science Reviews 172: 43-74. https://doi.org/10.1016/j.earscirev.2017.1007.1004.

van der Meulen MJ, Meulenkamp JE, Wortel MJR. 1998. Lateral shifts of Apenninic foredeep depocentres reflecting detachment of subducted lithosphere. Earth Planet Sci Lett 154: 201-218.

van Hinsbergen DJJ, Hafkenscheid E, Spakman W, Meulenkamp JE, Wortel R. 2005. Nappe stacking resulting from subduction of oceanic and continental lithosphere below Greece. Geology 33: 325-328. https://doi.org/10.1130/G20878.20871.

van Hinsbergen DJJ, Torsvik TH, Schmid SM, Maţenco LC, Maffione M, Vissers RLM, et al. 2019. Orogenic architecture of the Mediterranean region and kinematic reconstruction of its tectonic evolution since the Triassic. Gondwana Research 81: 79-229. https://doi.org/10.1016/j.gr.2019.1007.1009 (in press).

van Hinsbergen DJJ, Vissers RLM, Spakman W. 2014. Origin and consequences of western Mediterranean subduction, rollback, and slab segmentation. Tectonics 33: 393-419. https://doi.org/10.1002/ tect.20125.

Vaughan APM, Scarrow JH. 2003. Ophiolite obduction pulses as a proxy indicator of superplume events? Earth and Planetary Science Letters 213: 407-416. https://doi.org/10.1016/ S0012-1821X(1003)00330-00333.

Vergés J, Fernandez M, Martinez A. 2002. The Pyrenean orogen: pre-, syn-, and post-collisional evolution. In: Rosenbaum G, Lister GS, eds. Reconstruction of the evolution of the Alpine-Himalayan orogen. pp. 57-76.

Vergés J, Garcia-Senz J. 2001. Mesozoic evolution and Cainozoic inversion of the Pyrenean rift in: Peri-Tethys Memoir 6: PeriTethyan rift/wrench basins and passive margins. In: Ziegler PA, et al., eds Mémoires du Muséum National d'Histoire Naturelle. Paris: Museum National d'Histoire Naturelle, pp. 187-212.

Vergés J, Millan H, Roca E, Muñoz JA, Marzo M, Den Bezemer T, et al. 1995. Eastern Pyrenees and related foreland basins: pre-, synand post-collisional crustal-scale cross-sections. Marine and Petroleum Geology 12: 893-915.

Vially R, Tremolières P. 1996. Geodynamics of the Gulf of Lions: implications for petroleum exploration. In: Ziegler $\mathrm{P}$, Horvàth $\mathrm{F}$, eds. Peri-Tethys Memoir 2: Structure and propects of alpine basins and forelands. Paris, pp. 129-158.

Vielzeuf D, Kornprobst J. 1984. Crustal splitting and the emplacement of Pyrenean lherzolites and granulites. Earth Planet Sci Lett 67: 87-96.

Vignaroli G, Faccenna C, Jolivet L, Piromallo C, Rossetti F. 2008. Orogen-parallel extension and arc bending forced by slab tearing and toroidal flow at the junction between Alps and Apennines. Tectonophysics 450: 34-50. https://doi.org/10.1016/j. tecto.2007.1012.1012.

Vignaroli G, Faccenna C, Rossetti F, Jolivet L. 2009. Insights from the apennines metamorphic complexes and their bearing on the kinematics evolution of the orogen. In: van Hinsbergen DJJ, Edwards MA, Govers R, eds. Collision and collapse at the AfricaArabia-Eurasia subduction zone. London: The Geological Society, pp. 235-256.

Vissers RLM, Meijer PT. 2012. Mesozoic rotation of Iberia: Subduction in the Pyrenees? Earth-Science Reviews 110: 93-110.

Vissers RLM, Platt JP, Van der Wal D. 1995. Late orogenic extension of the Betic Cordillera and the Alboran domain: a lithospheric view. Tectonics 14: 786-803. 
Vitale-Brovarone A, Herwartz D. 2013. Timing of HP metamorphism in the Schistes Lustrés of Alpine Corsica: New Lu-Hf garnet and lawsonite ages. Lithos 172-173: 175-191. https://doi.org/10.1016/ j.lithos.2013.1003.1009.

Voigt T, Wiese F, von Eynatten H, Franzke HJ, Gaupp R. 2006. Facies evolution of syntectonic Upper Cretaceous deposits in the Subhercynian Cretaceous Basin and adjoining areas (Germany). $Z$ dt Ges Geowiss 157/2: 203-244.

Waldner M, Bellahsen N, Mouthereau F, Bernet M, Pik R, Rosenberg C, et al. 2019. Central Pyrenees mountain building: constraints from new LT thermochronological data from the Axial Zone. Tectonics 40: e2020TC006614. https://doi.org/006610.001029/ 002020TC006614.

Walpersdorf A, Pinget L, Vernant P, Sue C, Deprez A, the RENAG Team. 2018. Does long-term GPS in the Western Alps finally confirm earthquake mechanisms? Tectonics 37: 3721-3737. https:// doi.org/10.1029/2018TC005054.

Wang Y, Chevrot S, Monteiller V, Komatitsch D, Mouthereau F, Manatschal G, et al. 2016. The deep roots of the western Pyrenees revealed by full waveform inversion of teleseismic $\mathrm{P}$ waves. Geology 44: 475-478. https://doi.org/10.1130/G37812.37811.

Wehr H, Chevrot S, Courrioux G, Guillen A. 2018. A threedimensional model of the Pyrenees and their foreland basins from geological and gravimetric data. Tectonophysics 734-735: 16-32. https://doi.org/10.1016/j.tecto.2018.1003.1017.

Weijermars R, Roep TB, Van den Eeckhout B, Postma G, Kleverlaan K. 1985. Uplift history of a Betic fold nappe inferred from Neogene-Quaternary sedimentation and tectonics (in the Sierra Alhamilla and Almería, Sorbas and Tabernas Basins of the Betic Cordilleras, SE Spain). Geol en Mijnbouw 64: 397-411.

White R, McKenzie D. 1989. Magmatism at rift zones: the generation of volcanic continental margins and flood basalts. J Geophys Res 94: 7685-7729.

Wicker V, Ford P. 2021. Salt tectonics in the Toulon Belt: inversion of a salt-rich fault zone. BSGF - Earth Sciences Bulletin 200059. https://doi.org/10.1051/bsgf/2021033.

Wijbrans JR, McDougall I. 1988. Metamorphic evolution of the Attic Cycladic Metamorphic Belt on Naxos (Cyclades, Greece) utilizing
40Ar/39Ar age spectrum measurements. J Metamorph Geol 6: 571-594. https://doi.org/10.1111/j.1525-1314.1988.tb00441.x.

Wijbrans JR, van Wees JD, Stephenson RA, Cloethingh SAPL. 1993. Pressure-temperature-time evolution of the high-pressure metamorphic complex of Sifnos, Greece. Geology 21: 443-446.

Wortel MJR, Spakman W. 1992. Structure and dynamic of subducted lithosphere in the Mediterranean. Proc Kon Ned Akad v Wetensch 95: 325-347.

Wortel MJR, Spakman W. 2000. Subduction and slab detachment in the Mediterranean-Carpathian region. Science 290: 1910-1917.

Yelles A, Domzig A, Déverchère J, Bracène R, Mercier de Lépinay B, Strzerzynski P, et al. 2009. Plio-Quaternary reactivation of the Neogene margin off NW Algiers, Algeria: The Khayr al Din bank. Tectonophysics 475: 98-116. https://doi.org/10.1016/j. tecto.2008.1011.1030.

Yin A. 2010. Cenozoic tectonic evolution of Asia: A preliminary synthesis. Tectonophysics 488: 293-325. https://doi.org/10.1016/j. tecto.2009.1006.1002.

Ziegler PA. 1988. Evolution of the Arctic-North Atlantic and the Western Tethys. Am Assoc Petrol Geol Mem 43: 198 p.

Ziegler PA. 1990. Geological Atlas of Western and Central Europe. Shell Internat. Bath: Petrol Mij Dist Geol Soc Publ House.

Ziegler P. 1999. Evolution of the Arctic-North Atlantic and the Western Tethys. AAPG Memoir 43: 164-196.

Ziegler PA, Dèzes P. 2007. Cenozoic uplift of Variscan Massifs in the Alpine foreland: Timing and controlling mechanisms. Global and Planetary Change 58: 237-269. https://doi.org/10.1016/j.glopla cha.2006.1012.1004.

Zeyen H, Ayarza P, Fernàndez M, Rimi A. 2005. Lithospheric structure under the western African-European plate boundary: A transect across the Atlas Mountains and the Gulf of Cadiz. Tectonics 24: TC2001. https://doi.org/10.1029/2004TC001639.

Zitellini N, Ranero CR, Loreto MF, Ligi M, Pastore M, D’Oriano P, et al. 2019. Recent inversion of the Tyrrhenian Basin. Geology 48: 123-127. https://doi.org/10.1130/G46774.46771.

Zoback ML. 1992. First- and second-order patterns of stress in the lithosphere: the world stress map project. $J$ Geophys Res 97: 11703-11728.

Cite this article as: Jolivet L, Baudin T, Calassou S, Chevrot S, Ford M, Issautier B, Lasseur E, Masini E, Manatschal G, Mouthereau F, Thinon I, Vidal O. 2021. Geodynamic evolution of a wide plate boundary in the Western Mediterranean, near-field versus far-field interactions, BSGF - Earth Sciences Bulletin 192: 48. 